\title{
Exploring the role of education in a MIRAB economy: brain drain or brain gain?
}

\section{The case of Wallis and Futuna}

\section{Alice Caroline Jacobs}

A thesis submitted to Victoria University of Wellington in partial fulfillment of requirements for the degree of Master of Development Studies

School of Geography, Environment and Earth Sciences

Victoria University of Wellington

2016 


\section{Table of Contents}

ABSTRACT IV

ACKNOWLEDGEMENTS VI

$\begin{array}{ll}\text { TABLE OF FIGURES } & \text { VII }\end{array}$

$\begin{array}{ll}\text { ACRONYMS } & \text { VII }\end{array}$

GLOSSARY VIII

CHAPTER ONE: INTRODUCTION AND CONTEXT

1.1. INTRODUCTION 2

1.2. RESEARCH FRAMEWORK 3

1.3. THE MIRAB MODEL 5

$\begin{array}{ll}1.3 & \text { WALLIS AND FUTUNA } \\ 10\end{array}$

1.3.1. GEOGRAPHICAL OVERVIEW

1.3.2. SincE THE STATUTE

1.4.3 MigRATION FROM WALLIS AND FUTUNA 20

1.4. THESIS RATIONALE AND QUESTIONS 23

1.5. THESIS OUTLINE 24

CHAPTER TWO: MIGRATION, EDUCATION AND DEVELOPMENT IN THE LITERATURE $\quad 25$

$\begin{array}{llr}2.1 & \text { INTRODUCTION } & 26\end{array}$

2.2 THE GLOBAL CONTEXT OF MIGRATION 26

$\begin{array}{lll}\text { 2.2.1 } & \text { MIGRATION AND DEVELOPMENT } & 26\end{array}$

2.2.2 BRAIN CIRCULATION 28

2.3 SMAll STATES, THE PaCific AND MigRation 31

$\begin{array}{lll}2.3 .1 & \text { A CULTURE OF MigRATION } & 31\end{array}$

2.3.2 BRAIN CIRCULATION 33

2.4 TO INCREASE RETURN OR CONTROL EMIGRATION? 36

\begin{tabular}{ll}
2.5 & REVIEWING THE GAPS \\
\hline
\end{tabular}

CHAPTER THREE: METHODOLOGY AND FIELDWORK

$\begin{array}{lll}3.1 & \text { INTRODUCTION } & 44\end{array}$

3.2 METHODS

3.2.1 WORLDVIEW AND RESEARCH APPROACH 44

3.2.2 TALANOA ERROR! BOOKMARK NOT DEFINED.

3.3 IN THE FIELD 46

3.3.1 PARTICIPANTS AND RECRUITMENT $\quad 47$

$\begin{array}{lll}3.3 .2 & \text { CONSENT AND ANONYMITY } & 49\end{array}$

$\begin{array}{ll}3.3 .3 & \text { LANGUAGE } \\ 3.3 .4 & 50\end{array}$

$\begin{array}{lll}3.3 .4 & \text { RECORDING } & 50\end{array}$

3.3.5 TRANSPORT AND ACCOMMODATION 51 
3.4 REFLEXIVITY 51

3.4.1 POSITIONING MYSELF IN THE RESEARCH

3.5 ANALYSIS OF THE RESEARCH

CHAPTER FOUR: EDUCATION, EMPLOYMENT AND CULTURE - INSIGHTS

\begin{tabular}{lr} 
FROM PARTICIPANTS & 57 \\
\hline
\end{tabular}

$\begin{array}{lll}4.1 & \text { INTRODUCTION } & 58\end{array}$

4.2 "WE NEED QUALIFICATIONS HERE”

4.2.1 TRANSFER OF SYSTEM $\quad 59$

4.2.2 HIGH SCHOOL 63

4.2.3 DEGREE CHOICE AND DESTINATION 68

4.2.4 OTHER OPPORTUNITIES FOR EDUCATION 72

4.3 “THERE ARE NO JOBS”

4.3.1 PUBLIC SECTOR

4.3.2 PRIVATE SECTOR AND CREATION UPON RETURN 82

4.4 "EVERYONE HAS THEIR PLACE"

4.4.1 HIERARCHY 90

4.4.2 CUSTOMARY REPRESENTATION 92

4.4.3 PlaCE AND EMPLOYMENT

4.4.4 NETWORKS 96

$\begin{array}{ll}4.4 .5 & \text { CUSTOMARY LAND EMPLOYMENT } \\ & 100\end{array}$

4.4.6 AGE, STATUS AND THE RIGHT TO SPEAK 103

4.5 “TO MAKE THEM RETURN, WE NEED TO HAVE THE STRUCTURES” 107

$\begin{array}{ll}\text { 4.5.1 CHANGE WITHIN THE CONFINES OF THE SYSTEM } & 108\end{array}$

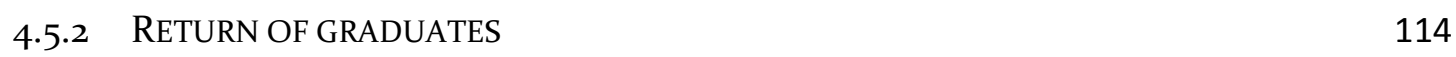

4.5.3 “WE'RE DESTINED TO LIVE ABROAD” 119

$\begin{array}{ll}4.6 & \text { SUMMARY OF FINDINGS } \\ & 125\end{array}$

CHAPTER FIVE: EDUCATION AND THE HINTERLAND 127

$\begin{array}{ll}5.1 \text { INTRODUCTION } & 128\end{array}$

5.2 EdUCATION AND MigRation $\quad 129$

$\begin{array}{lr}5.2 .1 \text { BRAIN DRAIN } & 130\end{array}$

$\begin{array}{ll}\text { 5.2.2 BRAIN GAIN } & 133\end{array}$

5.3 CONTROLLING THE IMPACT OF EDUCATION 136

$\begin{array}{ll}5.4 \text { CONCLUSION } & 141\end{array}$

CHAPTER SIX: A NEW BRAIN GAIN AND A POST-MIRAB ECONOMY 143

\begin{tabular}{lr} 
BIBLIOGRAPHY & 149 \\
\hline
\end{tabular}

\begin{tabular}{ll} 
APPENDICES & 163 \\
\hline
\end{tabular}

$\begin{array}{ll}\text { APPENDIX A } & 163\end{array}$ 
Pursuit of higher education overseas is becoming a common pathway for young Wallisians and Futunans. A constructivist grounded theory study demonstrates that education has provided (i) a new exit route for young people, (ii) an opportunity to access employment overseas and (iii) an opportunity to access employment at home.

Through Talanoa interviews, it was found that the decisions to settle permanently or to return are influenced by cultural, political, economic and structural factors amplified by the slow amalgamation of two conflicting systems. Many students are steered by the French education system and unable to return due to unsuited qualifications. Others choose not to return as a response to underdeveloped structures that constrain the use of qualifications in Wallis and Futuna.

Access to education has seemingly intensified clashes between a 'modern' system based on equality of opportunity and a customary hierarchy where everyone has a place in society. Despite the need for qualifications, access to employment in Wallis and Futuna in practice is dependent on class structures and networks as a result of low employment opportunities and high labour availability.

Yet, evidence of localisation and changing attitudes towards qualifications has suggested a new dimension of the brain gain. Young determined graduates have demonstrated strategic use of resources overseas and adapted new knowledge to the customary and political context.

Access to education has proved to be a key component of the MIRAB society in Wallis and Futuna and a potential catalyst for a new stability, a possible postMIRAB economy.

Key terms: migration, education, development, brain drain, brain gain, MIRAB, Wallis and Futuna 
One summer, I was travelling back to the United Kingdom from Nadi, Fiji. On the flight to Seoul from Nadi, I was sitting next to a woman from Polynesia. We started talking, as she needed help with translating. She was from Wallis and Futuna and was flying to France to visit her four children who were all studying in the metropolis. Meeting her has since stuck with me and ignited my curiosity to discover the territory and look into what education abroad means for the population of these two insular and unique islands in the heart of the South Pacific. 


\section{Acknowledgements}

There are a number of people I would like to express extreme gratitude to for their help during the whole research process.

I would like to first and foremost thank every single one of the participants in this research. This project would not have been able to go forward without your contributions and insights.

I would also like to thank my supervisor John Overton for his guidance and continuous enthusiasm for the project, Gerard Prinsen for sharing his knowledge in Wallis and Futuna, my friends, the 'development studies' group and my family for all the encouragement throughout the year. Big thanks to my other half, Ben Moginie, for being there for me throughout the process. I am extremely grateful to my mother and father for proofreading my work in particular.

I would also like to extend my thanks to everyone in Wallis, Futuna and New Caledonia who fed me, housed me, showed me around the islands or helped me in any way. I had the most amazing couple of months getting to know the French Pacific and was accompanied by great company.

Lastly, I am eternally grateful to John Overton again for the financial support without which this project would not have gone ahead. 


\section{Table of Figures}

Figure 1 Map of the Pacific. Source: Secretariat of the Pacific Community (2016) ........... IX

Figure 2 Population PYRAMID FOR WALLIS AND FUtUNA. SOURCE: IEOM (2015) ....................

FigURE 3 WALLIS AND FUtUNA DISTRICTS. SOURCE: INSEE (2009).....................................13

Figure 4 Division of RESPONSIBILITIES OF THE STATE, CUSTOMARY AUtHORITY AND THE TERRITORIAL

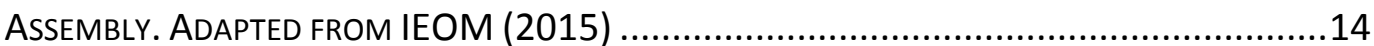

Figure 5 The French educational System. AdaPted from ONISEP (2016) ........................62

Acronyms

\begin{tabular}{|c|c|c|}
\hline ADIE & $\begin{array}{l}\text { Association pour le Droit } \\
\text { à L'Initiative } \\
\text { Economique }\end{array}$ & $\begin{array}{l}\text { Association for the } \\
\text { Right to Economic } \\
\text { Initiative }\end{array}$ \\
\hline BEP & $\begin{array}{l}\text { Brevet d'Etude } \\
\text { Professionnelle }\end{array}$ & Professional Diploma \\
\hline CAP & $\begin{array}{l}\text { Certificat d'Aptitude } \\
\text { Professionnelle }\end{array}$ & $\begin{array}{l}\text { Professional Skill } \\
\text { Certificate (vocational) }\end{array}$ \\
\hline CAPES & $\begin{array}{l}\text { Certificat d'Aptitude au } \\
\text { Professorat de } \\
\text { I'Enseignement du } \\
\text { Second Degré }\end{array}$ & $\begin{array}{l}\text { Secondary School } \\
\text { Teaching Skills } \\
\text { Certificate }\end{array}$ \\
\hline COM & Collectivite d'Outre-Mer & Overseas Collectivity \\
\hline DOM & $\begin{array}{l}\text { Departement d'Outre- } \\
\text { Mer }\end{array}$ & Overseas Department \\
\hline INSEE & $\begin{array}{l}\text { Institut National de la } \\
\text { Statistique et des Etudes } \\
\text { Economique }\end{array}$ & $\begin{array}{l}\text { National Institute of } \\
\text { Statistics and Economic } \\
\text { Studies }\end{array}$ \\
\hline IEOM & $\begin{array}{l}\text { Institut d'Emission } \\
\text { d'Outre-Mer }\end{array}$ & $\begin{array}{l}\text { Institute for overseas } \\
\text { territories }\end{array}$ \\
\hline TOM & Territoire d'Outre-Mer & Overseas Territory \\
\hline
\end{tabular}


Glossary

\begin{tabular}{|l|l|}
\hline Aliki & People with customary authority \\
\hline Administration Superieure & Administration \\
\hline Aga'i fenua & Custom \\
\hline Assemblée Territoriale & Territorial Assembly \\
\hline Autorité Coutumière & Customary Authority \\
\hline Bourse & Bursary \\
\hline Circonscription & District \\
\hline Commission Permanente & Permanent Commission \\
\hline Concours & Competition/interview \\
\hline Conseil Territorial & Territorial board/council \\
\hline Crise Royale & Royal Crisis \\
\hline Elu & Elected (political) \\
\hline Fale & Traditional Housing \\
\hline Fatogia & Customary obligations towards the \\
chiefs
\end{tabular}




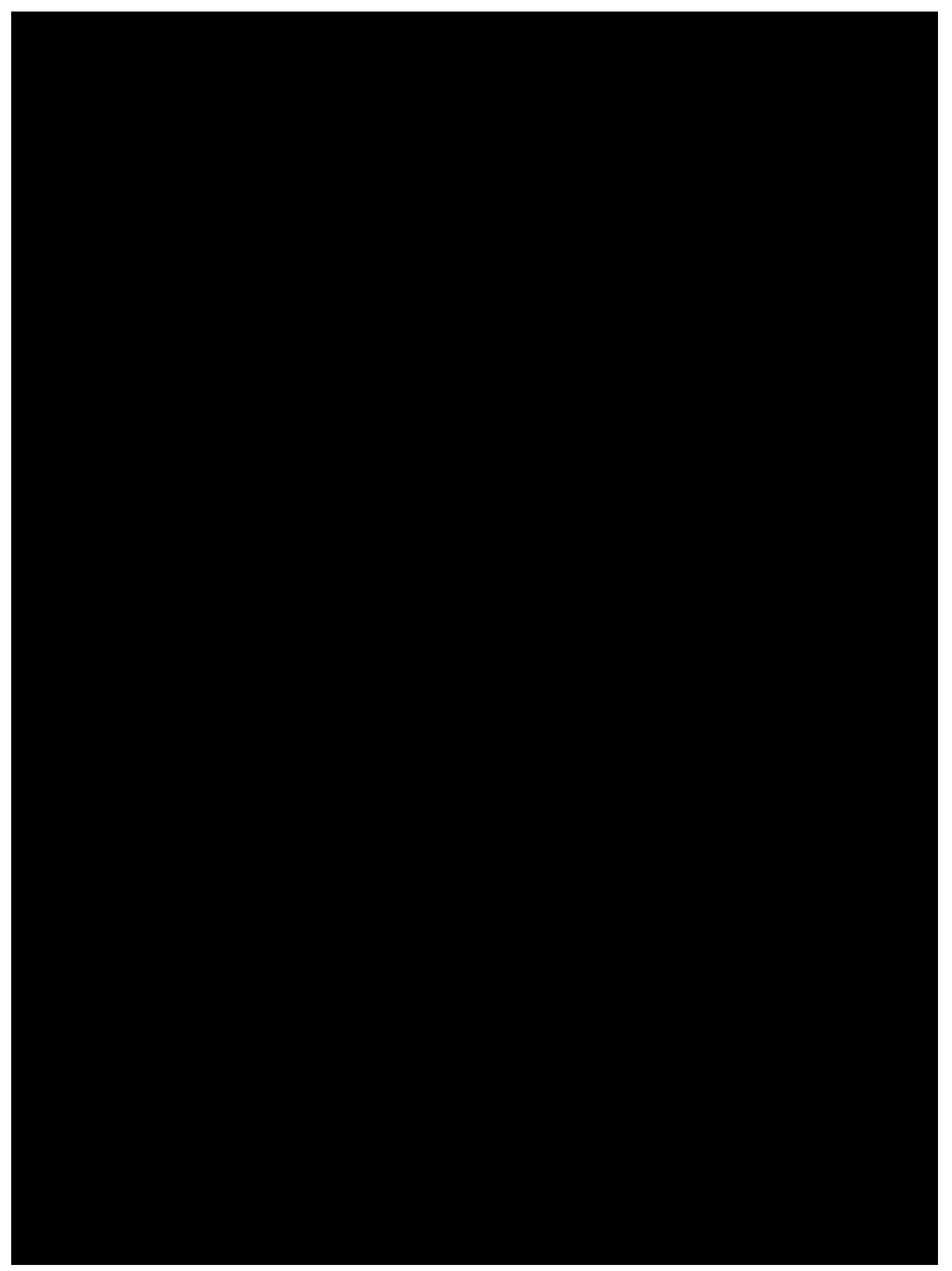




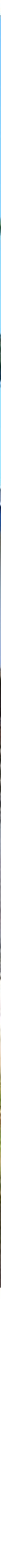




\subsection{Introduction}

Wallis and Futuna, a dependent French insular territory in the heart of the South Pacific, has recently been experiencing severe outmigration and is facing depopulation. Wallis and Futuna has recently been losing a high proportion of its population of working age and INSEE (2009) and IEOM (2015) warn that the lower fertility rates no longer compensate for emigration.

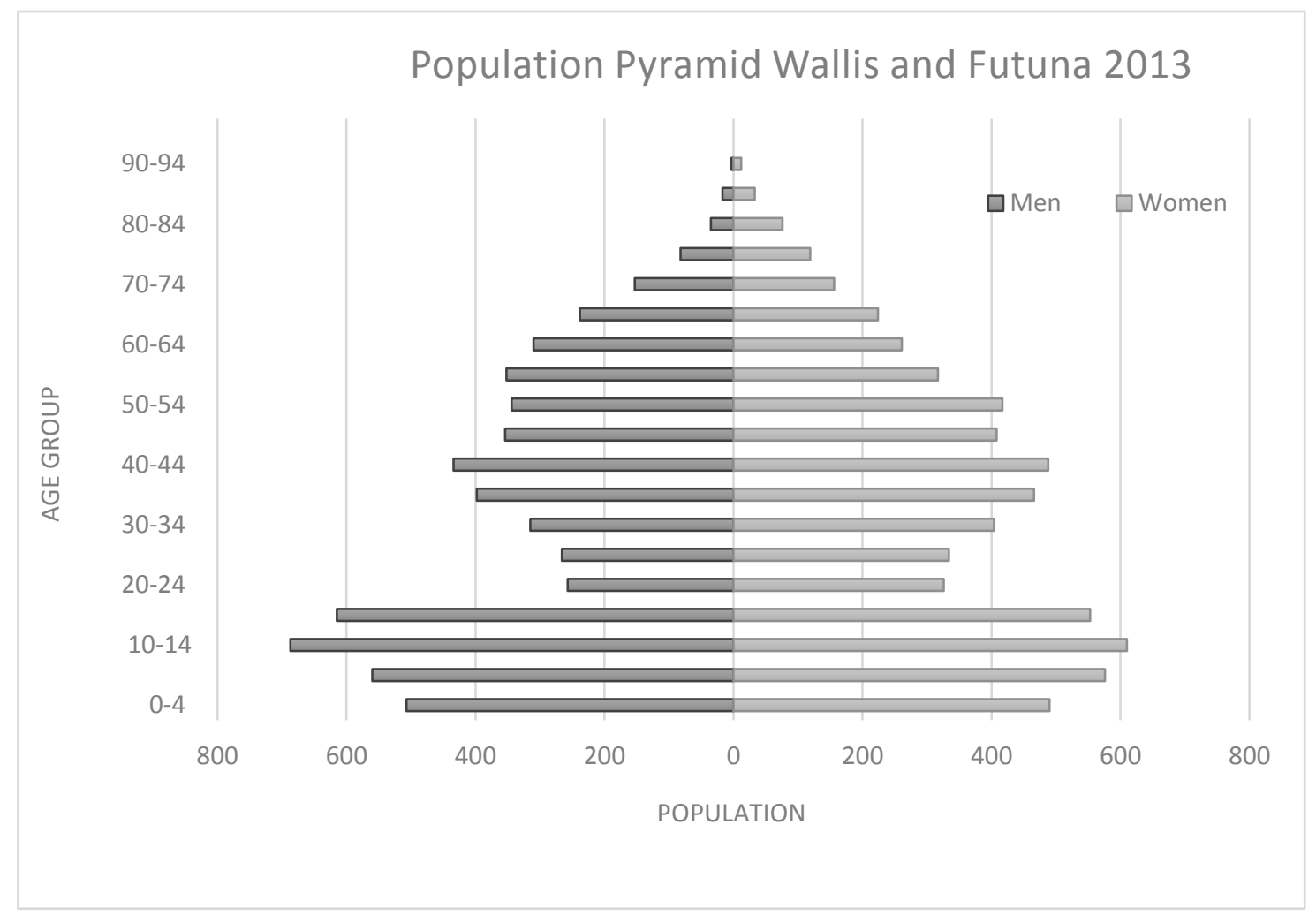

Figure 2 Population pyramid for Wallis and Futuna. Adapted from IEOM (2015) and STSEE

The decreasing population is a constant alarm for the territory and how to address the phenomenon raises an enduring debate.

"An important concern arises from the decreasing population of the young populations in particular, which seems to be accelerating. At the end of 2014, the population 
was estimated at less than 11 thousand inhabitants" 1 (IEOM, 2015, p. 9).

In previous decades, migration from Wallis and Futuna was attributed to employment opportunities offered in New Caledonia (Connell, 1983) but recent migration patterns have shown that a high number of young people are now pursuing higher education opportunities particularly in France, New Caledonia and French Polynesia (Finau et al., 2009, p. 137; INSEE, 2014). Recent emigration for education stems from the lack of higher education offered in the Territory and the increased bursaries supporting these endeavours ${ }^{2}$ (IEOM, 2015; Vakala, 2008). As a result, although studies have shown that the level of education in the territory has increased, there has been a substantial lack of return from young graduates (INSEE, 2009). Migration for education in Wallis and Futuna is therefore a relatively recent occurrence at this scale and has yet to be approached in academic literature.

For this research project, a constructivist grounded theory study is adopted based on Talanoa interviews conducted in Wallis, Futuna and New Caledonia. The research examines the impact of migration for education on the islands of Wallis and Futuna and assesses the possibilities of return of skilled migrants to contribute to local development. The research is situated within the framework of development, migration and education and informed by the migration, remittances, aid and bureaucracy (MIRAB) model.

\subsection{Research framework}

\footnotetext{
${ }^{1}$ «Une forte préoccupation ressort au déclin de la population, qui semble s'accélérer et touche en particulier les populations jeunes. A fin 2014, la population est estimée à moins de onze mille habitants » (IEOM, 2015, p. 9).

${ }^{2}$ Since the early 20oos, students are entitled to two different grants either from the territory (bourse territoriale) (Prefecture des Isle Wallis et Futuna, 2016) or from the state (bourse CROUS) (CROUS Paris, 2016). The grants are available to students depending on social criteria; such as parents' income and other factors determined by a points system. Additionally, students from overseas department are automatically provided the 'passeport mobilité, a service provided that covers travel costs (air fares) (IEOM, 2015; LADOM, 2016).
} 
This study is placed within a framework of development, migration and education to identify the role and relationship between each component and how it affects Wallis and Futuna. The literature available presents that the impact on each other is open to debate and context dependent.

Recently, migration has been growing into a "central dynamic within globalisation" as movement has become easier with technological, cultural and political changes (Castles \& Miller, 2009, p. 2). According to Castles and Miller (2009), migration will continue to grow as people continue to flee conflicts and difficulties in their home countries, search to build a better life and search for better economic opportunities. More recently, there have been key debates pertaining to the relationship between migration and development. Whether migration can benefit development or whether it is leading countries into perpetuated underdevelopment is a constant debate (Gamlen, 2010, 2014; Portes, 2008).

Skeldon (2008) believes that "migration from the developing to the developed world [plays] an important role in the development of the poorer countries of origin" (p2) and ought to be considered as a positive for development, rather than a negative. Castles and Miller (2009, p. 58) similarly outline noticeable benefits to sending countries incurred by monetary remittances, social remittances (in the form of skills and attitudes), brain circulation (over brain drain), temporary labour migration and diasporas.

The argument that migration could benefit all parties involved is still weak. Studies suggest that migration will affect different countries in different ways and for various reasons but sending countries may not always benefit from this movement (Skeldon, 2008). Additionally, scholars stress that a positive relationship between migration and development is simply "not automatic" (Portes, 2008, p. 37) as countries are subjected to important economic, political and social structures (Smith \& Favell, 2006).

This debate expands to the concept of human capital formation and the loss of skilled labour incurred by outmigration. Human capital has long been seen as a 
vital resource for economic growth (Williams \& Baláz, 2008) but the benefits from human capital are less visible in a situation where the skilled populations leave for opportunities elsewhere (brain drain) (Adams \& Douglas, 1968). In a similar trend to the migration and development debate, recent literature has looked into how emigration of skilled population may lead to greater human capital formation in the home country and ultimately lead to greater development (brain gain)(Fan \& Stark, 2003). Yet, evidence to support this theory also requires further investigation. Literature thus shows that the brain gain and brain drain theories are subjected to different conclusions contingent on various factors in the host countries, sending countries and migrant agency.

In particular, studies in the Pacific and smaller states indicate that smaller populations could be vulnerable to the negative effects of skilled emigration (Beine, Docquier, \& Rapoport, 2008; Beine, Docquier, \& Schiff, 2008). Here, outmigration has been seen as particularly affecting the smaller islands, as the push away is greater than the pull back home (Gibson \& McKenzie, 2012).

This is particularly significant for economies who benefit from free association with metropolitan countries and MIRAB economies where migration is a central variable that has helped uphold living standards and provided a labour safety net for Pacific workers (Watters, 1987, p. 33).

\subsection{The MIRAB model}

The benefit of close association between small Pacific Island countries and a metropolitan power is a particularly predominant topic in the Pacific region since many islands are in association with developed nations as a result of colonial history or geographical proximity (Firth, 2006). Studies have shown that overseas territories and states that are attached by free associations to a rich metropolis would have much higher standards of living particularly when they are subsidised by developed countries (Baldacchino, 2006; Firth, 2006; Overton, 1993; Thodock, 2007). Baldacchino (2006, p. 45) compared these associations to an outside "hinterland" for resource-lacking Pacific Islands. Metropolitan centres 
provide "extra-territorial resources" such as goods and services to insular Pacific territories and states. In the region, these associations have been crucial and the MIRAB model has sought to explain how islands have benefited from the hinterland but have also been impacted.

The MIRAB model was coined by Bertram and Watters (1985, p. 497) to explain the experience of insular microstate economies and determine the sustainability of a system that is based on migration, remittances aid and bureaucracy (MIRAB).

MIRAB applies to islands that demonstrate a "common heritage of colonial welfarism" (Bertram, 2006, p. 1) where islands remain dependent on the metropolitan centres and have relatively high living standards despite having limited economic activity. Dependency here helps compensate for economic deficit through rent incomes such as "aid, remittances and other invisibles such as tourism or philatelic sales" (Watters, 1987, p. 33).

Migrants "exploit economic opportunities" (Bertram \& Watters, 1985) due to open border agreements and Watters (1987) estimated in 1987 over half of the populations of insular economies resided in metropolitan centres. As a result, overseas migrants have developed a "transnational corporation of kin" used by the local populations as a "rational household strategy" (Watters, 1987, p. 37) where communities and families remaining in the islands can profit from not only remittances, but can also create 'niches' overseas for the placement of future migrants (Bertram \& Watters, 1985; Watters, 1987). Those who remain on the islands in turn help maintain the culture, heritage, land and other assets (Watters, 1987, p. 37).

In addition, living standards are supported by aid assistance which acts as budget supplement for the government (Bertram \& Watters, 1985, p. 499; Watters, 1987). Bertram and Watters (1985, p. 499) note that "aid is clearly crucial rather than peripheral in the determination of incomes and consumption levels" since in MIRAB societies, over 50 per cent of employment is in the public sector and overseas aid funds a large part of imports. 
Since MIRAB economies are dependent on external rentier investments, Bertram and Watters (1985, p. 499) stress that the ability to use funding for investment or to support economic activity quite simply "does not exist". Island territories and states have been able to strategically weigh-up limitations from production and economic activity on the islands against benefits provided by local government employment or income opportunities overseas (Bertram \& Watters, 1985, p. 511).

In fact, in the MIRAB structure, aid and remittances injections and the prevalence of bureaucratic employment act as an additional disincentive or 'crowding-out' of economic activity as "there is no automatic link between increased local production and increased economic welfare" (Bertram \& Watters, 1985, p. 512). Bertram (2006) and Watters (1987) further argue that in a MIRAB economy 'productive' activities to promote development are generally underused or require additional subsidies. For instance, activity within the private sector is dependent on government financial support and consumer spending from waged public servants, as was evident in the case of Niue (Connell, 2008, p. 1037). Poirine (1994, p. 1997) also believes that investment in domestic activity is limited due to the higher costs of wages on the islands that “are driven up by better paid overseas employment".

Moreover, economic activity as employment is not economically viable to the individual in such societies. Watters (1987, p.47) claims that those who can't find employment in the bureaucratic sector have better prospects abroad. Watters (1987, p. 48) adds that this might also turn bureaucracy into a 'social security system' where bureaucracy will expand in order to provide jobs to a larger portion of the population- a system that would only reinforce the dependence on foreign aid. Furthermore, Watters (1987) notices that the higher wages in bureaucracy have created a "bureaucratic class" that has gained political responsibility “with its own particular interest and values” (Watters, 1987, p. 50).

At the time, Bertram and Watters (1985) thought that the MIRAB structure was likely to persist in Small Island economies if the four main variables remained 
stable. However, the sustainability of this model has more recently been questioned. It has been argued that MIRAB societies are in fact not static due to the variables involved.

\footnotetext{
"The sustainability or otherwise of MIRAB economies remains an open research issue, because in the long run remittances may suffer decay and aid donors may suffer fatigue" (Bertram, 2006, p. 3).
}

Newer models have since arisen to explain ways in which island economies have been able to leave the mould (Baldacchino, 2006, p. 55). Baldacchino (2006, p. 49) theorises that island development could have "non-MIRAB, pre-MIRAB and/or post-MIRAB strategies for engaging with the hinterland beyond". Models such as the PROFIT (People considerations; Resource management; Overseas engagement; Finance, Insurance and taxation; Transportation) societies or SITEs (Small Island Tourist Economies) (Bertram, 2006) have proven that economies have been able to produce activity in spite of their dependence to metropolitan cores.

Bertram compared these economies to a kaleidoscope where change is inflicted to "the external situation by rotating the instrument, and shift takes place, quickly settling into a new stable pattern which persists for as long as the tube is held still" (Bertram, 2006, p.12). In this case, one variable changes, the entire way the society works shifts and it cannot be reversed (Bertram, 2006, p.12). Bertram (2006, p.12) predicted that there may be a "new stable temporary equilibrium" containing the same elements caused by "external circumstances" but could not envisage the new future pattern.

Despite the variation of the models to describe such economies, it is clear that association with metropolitan cores is key for economic survival, to maintain living standards, "consumption levels" (Bertram, 1986, p. 820) and to perpetuate labour movement to the centres (Baldacchino, 2006; Bertram, 1986, 1993; 
Bertram, 2006; Bertram \& Watters, 1985; Overton, 1993, p. 269; Poirine, 1993, 1994, 1998; Watters, 1987).

As a result, the MIRAB evidently challenges the modern understanding of sustainable development, which in this case is not applicable to Small Pacific Islands (Bertram, 1986, 1993). Similarly, Poirine (1993, p. 1197) concludes such economies may be identified as unstable but through a strategic use of rent, aid incomes and transnational networks have established an alternative stability. Baldacchino (2006, pp. 46-47) concurs that sustainable development is perhaps not the objective "because the small local-insular would not survive without drawing in resource and assets from, while flushing out excesses and undesirables to, a hinterland beyond".

The description of Wallis and Futuna demonstrates very similar characteristics of an economy based on migration, remittances, aid and bureaucracy (MIRAB) (van der Grijp, 2002). The research will be using the model as a foundation to the study or as an additional framework. 


\subsection{Wallis and Futuna}

\subsubsection{Geographical overview}

Wallis and Futuna is a dependent French overseas collectivity, known as a COM (Collectivité d'outre mer), formally known as TOM (Territoires d'Outre-Mer) and part of the French overseas departments and collectivities abreviated to 'DOM-COM' (Departements d'Outre-Mer- Collectivités d'Outre-Mer) or 'DOMTOM' (Departements d'Outre-Mer - Territoires d'Outre-Mer). Through the association with France, Wallis and Futuna is part of Europe and falls under the European accronym of PTOM (Pays et Territoire d'Outre-Mer) or OCT (Overseas Countries and Territories) (IEOM, 2015).

The territory of Wallis and Futuna is a collection of three Polynesian islands; Wallis (Uvea), Futuna and Alofi, located between Fiji and Samoa in the heart of the South Pacific, as shown in Figure 1. The islands of Futuna and Wallis are separated by $230 \mathrm{~km}$ of ocean (Angleviel, 2004, p. 84) and are situated approximately $2000 \mathrm{~km}$ from the nearest francophone neighbour, New Caledonia. In 2014, Wallis and Futuna had an estimated population of 10,934 with a large majority of the population living in Wallis (IEOM, 2015). Alofi Island is uninhabited and is predominantly used as farmland.

The islands are a "culturally unique" French-speaking Catholic Polynesian territory on the border with Melanesia and surrounded by predominantly English-speaking Protestant islands (Angleviel, Agostini, Dupuy, \& Lavault, 1998, p. 232).

Wallis and Futuna fall under the same French system but have distinct customary hierarchies and tradition stemming from different ancestral linkages from Tonga (Wallis) and Samoa (Futuna) (Angleviel \& Papilio-Halagahu, 2014; IEOM, 2015). There are three kingdoms in the territory: one in Wallis and two in Futuna. 
The local languages are Wallisian, Futunan and French. Wallisian and Futunan are the vernacular languages used in local homes and French is used in employment and schools.

\subsubsection{Since the statute}

The islands were never colonised by France but were heavily influenced by the arrival of French Catholic missionaries from the société de Marie in 1837, which began a thorough process of evangelisation. Wallis and Futuna became a French protectorate in 1888 until 1961 when it became a territory of France (Angleviel \& Papilio-Halagahu, 2014). In 2003, Wallis and Futuna became a collectivite d'outremer (overseas collectivity) which did not incur any changes to the statute (IEOM, 2015, p. 19).

The statut de 1961, hereinafter referred to as the statute, is an agreement or constitution to delimit Wallis and Futuna's political, social and economic ties to France and was signed in 1961.

Prior to its signature, the kings in Wallis and Futuna requested that (i) the statute allowed Wallis and Futuna to preserve their customs and institutions alongside the republican institutions, (ii) the republican laws be transferred only when approved by the local authorities, (iii) the territory benefit from autonomous management and administration that is independent from New Caledonia, and (iv) that a government committee reuniting the three kindgoms be created (Angleviel \& Papilio-Halagahu, 2014, p. 73). After much negotiation and a local referendum, the statute was signed in 1961. The document has had very few revisions since and there have been no requests for independence (Angleviel \& Papilio-Halagahu, 2014; Migaud, 2014).

Since then, the French administration and justice system known as the 'droit commun' and the customary Wallisian and Futunan justice system known as the droit coutumier (van der Grijp, 2005) have compromised to coexist. The statute 
emphasises that Wallisians and Futunans are French nationals, hold the same rights and freedoms as any French citizen and are subjected to the same obligations. Simultaneously, the statute permits customary power over land rights and customary matters which do not fall under the French justice system. As highlighted in the statute,
"The Republic guarantees to the population of the territory of Wallis and Futuna Islands the right to practice their religion freely and will respect their beliefs and traditions as long as they are not contrary to the general principles of people's rights or of the current law"3 ("Loi n ${ }^{\circ} 61-814$ du 29 juillet 1961 conférant aux îles Wallis et Futuna le statut de territoire d'outre-mer (1) ", 2012, p. 1).

Since 1961, the French state has brought modernity through increased funding and services such as free access to education, health care, roads, electricity, telephone connections, television, radio, ports and airports, among many other services and infrastructures (Angleviel, 2004; Angleviel \& Papilio-Halagahu, 2014; Tafalagi, 2004).

Young Wallisians and Futunans now follow the French education system. The secondary school curriculum is managed by the state and the primary school curriculum is determined by the Catholic Church (IEOM, 2015; Likuvalu, 2004). Although the French system is secular by law, Catholicism maintains a significant presence throughout the students' education. There are nine kindergarten and primary schools in Wallis and six in Futuna, four colleges/ middle schools in Wallis and two in Futuna, and two high schools in Wallis (one

\footnotetext{
3 « La Republique guarantit aux populations du territoire des iles Wallis et Futuna la libre exercice de leur religion, ainsi que le respect de leurs coryances et de leurs coutumes en tant qu'elles ne sont pas contraires aux principes generaux du droit et aux dispositions de la presente loi » ("Loi n 61-814 du 29 juillet 1961 conférant aux îles Wallis et Futuna le statut de territoire d'outre-mer (1) ", 2012, p. 1)
} 
general and one agricultural high school) (IEOM, 2015, p. 79).

\subsubsection{Political structure}

The statute provides specific authority and responsibility to three main bodies: the Administration Supérieure (Civil Service), the Assemblée Territoriale (Territorial Assembly) and the Autorité Coutumière (Customary Authority) (IEOM, 2015). Wallis and Futuna are divided into six districts and each is represented by their circonscription (district representative) (IEOM, 2015). The districts in Wallis are Hihifo, Hahake, Mua and are Sigave and Alo on Futuna, as demonstrated in figure 3 below.

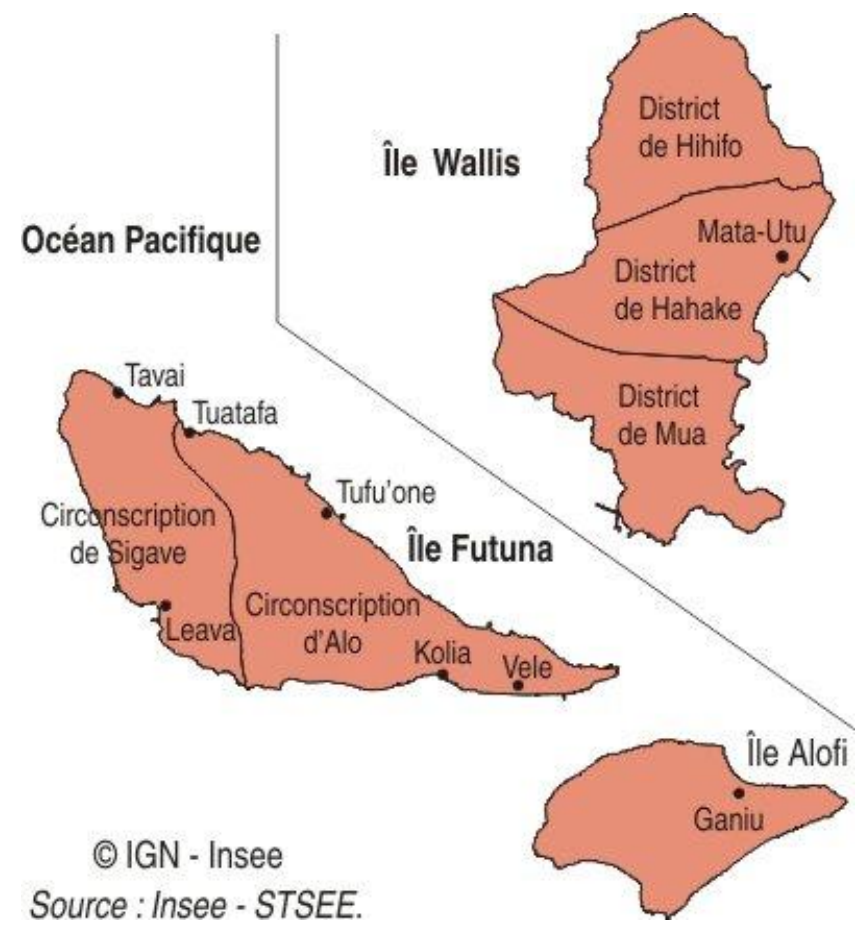

Figure 3 Wallis and Futuna districts. Source: INSEE (2009)

The responsibilities have been outlined in Figure 4 and in the text below.

\begin{tabular}{|l|c|c|}
\hline \multicolumn{1}{|c|}{ State } & Customary Authority & Territorial Assembly \\
\hline$\bullet$ Security & $\bullet$ Customary land & $\bullet$ Deliberative \\
$\bullet \quad$ Respect of the law & tenure & assembly \\
- Treasury & & (consultations) \\
\hline
\end{tabular}




\begin{tabular}{|c|c|c|}
\hline $\begin{array}{ll}\text { - } & \text { Customs } \\
\text { - } & \text { Foreign Affairs } \\
\text { - } & \text { Monitoring of } \\
\text { adminisration } \\
\text { - } \text { Monitoring of } \\
\text { - } \text { Hinances } \\
\text { - } \text { Middle school, } \\
\text { High school and } \\
\text { higher education }\end{array}$ & 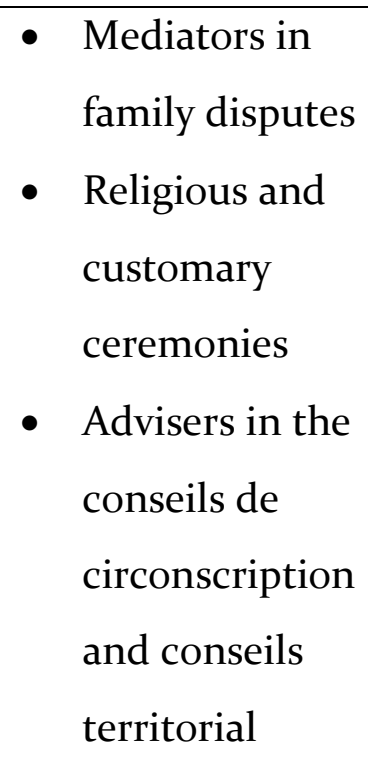 & $\begin{array}{l}\text { Advisers for } \\
\text { decisions in the } \\
\text { Civil Service }\end{array}$ \\
\hline
\end{tabular}

Figure 4 Division of responsibilities of the State, Customary Authority and the Territorial Assembly. Adapted from IEOM (2015)

The Administration Supérieure (administration) serves as the civil service from the state. The Préfet (prefect) or Administrateur Supérieure (administrator) acts as the representative of the State in the territory and the chef du territoire (territorial chief). He/she has executive power over decisions concerning the criteria outlined above (figure 4 ). The Administrator has a deputy representative on Futuna (IEOM, 2015).

The Autorité Coutumière (Customary Authority) through the statute has retained authority over customary and religious matters such as land ownership and ceremonies. Customary chiefs are highly regarded in Wallisian and Futunan society to uphold tradition and have an important place in the political sphere, particularly in the Conseil Territorial (Territorial Committee) (IEOM, 2015). The delimitations of the kingdoms on Futuna are the same as the circonscriptions, as shown in Figure 3. Each kingdom has its own organisation and hierarchy and works independently of each other. The kingdom of Uvea has one king, one prime minister and five ministers. There are three customary chiefs, one for each district and 20 village chiefs, one for each village. In Alo and Sigave, the king is accompanied and advised by the grande chefferie (chiefdom) comprised of a minister from each village (Malau, Takasi, \& Angleviel, 1999). 
The Territorial Committee is composed of the Prefect, three customary chiefs from Wallis and Futuna, typically the three kings, and three representatives chosen by the Prefect and approved by the territorial assembly. Le Territorial Committee has an important role in assisting the Prefect with decisions pertaining to the civil service in the territory. The committee processes and approves or rejects projects prior to being forwarded to the Territorial Assembly for consideration (IEOM, 2015).

The Territorial Assembly is composed of twenty political representatives, known as the elu (elected ones) who are elected by the local populations. There are six representatives from Mua, four from Hahake, three from Hihifo, four from Alo and three from Sigave. The élu are supported by a Commission Permanente (Permanent Commission) composed of four members who also serve as representatives of the three districts in Wallis and Futuna: Uvea, Alo and Sigave. The Territorial Assembly plays a crucial role of representation of Wallis and Futuna but has limited authority in decision-making (IEOM, 2015).

Wallis and Futuna have been able to negotiate a certain amount of autonomy in politics through the retention of chieftaincy, custom and the creation of local political parliament. The traditional land tenure system still prevails as land is controlled by kinships and by the chiefdoms and there is no land registry (van der Grijp, 2002, 2005). However, the state still retains authority and "tries to maintain control over the indigenous political system through annual grants" to the chiefdoms in Wallis and Futuna and provides monthly allowances to chiefs (van der Grijp, 2002, p. 18; 2005, p. 312).

Many deem the statute as outdated as it has not undergone many changes since it first came into being. There have been many attempts for the statute to be updated in particular to provide the Territorial Assembly with more executive power. These changes were not put through due to disagreement with the terms from the other main authorities, in particular with the customary authorities (IEOM, 2015, p. 19). 


\subsubsection{The economy and culture}

According to van der Grijp (2002, 2003, 2005), Wallis and Futuna has an identity similar to surrounding Polynesian societies. Wallis and Futuna can be characterised by these four main features: (i) an important presence of chiefdoms, (ii) cognatic kinship taking precedence over "social relations of production (and) distribution policies", (iii) presence of land tenure controlled by kinship relations and chiefdoms, and (iv) subsistence-based, gift-based and barter-based economies (van der Grijp, 2002, 2005).

Employment in the private sector started to grow in the 1980 os in Wallis in particular as more qualified school-leavers were being employed in the public sector (Tafalagi, 2004). In 2013, there were 4482 people of a working age (IEOM, 2015, p. 30). In 2014, the public sector counts for 60.2\% (1250 people) of declared employment and the private counts for 828 declared waged workers (IEOM, 2015, p. 28).

The association with France has driven up wages in the territory. The minimum wage in Wallis and Futuna has increased to 90 ooo CFP in the private sector and to 89149 CFP in the public sector (IEOM, 2015, p.33). The minimum wage is significantly higher than the rest of the Pacific region and lower than in France and New Caledonia. The increase in wages on the islands has led to a growing middle class in the territory (van der Grijp, 2002, p. 20). In addition to waged employment, remittances from migrants "play a vital part in the economy" (Maclellan \& Mares, 2006, p. 138). Given the marginally fewer employment opportunities on Futuna, money is scarcer yet the island is evidently going through a similar process of monetisation as Wallis a result of remittances and state financial transfers (van der Grijp, 2005, p. 328). The processes of modernisation are evident as more cars and concrete houses make up the landscape of the territory, particularly in Wallis where the traditional fale as traditional housing is becoming rare. 
Additionally, Wallis and Futuna has been exempt from taxes to encourage productive investment to the territory and, as a result, wages do not incur taxes (Cour des comptes, 2010). The territorial budget is then heavily reliant on taxed imported goods, which contribute $70 \%$ of tax revenues (IEOM, 2015, p. 44). The remainder of the territorial budget is comprised of state budget transfers that pay for the salaries of metropolitan employees in the public sector and subsidise the upkeep of the premises (Angleviel \& Papilio-Halagahu, 2014, p. 95). Inhabitants on the islands are not subjected to other taxes and many services such as medical and education are free. The territory is also dependent on outside aid assistance by the European Union and quinquennial contracts 'Plan Etat-Territoire' that contribute to infrastructural development (Angleviel \& Papilio-Halagahu, 2014, p. 95).

Although culture has maintained precedence within the society, the system has also been adapted to fit alongside capitalist economic systems and survives beside a "western system of power" (van der Grijp, 2005, p. 314). Subsistence farming, the ability to cultivate, gifting and bartering, continue to be significant representations of wealth (van der Grijp, 2002). Increased access to money has led to increased consumerism, which has filtered into the traditional aga'i fenua (custom), barter, subsistence and gift system (Tafalagi, 2004; van der Grijp, 2002, p. $20 ; 2005$, p. 312 ) and as a result have forged growing inequalities in the ability to practice custom or fatogia (obligations towards the chiefs) along with inequalities in standards of living (Tafalagi, 2004).

The ability to practice aga'i fenua or fatogia is also linked to a person's respect in society and the 'right to speak out' (van der Grijp, 2002, p. 28). According to van der Grijp (2002, 2003, 2005) and Malau (2004) there continues to be pressure on the populations to participate in customary and religious traditions by giving the largest pig for instance in order to maintain respect from the chiefs and the village.

Land is based on customary land tenure where kinship groups own the land. Similar to many Pacific cultures, land “is an extension of one's membership of 
this clan" and is "the only kind of property that can be called permanent" (Malau, 2004, p. 168). Land is passed down through generations and is allocated by the family representatives and senior family members (Malau, 2004). As there is no register to document land ownership, disputes regarding land ownership are settled by village chiefs or kings. Public land is managed by the king, high chiefs and village chiefs (Malau, 2004). This system also means that land cannot be sold but it can be lent.

\subsubsection{Development}

According to the statute, the state is committed to assisting development in the territory.
"(The state) takes all the required measures to ensure the economic development of the territory, particularly through the financial investment funds and the funds of social and economic development" 4 ("Loi n 61-814 du 29 juillet 1961 conférant aux îles Wallis et Futuna le statut de territoire d'outre-mer (1) ", 2012, p. 1).

According to Angleviel and Papilio-Halagahu (2014, p.96), modernity 'as perceived in the 196os' is present through the provision of modern services. Wallis and Futuna is also characterised by a high standard of living compared to the rest of the South Pacific (Angleviel \& Papilio-Halagahu, 2014; van der Grijp, 2002), "at least for those Wallisians (and Futunans) who have access (directly or via kin networks) to government salaries” (van der Grijp, 2002, p. 28).

As a result of the territory's affiliation with a European member state, Wallis and Futuna falls under the Overseas Countries and Territories (OCT) of the European

\footnotetext{
4 « Elle (l'Etat) prend toutes mesures propres à assurer le développement économique du territoire, notamment par l'intermédiaire du fond d'investissement et de développement économique et social » ("Loi n 61-814 du 29 juillet 1961 conférant aux îles Wallis et Futuna le statut de territoire d'outre-mer (1) ", 2012, p. 1)
} 
Union as part of the European Development Fund as of November 1999 (Angleviel and Papilio-Halagahu, 2014, p. 95). The European Union and the Secretariat of the Pacific Community fund environmental projects locally.

Despite high standards of living and access to services such as health and education, the potential for economic development is a constant concern for Wallis and Futuna. Angleviel and Papilio-Halagahu (2014, p. 95) stated that Wallis and Futuna is being sustained 'on a drip'. There is high financial support but the solutions for the lack of economic development and high dependence on the state are still a concern (Angleviel, 2004; Migaud, 2014).

There have been few evident successful development projects in the islands (Migaud, 2014; van der Grijp, 2005, p. 328). The lack of economic development has long been attributed to barriers stemming from the outdated statute (Migaud, 2014), the territory's 'total dependence' on imports (Roux, 1995), unsellable land (van der Grijp, 2005, 2002) or "indigenous representations of work and ... cultural constraints on leadership” (Van Der Grijp, 2002, p.17).

It appears that in part, the merging of two systems (French and Wallisian/Futuna) and modernity have been met with concerns from the local population particularly in terms of loss of local representation and the practice of aga’i fenua (custom)(Tafalagi, 2004).

In 2005, Wallis experienced a crise royale and coutumiere (customary crisis) due to a disagreement between the royal family and the French law. The grandson of the king at the time was sentenced to 18 months for involuntary homicide, which customary authorities deemed unjust. As the grandson of the king, the offender was 'above republican laws' (Angleviel \& Papilio-Halagahu, 2014, pp. 89-9o). The territory was subsequently divided between supporters of the monarchy (royalists) and supporters of customary reform (reformists). This led to violence and unrest on the island and was only resolved when the offender gave himself in to the authorities (Angleviel \& Papilio-Halagahu, 2014, pp. 89-90).

Additionally, according to Likuvalu (2004, p.132), education has contributed to a 
new generation in the territory; "better educated, prepared for administrative, political and economic functions, but rejecting tradition, the requirements of custom and of culture" (p.132). Additionally, younger generations have started to question the established customary and religious authorities due to growing exposure, connections to and visits abroad and are no longer drawn to working on the land because they were drawn to western modern lifestyles (Henningham, 1992 cited in van der Grijp, 2002, p.29).

These changes have been largely enforced by the recent surge of migration and increased exposure to globalisation.

\subsubsection{Migration from Wallis and Futuna}

As a French overseas collectivity, Wallisians and Futunans can migrate freely to and work within France and other DOM COM (Angleviel, 2004; Poirine, 1994). Migration from Wallis and Futuna is not a new phenomenon for the territory or the region and received much attention in some reports and a selection of studies (Angleviel, 2004; Angleviel et al., 1998; Angleviel \& Papilio-Halagahu, 2014; Connell, 1983; de Deckker, 1998; Finau et al., 2009; Rallu, 1982, 1994; Roux, 1995). There have additionally been studies conducted by statistics bureaus such as INSEE (2009, 2014) and IEOM (2015), some local territory reports and literature, such as (Angleviel \& Papilio-Halagahu, 2014), which have mentioned the topic of emigration from Wallis and Futuna. Anglophone and Francophone academic studies, on the other hand, are scarce and Wallis and Futuna rarely appear in Anglophone literature in particular. There have been studies approaching the topic of migration in Wallis and Futuna such as Roux (1985) which focused on the diaspora in New Caledonia and other studies in Wallis and Futuna that have been part of a wider research project such as that by Baudchon (1992). The most significant studies that will inform this study are Connell (1983) and Angleviel (2004). Wallis and Futuna does appear in Pacific-focused research projects but very rarely, especially in Anglophone literature.

The available studies have shown that migration to and fro has fluctuated over 
time for Wallis and Futuna and appears to follow the changing incentives to migrate. New Caledonia has historically been the primary destination of Wallisians and Futunans wanting to leave the territory due to its proximity and networks that have been built over time. Wallisians and Futunans have been moving to New Caledonia since the 1940 (Baudchon, 1992, p. 344) and according to Baudchon (1992, p. 335), migration from overseas departments was a solution to overcrowding on the islands in the 1950s. In the 1970s, migration to New Caledonia increased in response to the growing need of workers to support the nickel boom. Once this nickel boom collapsed at the start of the 1970s, Wallis and Futuna experienced a high return of migrants to the territory (Baudchon, 1992; Connell, 1983). At the time, Baudchon (1992, p. 347) argued that the return of the migrating population to Wallis and Futuna "would have disastrous effects on the economic and social life of Wallis and Futuna and therefore on its political life" because it did not have the structures or resources to support such a large population. In the last few decades, the reason for emigration has predominantly been for employment in New Caledonia, particularly for low qualified employment (Angleviel, 2004).

The most applicable study for this research is the Migration, Employment and Development in the South Pacific Country Report Number 21 Wallis and Futuna by Connell (1983). At the time "there had never been a detailed study of emigration from Wallis and Futuna" (Connell, 1983, p.15) and today this is still the case. Connell (1983) tried to identify the principal rationales for migration and hypothesised that emigration fluctuated with these criteria: higher wages in New Caledonia, increased socioeconomic inequalities between Wallis and Futuna and New Caledonia, land pressures, limited employment opportunities in the territory, 'increased wants', modernity abroad and cultural conservatism at home, military service, established networks, welfare services, healthcare, economic opportunities and ease of travel (p. 16-19). In addition, Connell (1983) identified that emigration was commonly with the intent of permanent settlement (p19). Connell speculated that the lack of return was possibly due to the stigma that returning was a 'failure' (p19). However, at the time, due to the 
lack of detailed studies on emigration from Wallis and Futuna, the impact of migration in the territory was unknown. The study did nevertheless highlight evident social changes incurred by return migration and attributed to modernity such as a decline in religious and customary respect and authority, increased crime and decreased nutritional and health standards (Connell, 1983, p. 23). The study concluded that Wallis and Futuna had limited possibilities for economic development and it would be difficult for the territory to escape dependency on the state and on remittances from overseas migrants. According to Connell (1983), the viability of Wallis and Futuna's socio-economy at the time was "being slowly eroded" (p.27).

Angleviel (2004) considered the role of migration and the options for development in Wallis and Futuna. The article highlighted that Wallis and Futuna would have to survive on a "voluntarist policy of emigration" alongside the "implementation of a certain degree of self-development taking into account the strong constraints of an island micro-society" (Angleviel, 2004, p.91). The possibilities for migration would enable populations to find employment overseas given the limited opportunities in Wallis and Futuna, whilst selfdevelopment could enable potential returnees to be 'passive consumers' (p. 88) and support the growth of micro-businesses in the territory. For Angleviel (2004, p.88), migration "has always been a necessary phenomenon in limited island surroundings" and development would require a continued flow of migration. Yet, the sustainability of these islands depends on a development that can enable local residents to benefit from elements of modern society (Angleviel, 2004).

Angleviel (2004) also identified the pressures incurred in the labour market in New Caledonia as a result of emigration from Wallis and Futuna. This led to a request by local authorities for destination diversification strategies to create 'new migrant flows' to places like metropolitan France (p. 86). These concerns of population pressures in New Caledonia and lack of structures for development in Wallis and Futuna resulted in a development strategy for Wallis and Futuna in 2002 and an 'accord particulier' (special agreement) in 2003 (Angleviel, 2004). The special agreement committed all parties involved (the State, New Caledonia 
and Wallis and Futuna) to "use the resources necessary, for harmonised economic development that allows training and certification, access to employment, social security and health protection in order to maintain the populations of Wallis and Futuna in the territory"5 ("Accord Particulier entre l'Etat, la Nouvelle-Caledonie et le Territoire des Iles Wallis et Futuna ", 2003, p. 3).

\subsection{Thesis Rationale and questions}

So far, there have been no academic studies on the impact of education on migration flows and on its role in the development of Wallis and Futuna. Although recent reports have identified that the number of young migrants leaving for higher education has been increasing and the percentage of skilled populations for the young generations has been steadily growing as a result (INSEE, 2014), there appears to be no academic studies addressing this phenomenon in the territory. In addition, the impact of education on a MIRAB society has yet to be discussed in any depth.

To address this apparent gap, the study will be situated within the framework of development, education and migration focusing primarily on whether Wallis and Futuna has been benefiting from access to education in their hinterlands ${ }^{6}$. The MIRAB model will be used as a foundation to explain the economic structures and address the question of sustainability and stability of Wallis and Futuna as a MIRAB society. The study may also be used to shed some light on

\footnotetext{
5 « Le Territoire des Iles Wallis et Futuna s'engage à créer les conditions favorables, et à trouver avec l'aide de l'Etat et de la Nouvelle-Calédonie selon des modalités à arrêter les moyens nécessaires, à un développement économique harmonieux permettant une formation diplômante, un accès à l'emploi, une couverture sociale et un protection en matière de santé de nature à maintenir les populations de Wallis et Futuna sur le territoire » ("Accord Particulier entre l'Etat, la Nouvelle-Caledonie et le Territoire des Iles Wallis et Futuna ", 2003, p. 3)

${ }^{6}$ The word hinterland will be used in this research, in the same ways as Baldaccino (2006), to describe overseas countries and territories accessed by migrants from Wallis and Futuna. The hinterlands of Wallis and Futuna in this research are predominantly France, New Caledonia, French Polynesia but could also encompass other DOM COM and countries such as New Zealand and Australia.
} 
the phenomenon in the territory to assist Wallis and Futuna in its quest to respond to the rapidly decreasing population.

The thesis research will seek to respond to the following overarching question:

\section{What role does migration for education have within the MIRAB economy of Wallis and Futuna?}

\subsection{Thesis outline}

This thesis has six chapters and is structured to present the links between the brain drain and brain gain literature, the MIRAB model and the context of Wallis and Futuna.

Chapter Two investigates the available literature on migration, education and development, outlining in particular the impact of skill drain on sending countries and the possibilities of a return of these skills.

Chapter Three explains the methods used throughout the research, including in particular fieldwork and the analysis processes. The methodology includes a reflexive piece on my positionality and its impact during the research process.

Chapter Four presents a collection of key findings collected in Wallis, Futuna and New Caledonia through interviews.

Chapter Five discusses these findings and provides links to the literature and notes crucial findings that challenge established theoretical understandings.

Chapter Six provides the key conclusions extracted from the research and provides significant new dimensions to established theories. 


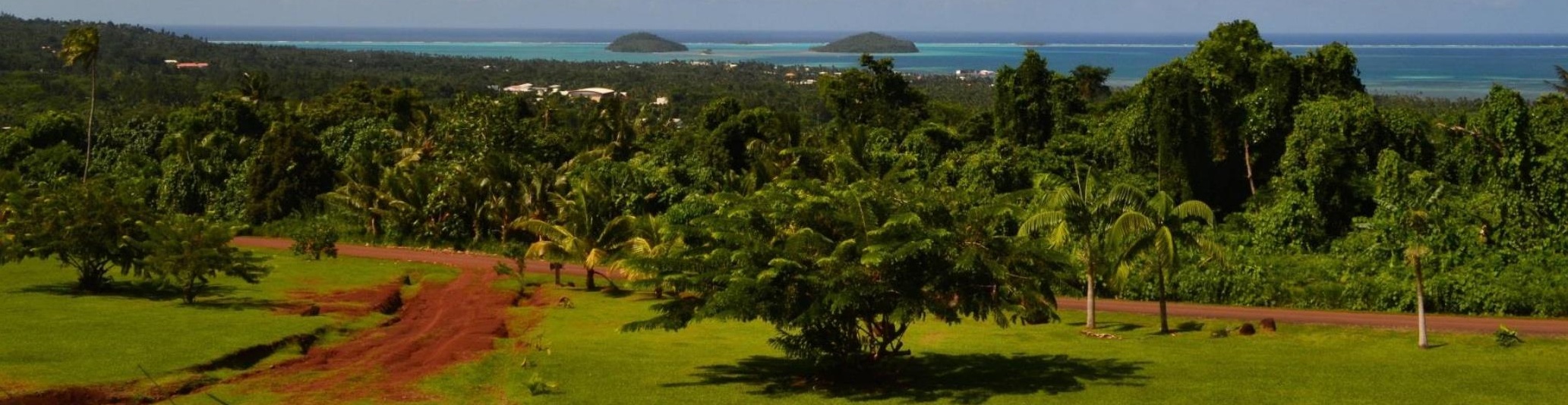

\section{View of Wallis}

Photo by author

Chapter Two: Migration, Education and Development in the literature 
The literature review focuses on migration, development and education. It presents a mirrored comparison between the global context and the context in the Pacific. Firstly, the impact on migration and development will be assessed and the question is raised whether migration can provide positive returns and promote development in sending countries. Secondly, education and migration are considered as skill migration and studies will be assessed outlining the impacts of skill emigration on the development of sending countries. Thirdly, literature on the policies for migration and the possibilities of promoting return or limiting migration will be reviewed.

It is important to acknowledge at the outset that to categorise migration from Wallis and Futuna as international migration or internal migration is problematic. Given the territory's particular status of association, the literature review investigates studies concerning international migration in the global context but also identifies studies pertaining to internal migration in the context of dependent and independent Pacific Islands.

The literature is guided to respond to these three questions.

* How does migration impact development?

* What is the role of migration for education (brain drain and brain gain) in developing states and territories?

* What are the possible solutions to address outmigration and the brain drain?

\subsection{The global context of migration}

\subsubsection{Migration and development}

Many theories have emerged in an effort to explain the relationship between migration and development but these are constantly contested and redefined as development and migration thinking swings back and forth like a never-ending 
pendulum (Gamlen, 2010, 2014). Although migration has often appeared to have negative impacts on the development of the sending countries, in the last 20 years migration has been suggested as a phenomenon that could be used as a tool for development (Skeldon, 2008).

It is apparent in the literature that the focus to determine the relationship between development and migration is a relatively recent interest. Migration studies scholars have argued that there is no coherent theory to explain population movement (Bodvarsson \& Van den Berg, 2009; Massey et al., 1993). Rather, there is a disjointed collection of non-'cumulative' concepts (Munck, 2009, p. 4). The concept of migration is so vast and "multifaceted" and the study of it needs to encompass "a variety of perspectives, levels and assumptions" (Massey et al., 1993, p. 432). Traditional theories relating to economic push and pull factors (explained in depth in Bodvarsson and Van den Berg (2009)) have been criticised as being one-sided (Munck, 2009, p. 4) and provide a limited representation of the impacts and motives of migration on the three parties involved: the host country, the home country and the migrant. Appleyard (1989) believes that the experience of the sending countries will depend on the variables taken into consideration, on the countries' stage of development and on the type of migration that it is experiencing. Similarly, Castles and Miller (2009, p. 26) sees migration "as a complex process in which economic, political, social and cultural factors all work together".

Skeldon (1997, p. 2) defines migration as a "shift in place of residence from one area to another" and development as "a growth, an evolution, an advancement". However, it appears that the relationship and impact on each other is highly complex and continues to be contested (Gamlen, 2010, 2014; Portes, 2008). Portes (2008, p. 19) writes that migration can be defined as "a symptom of underdevelopment but also as a cause of its perpetuation"; "as a short-term safety valve" and; "as a potential long-term instrument for sustainable growth”. Recent literature supports that although migration can be caused by a lack of development in the sending countries, migration may also be a key driver in the 
transformation of these countries (Stark, 2004; Stark, Helmenstein, \& Prskawetz, 1997).

In order to understand the impact of migration on development, it is crucial to understand foremost the importance of migrant agency (Kapur \& McHale, 2005, p. 12). It should be assumed that people will do what is best for them or their family to improve their living, well-being and income (Bodvarsson \& Van den Berg, 2009; Castles \& Miller, 2009) but decisions to migrate are subjected to "cultural, social and political" (Cohen \& Sirkeci, 2011, p. 78) factors that are “related to and influenced by a mover's status, gender, ability, household, and community - not just economic desires" (Cohen \& Sirkeci, 2011, p. 78). Nevertheless, Skeldon (2008, p. 2) points out that we shouldn't expect the individual migrants to drive development. It is important to consider that migration is just one variable amongst many that can affect development (Appleyard, 1989, p. 497; Castles \& Miller, 2009, p. 77).

\subsubsection{Brain circulation}

The potential for migration to benefit development is additionally more complex when skill and education is added to the equation.

The 'brain drain' concept has been at the core of migration and development research as theorists research whether emigration of the educated is detrimental to the development of the countries or whether it is possible to have a 'win-winwin' situation where sending countries, receiving countries and the individual migrants can benefit from population movement (Castles \& Miller, 2009; Kapur \& McHale, 2005).

In the literature and in development practice, human capital is a key component for economic development (Boulding, 1968, p. 109; Williams \& Baláz, 2008) :

"Human capital is increasingly seen as a, if not the, key to economic growth and competitiveness, and national states have sought out various strategies to enhance what has come to be seen as a vital resource" (Williams \& Baláz, 2008, 
p. 19)

However, in many developing countries, the potential benefits of human capital on a society may be impacted by the possibilities of migration. Adams and Douglas (1968, p. 1) states that "human capital, as a strategic resource, is flowing out of economies where it can make the greatest contribution to human welfare, and into economies already well-supplied with trained, capable, scientific and administrative personnel". Nowadays, this is still the case.

It appears that a higher proportion of migrants are educated and sending countries are losing their 'best and brightest' (Adams Jr, 2003; Kapur \& McHale, 2005). This movement has arguably been perpetuated by receiving countries through their 'selection bias' as their immigration policies allows them to take the best (Kapur \& McHale, 2005, p. 21). Studies have shown that selection bias policies to satisfy the human resources shortages in host countries have in fact perpetuated global inequality (IOM, 2005, p. 175). Similarly, Castles and Miller (2009, p. 65) believe that the "loss of qualified personnel from less developed countries can lead to economic stagnation, waste of the public funds invested in higher education, and depletion of tax income."

In addition to the harmful effects of brain drain, many countries lose on investment if the state provides an aid to the students to invest in their own education (Boulding, 1968; Kapur \& McHale, 2005, p. 29) unless students felt like it was a moral duty to stay (Boulding, 1968, p. 114). For countries where higher education needs to be obtained abroad, Kindleberger (1968) expresses that education would have uncertain consequences for the sending countries. In many cases, graduates may not return and will use their skills elsewhere, or will return with skills that cannot be applied successfully in the home country (Kindleberger, 1968, p. 136). Kindleberger (1968, pp. 136-147) also expresses concern over 'adjustment' of the students in the host country and explains that not all students will succeed in studies and be able to contribute to development upon return. 
Conversely, recent studies have suggested that brain drain may eventually be conducive to growth and development (Adams Jr, 2003; Stark \& Wang, 2002). The 'brain gain' theory suggests that even if developed countries continue to take the best, the 'prospect' of finding employment elsewhere acts as an incentive for education (Fan \& Stark, 2003, p. 28; Kapur \& McHale, 2005; Mountford, 1997; Stark, 2004; Stark et al., 1997; Stark \& Wang, 2002; Vidal, 1998). This could then "enhance welfare and nudge the economy towards the social optimum" (Stark, 2004, p. 15; Stark \& Wang, 2002, p. 29), "increase the long run income level and income equality" (Mountford, 1997, pp. 302-303) and "can lead the source country out of an under-developed trap" (Vidal, 1998, p. 589). Additionally, more people are likely to stay or return upon the realisation that their wages are lower for unskilled labour in the destination country and will further incentivise them to invest in education and skill at home (Stark et al., 1997). Even so, experienced unskilled migrants gathered abroad will also be valuable to the home countries upon their return (Stark et al., 1997).

Although the theory of brain gain would be the solution to the human capital dilemma, the evidence is limited. Schiff (2005) finds the argument that brain drain could benefit the development of society as exaggerated and demonstrates that the returns to education are not as high as claimed. Firstly, people may be deterred by the uncertain benefits provided and the high costs of education and secondly, incentives to acquire education will not deter unskilled people from migrating (Schiff, 2005, pp. 30-31). Additionally, brain gain could result in brain waste and unemployment of educated people in the sending countries (Schiff, 2005).

Adding to the debate, studies note that skill drain could still benefit sending countries through transfers from migrants such as remittances and knowledge transfers. In particular, higher remittances of the skilled may influence sendingcountry development (Faini, 2007; World Bank, 2003) and remittances as a social insurance may soften the impacts of poverty, particularly during financial crises (Kapur, 2004). Yet brain drain remitters may already be part of wealthier families and less likely to remit (Faini, 2007; Kapur, 2004; Niimi, Ozden, \& Schiff, 2010). 
Given that remittances are usually private transfers (Carling, 2008, p. 54), there is little proof that remittances would not directly benefit the poorest families (Skeldon, 2008). And although remittances may provide temporary labour work for the poorer communities, they are not a replacement of financial aid (IOM, 2005, p. 49; Kapur, 2004, p. 11). Additionally, sending countries could benefit from knowledge transfers from educated migrants. However, Siar (2012) stresses that a lasting transfer of knowledge is largely dependent on factors such as the stability of Diasporas or networks in the host countries. There remains much speculation as to whether remittances and knowledge transfers can offset the losses from brain drain (Faini, 2007; Kapur, 2004; Siar, 2012).

However, the majority of the brain gain and brain drain theory at a global scale is based upon income calculations of migrants and the idea that wealth is the main driver of migration, as remarked by Gibson and McKenzie (2011). This research may find that brain drain or brain gain is influenced by other factors.

\subsection{Small states, the Pacific and migration}

\subsubsection{A culture of migration}

According to Connell (2007, p. 121), migration has been growing in the Pacific since the 1960s. Migration is now of "great and increasing significance for the development of Pacific island states" (Connell, 1990a, p. xi) and has helped the islands find economic opportunities elsewhere (Connell, 199ob, p. 11). Migration from the Pacific has also been determined to be an "extension of island life" and an inevitable occurrence (Connell, 2008, p. 1021).

The relationship between migration and development in the Pacific is highly complex. The motives to migrate vary from changing of values, as a response to social and economic inequalities, for education and to find employment with higher 'prestige' as a result of the increased contempt towards agricultural work (Connell, 199ob, p. 3). From the literature, it is evident that migration has impacted the islands to varying degrees at the household and national levels. It 
has simultaneously been used as "a source of valuable remittances" (Connell, 2007, p. 121), an "outlet for the population pressures" (Maclellan \& Mares, 2006, p. 138) and a strategic "semi-permanent safety-valve" as a response to underdeveloped structures (Connell, 2010, p.121; Connell, 2008). Literature in the Pacific has stated that the motives to migrate and the impacts of migration are intertwined as the factors pushing migrants away will in fact perpetuate the same factors (Connell, 199ob, 2010; Zimmer, 1990). Different findings in the literature present that migration has simultaneously acted as a driver of and a consequence of economic development in the Pacific (Connell, 1990b, p. 2).

In this case, whether remittances can assist development in the Pacific has been a source of debate. Brown and Connell (2004, p. 2193) see remittances as a possible component to "compensate for the skills drain", along with return migration and economic investment. In the Pacific, remittances are perceived as a complement or substitute for financial development assistance (Bertram, 2006; Maclellan \& Mares, 2006). Furthermore, due to kinship communities, despite being private transfers, remittances would have a wider impact on the communities as a whole (Fairbairn, 1993). However, the sustainability of remittances as development assistance could be challenged by changing mentalities causing kinship solidarity to decline in some Pacific nations (Connell, 1990a; James, 1993; Morton, 1987). As a result, remittances have been used to benefit consumerist wants within families (Finau SM, 1993) and have led to 'pockets' of wealth in the same villages (Fairbairn-Dunlop, 1993).

Moreover, the interest to remit might fluctuate depending on the sustainability of the networks abroad and back home. Loomis (1990) establishes that remittances from New Zealand to the Cook Islands were less prominent from younger people and generally declining due to the changing structures. Connell (2010) also believes that willingness to remit decline as more people join families overseas and if second generation migrants do not forge the same connections. Rallu (1994, p. 210) suggests that this growing dependency on remittances may actually lead to more migration in order to perpetuate the flows. Yet, remittances will also depend on the number of remitters per family and the number of family 
members at home (Poirine in Bertram, 2006).

For some economies, remittances are not as high because of the limited differences between standards of living at home and overseas. Although remittances assisted the purchase of goods or airfares in Niue, they were not the foundation of their standard of living due to access to government wages or premiums (Matheson, 1989 cited in Connell, 2008, p. 1030). In this case, Ogden (1994 cited in Connell, 2008, p. 1030) referred to this economy as a MIAB (Migration, Aid and Bureaucracy) rather than a MIRAB. According to Poirine's model on the altruistic motives of remittances, introduced in Bertram's (2006, p. 8-9) paper, remittances will vary depending on the relative 'real consumption' for the migrant and for those back home.

In the Pacific, although networks have been invaluable for the perpetuation of remittances and have helped individual migrants settle and find employment (Matheson, 1989 in Connell, 2008), they have also contributed to outmigration; “"my family have gone therefore I shall have to join them; I cannot bring up my children here without a babysitter"' (Connell, 2008, p.1032).

\subsubsection{Brain circulation}

Sharrod (1993, p. 21) found that the respect of education and the idea of "betterment" that comes with it has been a common 'push' for island populations to metropolitan centres. As Brown and Connell (2004) stated, tertiary education is an additional cause for migration for young people from the Pacific, particularly for smaller states with limited tertiary education facilities. Although this migration has been outside of the region, new university facilities, such as the University of the South Pacific, have increased movement within the region (Brown \& Connell, 2004, p. 2194; Hau'ofa, 2008, p. 37) However, as highlighted in section 2.2.2, education abroad may not always be beneficial for the sending countries.

According to Brown and Connell (2004, p.2193), "the role of human resources is 
central to development, especially in small states, and the limited availability of skilled human resources can be a constraint to development”. For small island states in particular, brain drain is an important concern and has been significantly detrimental to their prospect for development (Beine, Docquier, \& Rapoport, 2008; Beine, Docquier, \& Schiff, 2008; de la Croix, Docquier, \& Schiff, 2014; Gibson \& McKenzie, 2011, 2012; Reddy, Mohanty, \& Naidu, 2004). The literature has highlighted concerns over a limited probability of return from emigrants or investment back home (Ahlburg \& Brown, 1998; Beine, Docquier, \& Rapoport, 2008; Beine, Docquier, \& Schiff, 2008; Gibson \& McKenzie, 2011). Indeed, according to Schiff (2005, p. 31) places with severe brain drain where outmigration is higher than $15 \%$ are much less likely to receive positive returns. In a sense, brain drain has become the new culture of migration; "migration has become more skill-selective, and the brain drain increasingly exemplifies patterns of migration from islands" (Connell, 2010, p. 121).

The Pacific region is also subjected to a skill drain of the best and brightest. In fact, Maclellan and Mares (2006, p. 138) points out that the brain drain was being perpetuated in the Pacific by "immigration policies of developed nations (that) favour those with skills and high levels of education”. Brown and Connell (2004) explains that skilled health professionals from the South Pacific were particularly drawn to metropolitan countries because their qualifications provide them with easier entry. These qualifications were prioritised in immigration policies in order to address the shortages of health workers in sending countries (Brown \& Connell, 2004, p. 2194). However, Brown and Connell (2004, p. 2195) also highlights that immigration of the skilled populations often led to 'brain waste' as qualifications were not recognised in their destination.

Although evidence shows that migration and the brain drain predominantly occur as a result of limited employment opportunities in the migrants' home country (Benjamin, 1993; Castles \& Miller, 2009; Rallu, 1994), emigration has now created a gap in the number of skilled workers available to fill existing employment (Brown \& Connell, 2004). As a result, the brain drain means working populations in the islands continue to be under-skilled and can 
sometimes lead to positions having to be filled by more expensive foreign expatriates (Rallu, 1994, p. 210). For instance, in Samoa, people in high-level government jobs were sometimes under-qualified (Rallu, 1994). Maclellan and Mares (2006, p. 138) also identify that skill drain raised the unemployment at home because of the limited employment opportunities in the "formal wage sector" for the lower skilled populations.

For instance, migrants may not return due to low salaries or high loans that need to be paid (Benjamin, 1993). Additionally, sometimes qualifications acquired are not suited to the context if they return. Brown and Connell (2004, p. 2193) writes that in the case of health workers "there is a continued need to ensure that training and education are relevant to the particular situation of small states, in terms of local constraints and requirements." Furthermore, Connell (2008, p. 1026) cites studies referring to a 'training conundrum,' or 'diploma disease' (Dore, 1976 \& Matheson, 1989 cited in Connell, 2008, p. 1026) where migrants were in a sense overqualified for specified employment at home. Connell (2008, p. 1026) also found that people sometimes were too specialised in certain fields and had "skills of limited utility" when Niue needed "generalists and multi-skilled" personnel. Furthermore, Benjamin (1993, p. 258) mentions that students may also acquire skills or diplomas that aren't recognised back home, meaning their chances of success in a field that they are trained in is slim. Moreover, Connell (2008, p. 1026) adds that students were less likely to return the longer they remained overseas. Though, with education and training overseas, islands may impose bonding times requiring a return of the students post-study for a determined length of time to practice their acquired skills (Connell, 2008, p. 1026).

As a result, Pacific island nations do not get a return on their investment in the training of their labour force since they are being lost to developed nations. Brown and Connell (2004, p. 2194) expresses that the training of health professionals in particular was costly and replacing their loss of trained professional would also be expensive. Replacements would also not necessarily have the "appropriate skills, languages and cultural sensitivity" and could create 
problems and affect the development of "healthy islands" (Brown \& Connell, 2004, p. 2194). In Niue, Connell (2008, p. 1026) finds that the training provided was prioritising the education of academics over tradespeople. Employment in engineering, electricity, carpentry for instance was a sector experiencing shortages on the island and required immigration of professionals from outside the island. Conversely, Connell (2010) emphasises that to control the loss of workers was not on the agenda for governments such as Tuvalu, Kiribati, Tonga and Samoa as they continued to train more workers than required in the islands.

\subsection{To increase return or control emigration?}

Understanding the complexity of migration and the factors that may influence movement is crucial but how this information is considered and managed is even more important (De Haas, 2012; Skeldon, 2008). This is furthermore made more complex as sociologists, economist, politicians and policymakers, for instance, will all have different opinions on the causes and impacts of migration, yet all be involved in the theoretical framework and outputs (Bodvarsson \& Van den Berg, 2009, p. 27) and the models used to explain migration would then have different implications on policy (Massey et al., 1993, p. 463). Recently, many theorists call for a more positive view on how migration can help development, rather than seeing it as a problem (Bakewell, 2008, p. 126; Castles \& Miller, 2009, p. 65) and many call for greater inclusion of migration into development policies in order to forge these positive impacts (Castles \& Miller, 2009; Katseli, Lucas, \& Xenogiani, 2006). In fact, Skeldon (2008, p. 16) emphasises that "should be recognized as an integral part of the development process itself and planned for accordingly".

How migration is managed to benefit development differs depending on the context and whether migration has a positive impact on development or whether it is detrimental. In light of recent findings, theorists recommend enabling migration whilst maintaining a certain control. Schiff (2005, p. 32) suggests that countries need to "slow down or stop the exodus of skilled labor", while others 
argue that countries need to maintain migration with a policy to control and restrict migration (Fan \& Stark, 2003; Stark, 2004, p. 16; Stark \& Wang, 2002). Others have argued that restricting migration may have a long term detrimental impact if migration is crucial to maintain livelihoods and socioeconomic wellbeing (Deshingkar \& Grimm, 2005). And more recently, policies have tried to implement or encourage circular migration, temporary migration and return migration (Agunias, 2006; Cassarino, 2004; Docquier \& Rapoport, 2004; Docquier \& Schiff, 2009; GCIM, 2005; OECD, 2008; Ruhs, 2006; Vertovec, 2006). Circular, temporary and return migration have been most prominent in recent literature. Implementation of such migration could be done through increasing incentives to return or organising restrictive migration policies in concordance with receiving countries such as temporary work permits (Agunias, 20o6; Ruhs, 2006). Although Castles and Miller (2009, pp. 68-70) warns of difficulties to implement such programmes which "would require major changes in attitudes and policies", may cause loopholes for "worker exploitation" and may not encourage the intended impact on development.

In cases where controlled migration is encouraged through investing in development, research showed an increase of immigration in the short term (Castles \& Miller, 2009, p. 75; Massey, 1988). Castles and Miller (2009, p. 74) places doubt on the argument that migration could be addressed through increased development as it is not the poor who tend to migrate. Migration may not necessarily decline as populations will have greater access to resources to do so (Castles \& Miller, 2009, p. 75). Yet, evidence of increased return of skilled migrants was evident in places such as India and Taiwan following increased economic growth (Castles \& Miller, 2009, p. 65; Fan \& Stark, 2003; Findlay, 2002). However, in the short term, countries suffered from extreme brain drain and educated unemployment (Fan \& Stark, 2003, p. 4).

Most importantly, however, it is crucial to ensure that policies or strategies in light of migration and the brain drain must fit within the context it is meant for to allow a 'win-win-win' situation between all parties involved (Castles \& Miller, 2009, p. 75). This would require coordination between the sending and receiving 
countries as well as motivation by all parties involved (Beine, Docquier, \& Schiff, 2008, p. 13; Castles \& Miller, 2009; GCIM, 2005; Ruhs, 2006).

In the Pacific region, there is unclear direction as to how policy can tackle migration in the region and in terms of which factors need to be taken into consideration. Benjamin (1993, p. 258) calls for a way in which the Pacific could keep "trained and skilled manpower resources from leaving the islands" and Brown and Connell (2004, p. 2193) believes that islands should use development policies to encourage "return migration, alongside retention and recruitment". Similarly, Niue is seeking return migration and immigration to tackle its rapidly declining population (Connell, 2008, p. 1021). For instance, when the French Pacific was experiencing internal migration within the territories, authorities had implemented policies and agreements to "prevent migration" and "encourage return migration" (Baudchon, 1992, p. 333). While others have sought to increase strategic development to encourage return, in some cases, policies to limit migration may not be an option. Guam would benefit from a policy tackling emigration but it may not have the authority to do so (Bettis, 1993, p. 294).

However, in some contexts, return may not be the answer for development. Return may in fact be more disruptive politically, economically and socially for the region. As previously highlighted, migrants may return with qualifications and experiences that are not appropriate or required in the context (Kindleberger, 1968). For instance, high-skilled migrants are not necessarily the "most appropriate personnel for the conditions where the development needs are greatest" (Skeldon, 2008, p. 10).

The need for return is closely related to the role of migration in Pacific Islands. In the Pacific, where migration is used as a safety valve, policies such as 'guest worker schemes' or 'seasonal employment' (Connell, 2010; Maclelland \& Mares, 2006) may be a possible solution to skill losses and unemployment youth bulge in the islands (Maclelland \& Mares, 2006). Migration could even be a "substitute for development" to reduce the burden of having to create jobs (Connell, 199ob, p. 10). 
Connell (199ob, p. 21) argues that in some Pacific Islands, migration has provided a choice to conserve and disengage with global modernity and has "enable(d) some resurgence of self-reliance and cultural continuity" (Connell, 2010, p. 125). According to Connell, migration acts "as a force of conservation and dissolution" (Connell, 199ob, p. 21). Impacts of migration on culture is a common theme in Pacific migration literature (Bettis, 1993; Brown \& Connell, 2004; Connell, 1983, 1990a, 199ob, 2003, 2007, 2008, 2010; Sharrod, 1993).

Sharrod (1993) notes that in the Pacific, people do not only migrate for higher paid employment, rather the prevalence of culture in society - particularly a person's status- could drive them to places "that makes them feel wanted (in some cases, you might be a brain surgeon but if you're not from a chiefly family you're a nobody)" (Sharrod, 1993, p. 21). Moving abroad, in a way, is an opportunity through which an individual can "best fulfil [their] expectations" if cultural factors at home do not allow it (Sharrod, 1993, p. 21). Sharrod states that because of this, return migration might not always be a concern or even an objective for a Pacific society. In another sense, emigration is a way of preserving culture; "a traditional society wanting to "develop" indigenous folkways might be extremely glad to see modernised youth disappearing over the horizon!" (Sharrod, 1993, p. 20).

Similarly, Connell (2010, pp. 123-124) saw that older people were losing power and representation in society and were not benefiting from modern changes brought by younger generations; "the visions of the young are in conflict with the values of the old; there are tensions and contradictions between the indigenous and industrial worlds and great stress is placed on the maintenance of the social economy" (Connell, 199ob, p. 17). In this way, migration provides a choice for those to "assert and value the strengths and culture and locality" to stay while others are drawn by the "symbols of modernity" (migration) to leave (Connell, 2010, p.126).

Additionally, upon return, students can be faced with stigma and difficulties; "often welcomed in theory, but spurned in practice" (Connell, 2008, p. 1026). In 
Niue, returnees may be seen as greedy and are resented when they earn higher wages over those who "remained and demonstrated their loyalty and commitment" (Connell, 2008, p. 1034). Some returnees may also feel that they “act western" and struggle to assimilate back into society (Ritterbush \& Pearson, 1988 in Connell, 1990b). In other cases, migration could be seen as a "rite of passage", in which case, "return migration is often an admission of failure" (Connell, 1983; 199ob, p. 19).

Return may then have a destabilising effect on the structure of community life when migrants bring new, ill-fitting ideas to the region (Appleyard, 1989, p. 497). As an example, Guam found that policies to tackle immigration in alignment with labour shortages, economic growth and profit would overlook more crucial sociocultural stability factors (Bettis, 1993, p. 293). Sharrod (1993) states that it is our "Western packaging of debate" that conditions us to think brain drain is a negative for society. In the case of the Pacific, return migration or controlled migration may not be the solution.

\subsection{Reviewing the gaps}

The literature has demonstrated that migration, development and education is highly context dependent and requires empirical research to support claims. Bodvarsson and Van den Berg (2009, p. 27) highlighted that even today "there is still a big gap between theory and empirical work, and much needs to be done on the theoretical side of this literature to bridge that gap”.

The literature review has highlighted unclear answers on the subject of migration and development along with the impacts of skilled migration on sending countries, and has further emphasised the importance of understanding the context in order to inform conclusions. Particularly, the review has indicated that the research should look into the different possible socio-economic and political roles of migration and education in Wallis and Futuna.

This chapter and the previous chapter have uncovered clear themes and gaps for 
this research to explore the situation in the territory in relation to the brain gain'/ 'brain drain' concepts. Much of the literature above will help inform the research and subsequently analyse the findings. This review has presented the research with key underlying questions for the study in terms of migration, education and development:

What are the initiatives to support education and training of Wallisians and Futunans and are they successful?

- What opportunities are there upon the return of students?

* Are there limiting factors for the return of students and possible economic activity in the territory? 


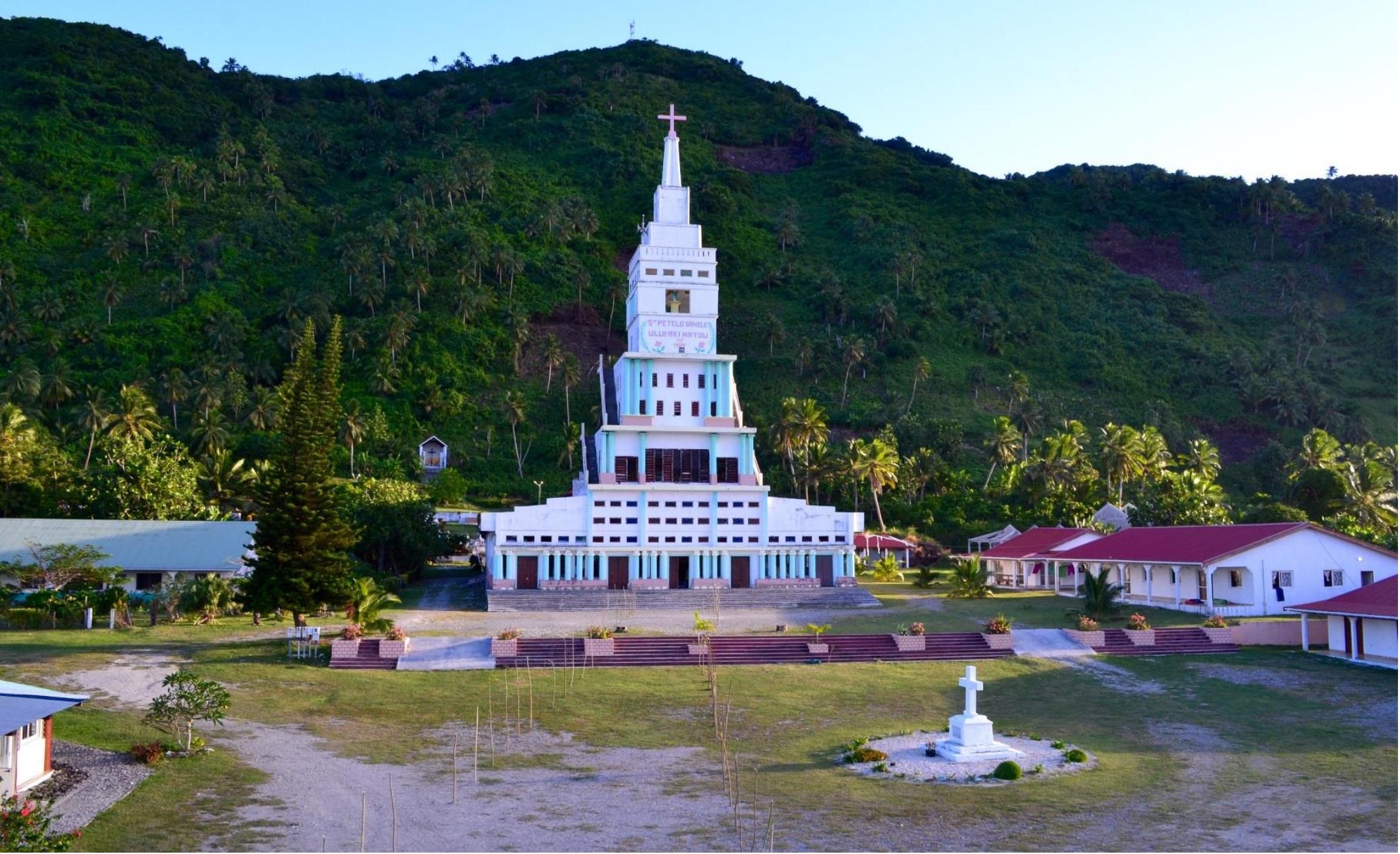

\section{Basilica Saint Pierre-Chanel, Futuna}

Chapter Three:

Photo by author

Methodology and Fieldwork 


\subsection{Introduction}

This chapter explains how the topic of this research was explored in the field. The research is a constructivist grounded theory qualitative study based on Talanoa interviews. The methods used in fieldwork were crucial in providing the research with the tools to understand and analyse the topic in question. The research was carried out over a two-month stay in Wallis, Futuna and New Caledonia where I was able to interview participants, observe and experience living there.

This chapter uncovers the research journey from the design stage to the analysis, including the difficulties encountered along the way.

\subsection{Methods}

\subsubsection{Worldview and research approach}

This research is examined through a Constructivist or Social Constructivist or interpretivist (Willis, Jost, \& Nilakanta, 2007) epistemology. This worldview supports the idea that reality is a social creation (Berger \& Luckmann, 1967) and can only be understood within the context of the topic of research (Willis et al., 2007, p. 54). The idea of constructivism is that "individuals develop subjective meanings of their experiences" (Creswell, 2013, p. 8), making participant involvement invaluable in social research. Moreover, constructivism ensures the researchers acknowledge that the outcomes of the research will be subject to their actions and interpretations of the findings will be influenced by their background and prior knowledge construct (Creswell, 2013).

The research design and analysis is based on the Constructivist Grounded Theory (CGT) method. In the more general Grounded Theory approach (Willis et al., 2007, p. 306), data is analysed throughout the collection process with the aim of developing a theory. Grounded Theory allows flexibility in data gathering methods and acknowledges that a particular lens or theory may not be effective 
in explaining the topic in question. As was evident in the literature review chapter, academic research on this particular topic is limited and thus to apply a development theory to the research would have perhaps directed the research in an ill-fitting direction and influenced the interpretation of the data. In particular, CGT provided space for discovery and observation, as it "places priority on the phenomena of study and sees both data and analysis as created from shared experiences and relationships with participants and other sources of data" (Charmaz, 2006, p. 130). Thus, the research does not necessarily require a 'generalizable' theory to emerge (Willis et al., 2007), rather evolving themes may at the end be attached to different realities and research conclusions.

\subsubsection{Talanoa}

The advantage of qualitative research methods is that they provide the opportunity for researchers to be immersed in the field and gain a holistic understanding of the phenomenon. I chose to conduct research using qualitative research methods as I wanted to fully grasp what is happening, why it is happening and through which means (Brikci \& Green, 2007, p. 3). I believe this could only be truly achieved through hearing the opinions of local observers of the phenomenon to help 'describe, explore or explain' (Stewart-Withers, Banks, McGregor, \& Meo-Sewabu, 2014). Indeed, as Stewart-Withers et al. (2014) noted, and in the light of newer development thinking, there is a need for greater participation where local voices must be considered in order to inform development policies and theories. In this research, opinions and interpretations from interviewees provide a crucial foundation for understanding the impact of migration and education in Wallis and Futuna.

To support the idea that knowledge is situated in time, place and context, it seemed crucial to use a method specific to the Pacific. I decided to use the widely emerging Pacifika interview method known as Talanoa. It is seen as culturally appropriate and most effective for research in the Pacific region (Farelly \& 
Nababa-Bobo, 2012; Otsuka, 2006). The Talanoa method is embedded in social constructivism where relationships between researchers and individuals are the core ingredient to the findings and open-dialogue exchanges are the medium through which they are gathered (Farelly \& Nababa-Bobo, 2012, p. 3).

Literally translated, Talanoa means to talk about "nothing in particular" (Farelly \& Nababa-Bobo, 2012, p. 2; Otsuka, 2006, p. 3) but it is actually a method through which participants can "tell stories or relate experience" without relying on a "rigid framework" (Vaioleti, 2006, 23). Through this method, the barriers are removed and discussions are "resistant to rigid hegemonic control" (JohanssonFua, 2008 cited in Fairbairn-Dunlop \& Coxon, 2014, p. 16). It's a platform where stories can be shared "openly and without concealment, and always with respect for one another" (Halapua, 2000, p. 2).

The method is not only important for the research due to its cultural relevance, but also because it aligns with the social constructivist and grounded theory approaches. This method gives the participants the power to mould the research, rather than the researcher extracting what they deem important.

To support this method, I had prepared open-ended, non-leading questions and prompts to guide discussion. The questions revolved around the research questions outlined in chapter one. The questions and vocabulary used in the interviews were adapted to different participants. The Talanoa method was used in focus groups and individual interviews alike.

\subsection{In the field}

Experience with the Talanoa method was positive overall. It enabled relationships to develop as our conversations uncovered an array of relevant topics to the research which were explored in more depth than I could have gathered in a structured or semi-structured interview. Here, participants had the freedom to touch upon all topics that they thought would be of interest to the research. I felt that this more relaxed technique of interviewing allowed the 
participants to be more involved, as the conversation often led to an exchange of ideas. This is in fact encouraged in Talanoa (Halapua, 200o).

Separate Talanoa method focus groups were conducted with high school students, teachers and returning graduates. Initially, I wished to conduct PRA workshops such as diagramming but they found this suggestion 'childish'. I met up with the same group of students on three separate occasions in total as it was important not only to build relationship, but also to be able to build on the information shared in previous meetings. Unfortunately, different factors inhibited a Talanoa discussion and even a semi-structured styled interview, which ultimately affected the information collected. One of the issues was timing in the year as the students had only just started their final year at high school and they had not thoroughly thought about their future path. Another factor that I was warned about was the role of power and 'status' on who has the right to speak within the groups, which meant that some students were more open to discussion than others. Despite these issues, observations from these focus groups were interesting for the research.

\subsubsection{Participants and recruitment}

Initially, I had planned that a larger proportion of my interviews would be with school children and university students and complemented by a few interviews with government officials and NGO workers. This was in order to see whether students' perceptions shifted as they got older. Interviews with government officials and NGO workers would then confirm or contradict the information but could also provide explanation on the development future of the territory.

However, in the field, it became apparent that in order to explore the forces that drive the phenomenon in Wallis and Futuna, I needed to understand in some depth how the territory operated. Therefore, my research had to gather input from as many people with different viewpoints. Participant recruitment changed throughout the research and I would take up the opportunity to talk to anyone that was available and willing to be interviewed, rather than targeting specific 
people. In total there were 60 participants and 45 separate recordings. I interviewed local people and metropolitan expatriates from a variety of different backgrounds such as students, teachers, returnees, government officials, civil servants.

From observation, it was evident throughout the research that the connections and networks I made primarily dictated whom I met with and thus had an important influence on the research process.

In Wallis, I remained in a network of 'bureaucratic elite' and it was difficult for me to find participants in other fields. For example, I found myself caught in a network of government people and working returnees, rather than people who were struggling to find a job or had not succeeded in their studies and were forced to return. On the other hand in Futuna, I had a different experience. I happened to meet a very different group of people than in Wallis, which led me to younger participants from different backgrounds.

This use of networks could be seen as a negative factor in the research. For instance, sometimes I felt that people referred me to other potential participants that met the criteria they thought I was looking for, which in a way gave them the power to direct me to participants who perhaps had similar opinions to them.

Although it is important to acknowledge these issues when it comes to using networks in the field, my connections were actually crucial as they defined and shaped the research. If I had not used people's help in finding participants, I would not have been able to meet as many participants.

\section{In Wallis}

Prior to leaving for Wallis, I emailed people on the ground using family connections who recommended potential participants to contact. I then relied in turn on the participants' networks to find more participants. It appeared that I was able to meet with more government workers initially as I was often referred to other government workers for interviewing. 
Here, I met with Government officials working at the Administration and at the Territorial Assembly, high school students, teachers and recent returnees who were working or looking for work in a range of fields in the territory.

\section{In Futuna}

I was put in contact with someone who was in charge of scholarships and helping students apply for university. Due to time constraints, I was given a desk and young returnees came to talk to me progressively throughout the day during their free time. Although this was a great way for me to get as much information in a short amount of time, I felt that this was not in line with my research approach and interview method (Talanoa) as I was not able to have a relaxed conversation or build a relationship with the participants. In this case, the interviews were more semi-structured and participants were generally young people who were working at the Administration and the Territorial Assembly. On my last day in Futuna, a friend took me around Futuna to visit people. This enabled me to gather a range of different perspectives from young people who had found work, some who were struggling and even some high school students.

\section{In New Caledonia}

In New Caledonia, I was able to meet with two key people from Wallis who had moved to Nouméa to pursue education or employment opportunities.

\subsubsection{Consent and anonymity}

Despite using a consent form stating that all interviews would be kept confidential and they would remain anonymous, there were aspects of this that were out of my control. In such a small community networks are strong and everyone knows each other. Often in my interviews, participants wanted to know whom I had met with, or in some cases, they knew whom I had met with. Participants would sometimes either praise or criticise other participants, which not only made it difficult to analyse my data objectively, but also meant that I had to be cautious when quoting participants in this thesis. Although in my 
ethics and consent forms I requested that I be allowed to refer to people by their profession, organisation, or school for example, I have decided since then that doing this may reveal too much. Given that some content in the interviews is personal and participants specifically requested that their interview remain anonymous, I decided to not disclose any information about the participants.

\subsubsection{Language}

Although the vernacular languages are more widely spoken in the household, French is more prominent in the workplace and in schools. The younger generations in particular are bilingual in French and Wallisian or Futunan. For this reason, all interviews were conducted in French. I did not feel the need to use interpreters or translators as I presumed that my participants would be comfortable speaking French for the interviews. What I hadn't anticipated, however, is that having a good command of the French language in Wallis and Futuna seems to be specific to the young, the educated and the wealthy, particularly to those who had the opportunity to migrate, which meant that my range of participants may have been limited. Unfortunately, I was unable to speak to the older Wallisian or Futunan generations (priests, chiefs etc), those who did not have a positive place in society, or the poorer populations.

In spite of this, because most of my informants were students, government officials and recent returnees, there were rarely any language issues as they spoke perfect French. However, my research possibly unwittingly gave a voice to those who were already privileged and had a voice in society, rather than those who were not often heard because of their status or command of the language.

\subsubsection{Recording}

I used a voice recorder in the interviews. Only two participants were not comfortable with being recorded due to the nature of the topic so I took notes instead. During recorded interviews there were no issues but I noticed that once 
the recording device was turned off, participants were more open and I was able to gather additional information during that time.

\subsubsection{Transport and accommodation}

One of the main initial issues in my research is that I hadn't anticipated that there are no public transport or taxi services in Wallis and Futuna. As I didn't have a driver's license at the time, I wasn't able to hire a vehicle. The hotel was however situated a two-minute walk from government headquarters and I was able to walk to the meetings held there. In other cases, I was picked up by the participants or given a ride by friends.

Although it would have been beneficial to live in a homestay during the research to help my understanding of the way of life in Wallis and Futuna, staying at the hotel enabled me to form my own opinion through what I was discovering in interviews and through general observations. Had I stayed with a host family, I would have been influenced by their beliefs and opinions. I would also have been associated with that family, and their connections, which may have affected participants' perceptions of me and the research.

\subsection{Reflexivity}

\subsubsection{Positioning myself in the research}

Throughout the research process I had to be aware of my "unstable and not fixed" positionalities (Sultana, 2007, page 382) to be able to negotiate and avoid negative influences on the research outcomes (Schevens \& Mclennan, 2014, p. 5). This is particularly true in the Pacific as Vaioleti (2006, p. 22) has explained: "the participants will behave differently depending on the age, gender, cultural rank or community standing of the researcher". Thus, prior to conducting research, it was important to acknowledge my positionality. 
I am a 24-year-old papalagi (western) woman, originally from the United Kingdom. I grew up in Belgium, Vietnam and Thailand and I have lived in the United Kingdom, Spain, Fiji and New Zealand since graduating from high school. I studied International Relations and Spanish at the University of Exeter in UK, specialising in Middle-Eastern politics.

I am no stranger to migration having experienced it time and time again myself. Currently, I have an older brother in Cambodia and a younger brother studying here in Wellington. Throughout my life, my family and I have been constantly moving and travelling. Contrary to the topic of the thesis, I migrated 'home' for education and had an Erasmus year in Spain in my third year. My move to the UK was not easy as I felt like a foreigner in my own country.

I am bilingual in French and English. I learnt English from my parents and attended French-speaking schools. As a result of migration, I have acquired an 'international' French accent. I feel it is important to mention this point to demonstrate how my positionality changed or appeared complex in different contexts. Despite my effort to make explicit my positionality in the field, to some I was seen as French and to others I was a New Zealander. Furthermore, I found that my familiarity with the complexity of the French system of education was a crucial asset during the research.

In 2013, my parents moved to Fiji and since then, Fiji has become my home. In the summer of 2013 - 2014 I interned at the United Nations Development Programme Pacific Office where I was exposed to the immense diversity of the Pacific Region. During this internship, I was provided with a tremendous opportunity to increase my awareness and understanding of the Pacific, from its issues to its assets. My interest in the Pacific continued to grow throughout my masters' Part 1 year. In the summer 2014-2015 I interned at the Pacific Cooperation Foundation in Auckland where I discovered a new angle of development in the Pacific: business and trade. These experiences have brought me where I am today but I still had had very little exposure to the French Pacific. To understand the diversity of the Pacific Region, I wanted to explore this part 
of the region. Prior to the research I knew very little in Wallis and Futuna and I was a complete outsider.

During field research, I endeavoured to make note of my positionality in order to avoid negative effects and diffuse power dynamics (Chacko, 2004). Understanding my positionality helped as I noticed how it affected whom I met with, how I was perceived and the relationships I could develop. This was particularly true in terms of age, gender, language and me being papalagi. However, to determine whether these were advantageous for my research or not is difficult. My age, for example, enabled me to adapt and relate to the participants in some cases but in other cases was seen as reinforcing or relegating power.

Furthermore, the fact that I was an outsider seemed to have different impacts in different contexts. For example, in the field it was evident that I was seen as papalagi and throughout the research process I was constantly trying to negotiate with my neo-colonial researcher appearance. Concerns that were brought up in interviews about the difficult relationships between the indigenous communities and the papalagi in the territory made me concerned about my own identity and how I was perceived. Participants revealed that they feared I would misconstrue their stories, take away the information and distort it to tell a story that would suit the research and my own agenda.

It became apparent that, with time, participants' perceptions of me started to change. As a result of building relationships, talking to people about my own stories and disclosing my own identity, participants became more open about sensitive topics. This made me realise that I was progressively losing my outsider papalagi status and that I had in a way been given a new place in Wallisian and Futunan society. 


\section{Example: addressing people}

In the French language, there are two pronouns for 'you' and it is important to know which pronoun is most appropriate to address the other person. The $t u$ pronoun (informal you) is used to address someone younger, a good friend or someone of the same age. The vous (formal you) is used to address a superior, an older person or a stranger, and to show respect. I began by addressing participants with vous unless they were younger. In some cases, I used vous to address the participants however they used the tu to address me. In other contexts, we both used $t u$ for each other but this varied depending on people's preference (if they requested me to), on their age, and on their status. For instance, I was allowed to use $t u$ for the grandson of a previous king who was much older than me. For this research, it would have been best if we were to use the same pronoun, in particular $t u$, as the notion of power would have been less present during the interviews. However, in most cases this was not possible and in some cases, there appeared to be barriers to discussion during the interviews as a result.

Here, my positionality was constantly changing between contexts and the way we addressed each other in the research had an important role in relegating or reinforcing power dynamics.

\subsubsection{Fieldwork Burnout}

Though Scheyvens, Scheyvens, and Nowak (2014, pp. 132-133) recommends "periodic withdrawal from the 'field environment" to fight the "fieldwork blues", I felt as though I could never really escape from the research because of the circumstances. After spending a while in the field, the stress of having to constantly organise interviews, meet new people, and be mindful of my behaviour throughout was tiring. Although I rarely felt unsafe, I was often uneasy about walking out alone, particularly in New Caledonia.

All these factors amounted to fieldwork burnout and although I thoroughly enjoyed the process, there were times when I felt like returning to Wellington to 
recuperate. I believe that these factors are important to take into consideration, as they had an impact on the research process, particularly in New Caledonia.

\subsection{Analysis of the research}

Analysis of the research was ongoing throughout the fieldwork. I used the memowriting and coding methods, as associated with Grounded Theory, both in the field and during write-up (Charmaz, 2006; Urquhart, 2013). Memo-writing is used to prompt the researcher "to analyse your data and codes early in the research process" (Charmaz, 2007, P73) as "memos catch your thoughts, capture the comparisons and connections you make, and crystallize questions and directions for you to pursue" (Charmaz, 2007, p73). Through this method the research becomes an iterative process whereby new themes are being discovered and the researcher is constantly learning about the environment and the participants (Charmaz, 2006).

The data collected from interviews were analysed through the CGT method. First the interviews were transcribed and then, through coding, I was able to organise the material into categories and deduct conclusions (Charmaz, 2006, p.3). I also used diagrams to organise codes and link the material together in order to construct applicable theory (Urquhart, 2013, pp. 106-128).

Writing a journal was an additional way of keeping track of emerging concepts throughout the research and helped me reflect on how they were relevant to the topic. I made note of the participants' contributions and my own observations throughout the process and adapted the emerging concepts as questions in the interviews that followed where appropriate. 


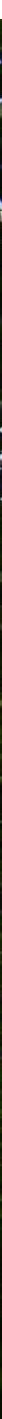

\section{Lac Lalolalo, Wallis}

Photo by author

\section{Chapter Four: Education, employment and culture - insights from participants}




\subsection{Introduction}

Participants in interviews have argued that the need to migrate is 'atavistic' in Polynesia Wallisians and Futunan have been travelling by boat for centuries and is represented by the Wallisian word tavaka (participant 10). Tavaka represents the process of leaving home and landing somewhere new. With tavaka, travellers always return home. Ancestors from Wallis and Futuna would travel all around Polynesia using the stars to navigate and they would always return back to the fenua (participant 10). Nowadays, migration has become a prominent part of the life for Wallisians and Futunans.

"We come across fewer and fewer people who have never left Wallis and Futuna" (participant 3)7.

However, in the recent years, Wallis and Futuna has been experiencing a growing mass exodus of population and has been alarming to many of the participants.
“The perspectives for Futuna are very worrying. We are seeing an exodus of the population. There will be a time where there won't be any Futunans on Futuna" 8 (participant 9).

According to participant 10, today, the drive to migrate is caused by two main factors: to pursue higher education and to escape of socioeconomic factors. Additionally, many participants in Wallis and Futuna highlighted how difficult it was for a young graduate wanting to return due to political, economic and cultural factors.

\footnotetext{
7 « On trouve de moins en moins de gens qui sont pas partis de Wallis et Futuna » (participant 3).

8 « Les perspectives pour Futuna sont très inquiétantes. On voit un exode de la population. Il y aura un moment où il y aura plus de futuniens sur Futuna » (participant 9).
} 
"We block their endeavours bureaucratically, socially, customarily, politically, economically" 9 (participant 44 ).

The following chapter will document the views of the local and expatriate populations in an effort to address the research questions:

* What are the initiatives to support education and training of Wallisians and Futunans and are they successful?

What opportunities are there upon the return of students/graduates?

* Are there limiting factors for the return of students and possible economic activity in the territory?

The chapter is structured to mirror the path of a young person from high school, to higher education or training, to employment and will identify the challenges that they may encounter along the way.

\section{2 "We need qualifications here"}

\subsubsection{Transfer of system}

Participants have argued that access to French education is a form of introduction to the West (participant 3 ) and is a form of entrance of Wallisians and Futunans into the French principals of egalité, liberté and fraternité (equality, liberty, fraternity) (participant 12) and helped form Wallisians' and Futunans' rich identity (participant 3).

"Education started in 1961 but when you gain a foothold in education, you're going into democracy. In the French system, it's the French way of thinking, the Western way,

\footnotetext{
$9_{«}$ On leur bloque la route administrativement, socialement, coutumièrement, politiquement, économiquement» (participant 44).
} 
and the European way. It is what makes us what we are today. We are (culturally) wealthy" ${ }^{10}$ (participant 3).

Additionally, education is crucial in Wallis and Futuna to access employment as the same rules apply as in France (participants 32, 20, 5) and employment is allocated based on interviews and exams known as the 'concours', a competitive selection process, particularly within in the public sector.

"In the French system, the notion of skill is not the most important. Once we are qualified, we are seen as having the skills"11 (participant 32).

"In France, you have to have hairdressing qualifications to own a hairdressers"12 (participant 20).

As a result, many participants see higher education as a possible way to include more of the local workforce in employment because currently, a significant number of jobs are occupied by metropolitan (participant 7,45 ).

"We need qualifications here, especially to occupy the metropolitan positions. To be a professor, a head teacher, a head of department, they require a diploma. Which are many years of study"13 (participant 45).

The French educational system has been designed to offer equal opportunities for students but also to create a system that can support productive members of

\footnotetext{
${ }^{10}$ « La scolarisation a commencé en 61 mais quand vous mettez un pied dans la scolarisation, vous rentrez dans la démocratie. Dans le système français, c'est la pensée française, occidentale, européenne. C'est tout ça qui fait ce qu'on est aujourd'hui. On a une richesse » (participant 3).

${ }^{11}$ « En France, une fois qu'on est diplômés on est considéré comme ayant la compétence de...» (participant 32).

12 «En France, t'es obligé d'avoir le diplôme coiffeur pour avoir un salon de coiffure » (participant 20).

${ }^{13}$ « Il faut des diplômes ici, surtout pour occuper les postes des papalagis. Comme professeur, principal, ou chef de service, ils exigent des diplômes. C'est beaucoup d'années d'études» (participant 45).
} 
society (participant 32 ). As Figure 5 below demonstrates, the French educational system is intended to be coherent in order to train a well-rounded individual that is also an expert in their field (participant 32).

High schools offer many different subjects and paths, including practical-based subjects and theory-based subjects such as Economics or Literature to provide the students with a head start in their careers or higher education paths. In higher education, students are provided with another array of choices, which are determined by the students' high school subjects (participant 32). These choices also determine the institutions or universities the student would be able to apply for. As the table demonstrates, a student that has chosen the 'professional path' at high school is likely to remain in that path. 


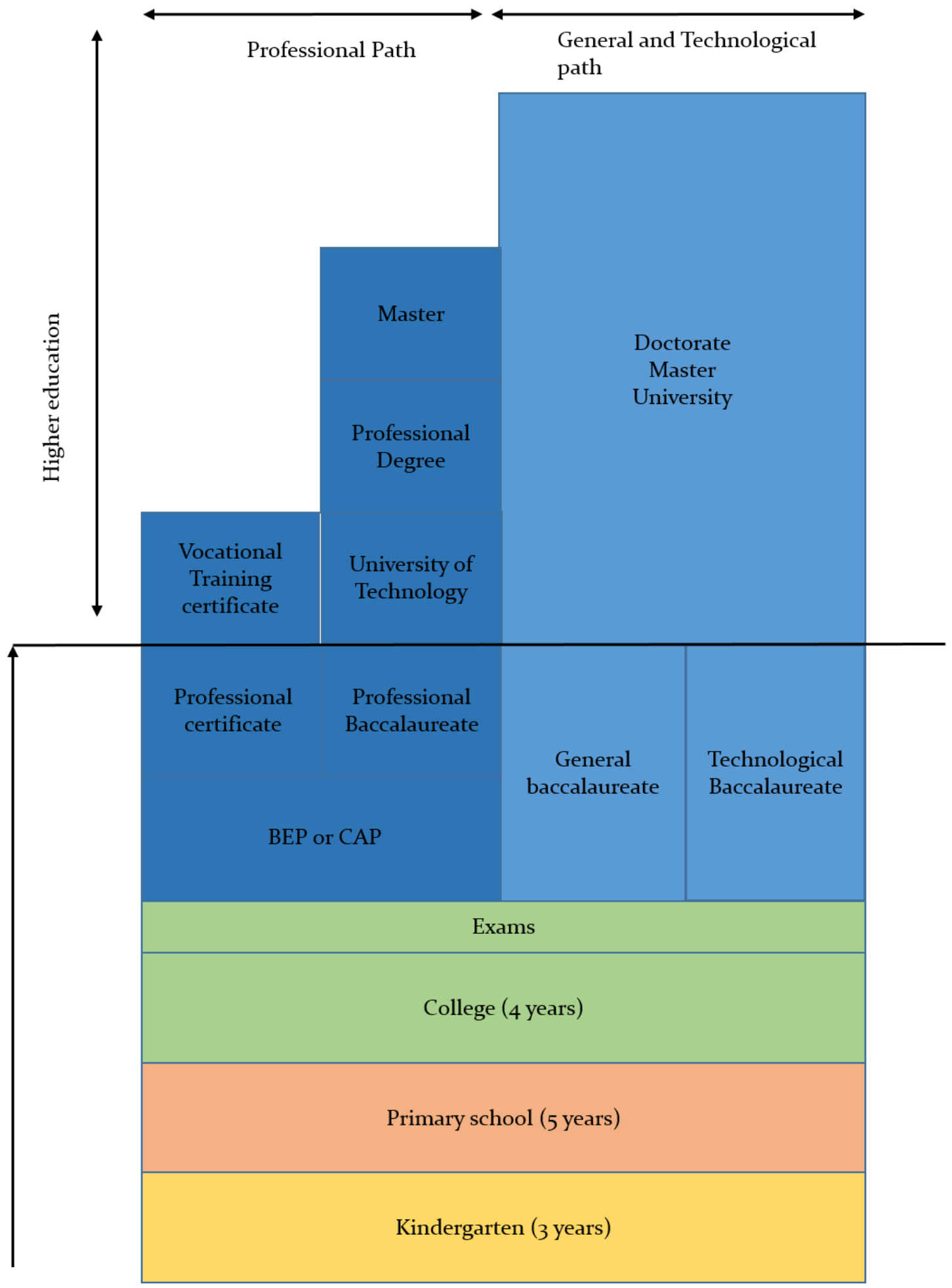

Figure 5 The French educational system. Adapted from ONISEP (2016) 
This system has arguably provided the territory with the opportunity to increase human capital. However, in the context of Wallis and Futuna, this system can be problematic. As a set structure, it is extremely difficult to change or adapt the system according to local situations (participant 32).

\begin{abstract}
"There are a certain number of criteria that are important for this system to work well, which means that if you introduce adaptations, this system will struggle. Either we take the system in full in the way that it is supposed to function and in this case, it has effects that are in a way positive, or we introduce adaptations that make it malfunction completely" ${ }^{14}$ (participant 32 ).
\end{abstract}

And according to participants (participants 11, 23, 24, 25, 26, 27, 18, 42, 49), teaching methods and material are not adapted to the territory and sometimes contradicts traditional education. Moreover, the system has had an important impact on the students' opportunities for the future in the territory or abroad as it has a crucial influence on what they study, where they go and whether they succeed.

\title{
4.2.2 High school
}

As set by the structure, high school is a starting point for the students' journey in education and for their future career. In Wallis and Futuna, high school could determine the students' success but could also improve their possibilities to return to the territory.

\footnotetext{
14 « Il y a un certain nombre de critères qui sont important pour que ce système fonctionne bien. Ça veut dire si tu introduits des adaptations, ce système a du mal. Soit ils prennent le système pleinement comme il doit fonctionner et à ce moment-là ils font des effets qui sont soi-disant positif, soit on y met des adaptations qui les font dérailler totalement » (participant 32).
} 
Interviews demonstrated the territory's intent to use education at high school to influence return to the territory and particularly to promote employment and economic activity. The local education authority (vice-rectorat) frequently organises meetings to discuss the current subjects at high school and establish potential new subjects that coincide with employment gaps in the territory. However, whether targeting subjects at high school is an effective strategy is debated amongst participants.

According to some participants, it is important to train young people regardless of whether they can find employment in this field at home because at least it would provide them with the opportunity to find employment overseas (participants 16, 28, 29, 30, 6o, 2) since there are few jobs available in Wallis and Futuna (participants 16, 44). Participant 16 thought that rather than providing subject that the territory needs, they should provide subjects that the students are interested in and according to their strengths. If the students are not put in the subjects of their choosing just to satisfy 'the needs of the territory', students will be set up to fail (participant 16).
"The objective is not that they return, it's that they succeed" 15 (participant 16).

To assign students into subjects that would help them succeed may be limited due to class capacity limits (participants 16, 44). At high school, priority is given to students with higher marks and other students are assigned to their subsequent choices when classes reach capacity. The professional subjects are often the most popular according to participants 15 and 16 and agricultural subjects are the least popular. Participant 44 said that students attending the agricultural high school are often assigned there because their other classes of choice were full. Participant 50 said he found himself studying agriculture because his marks were not high enough to join other classes.

\footnotetext{
15 « L'objectif, c'est pas qu'ils reviennent, c'est qu'ils réussissent » (participant 16).
} 
"Young people that study agriculture don't do it because they want to but do it because they have to but also so they can stay in the territory" ${ }^{16}$ (participant 44 ).

According to participant 44, there are opportunities for students to go to New Caledonia or France for secondary school and study subjects that are not offered at home but for financial and political reasons, the territory endeavours to fill the classes before students are able to request study overseas.

As a result, participants argued that this system could impact the students' success, since not all students will be able to study subjects of their choice. Participant 16 believed that of those who don't succeed, very few return. Nevertheless, participant 2 stated that the territory could select the best students and train them according to what is required in the territory, whilst providing the opportunity to others to succeed even if it is outside of Wallis and Futuna.
"We could do it and favour the subject choices based on the needs of the territory and after, for the others, enable people to have a life outside if they can't have a job here"17 (participant 2).

However, it has been argued that the complexity of the system causes confusion amongst students who choose their subjects based on their interests, rather than their future career (participant 32). Due to the structure explained in 4.2.1, students could be locked into a path and end up in a profession contrary to their ambitions and could impact the students' possibility to return even if it was their intention from the start (participant 32). For this reason, many have argued that it is important that the students understand the system and that they are aware of what is lacking in the territory to make an informed decision on their future

\footnotetext{
${ }^{16}$ « Les jeunes qui font des formations agricole ne la font pas par motivation mais la font plus par obligation de scolarité et aussi pour rester sur le territoire» (participant 44).

17 « On pourrait le faire et favoriser des orientations pour les besoins propres du territoire et après pour le reste permettre aux gens d'avoir une vie ailleurs si ils ne peuvent pas avoir du travail ici» (participant 2).
} 
studies (participants 2, 42). Yet, participants doubted the feasibility of this since there had been no official report outlining the employment gaps (participants 13, 16, 43). Participants emphasised that when they were choosing their subjects, they were not told what was required on the territory (participants $55,56,57$ ).

Participant 42 explained that it is difficult for students to choose subjects based on the future if they are unaware of the possibilities.

"I think that there is isn't enough preparation when it comes to choosing the subjects for students are high school because they haven't left Wallis and Futuna. (...) There are a lot of jobs that they could do here and create for Wallis and Futuna but they aren't aware of it. There should be a study on the possible jobs that could be created here and direct young people in those fields" ${ }^{18}$ (participant 42).

Due to the rigidity of the system and a lack of information on the needs of the territory, participant 42 believed that many do not really know where they are heading and if "they don't see the end goal, they don't continue"19 .

Another important criticism to the system is that there is no follow-up for the alumni (participant 58). The territory is unaware of the students' achievements. Participant 16 thought that without a follow-up system, there is no point in considering what subjects to provide at high school.

\footnotetext{
${ }^{18}$ « Je trouve qu'il n'y a pas assez de préparation au niveau de l'orientation des jeunes, des lycéens, parce qu'ils sont pas sorti de Wallis ou de Futuna. Il y a beaucoup de métier qu'ils pourraient faire ici - créer pour Wallis et Futuna mais ils sont pas au courant. Il faudrait qu'il y ai une étude sur les métiers à pourvoir sur Wallis et Futuna qui pourraient être créer et orienter les jeunes dans ses branches là » (participant 42)

19 «Si ils voient pas d'objectif, ils continuent pas » (participant 42).
} 
"We introduce new courses without really knowing what young people want and without knowing where these young people end up" 20 (participant 16).

In fact, interviews with the students revealed they did not know why they were leaving but knew that they had to. Many were going abroad to pursue their studies because it is what was expected (participants 23, 24, 25, 26, 27). Many student participants chose a path that they thought provided them with better opportunities for return and were particularly in line with existing professions in the territory (participants 23, 24, 27, 45, 52). For instance, participant 27 wanted to come back to Wallis and Futuna to teach.

“For me, leaving is an obligation. If we stay here, we can't find work easily because quite simply, there is no work. To further my studies, I need to go to New Caledonia or France because I want to become a teacher in electronic engineering"21 (participant 27).

It was evident that many knew that they had to leave because there are very few jobs available for young people with high school diplomas (participants 54, 55, 56).

"After when we finished high school, because there aren't a lot of jobs here, we needed to leave" ${ }^{22}$ (participant 55).

\footnotetext{
${ }^{20}$ « On met en place (...) des nouvelles filières mais sans savoir vraiment ce que les jeunes veulent et sans savoir ou est-ce que les jeunes atterrissent en fin de compte » (participant 16).

${ }^{21}$ « Pour moi partir est une obligation, si on reste ici on ne peut trouver facilement du travail car tout simplement, il n'y a pas de travail. Pour poursuivre mes études je dois partir en Nouvelle Calédonie ou en France parce que je voudrais plus tard devenir professeur en électrotechnique » (participant 27).

22 "Après quand on a eu notre bac, comme il y a pas trop de débouchés ici, on devait partir" (participant 55).
} 
In a way, the design of the French educational system may be an asset for Wallis and Futuna to maintain a handle on students' paths and direct an active return but difficulties in the territory can impact these possibilities.

These issues have been identified by the populations and a few participants have provided support to aspiring university students (participant 58, 32, 33, 28).

\subsubsection{Degree choice and destination}

Interviews showed that students encounter additional difficulties in their destinations.
“They are confronted to difficulties that they are not used
to that aren't necessarily to do with schooling but
difficulties pertaining to everyday life”23 (participant 28).

Participants stated that they left Wallis and Futuna with little information on what to expect when they arrived at their destination (participant 53,43, 58). Students also encountered other issues pertaining to the level of French for instance (as people speak their vernacular language at home), adapting to working on their own and researching (as education in Wallis and Futuna is more of a communal experience), adapting to having to pay taxes, getting used to the paperwork, the climate (participant 45, 22, 42).

Students also face high registration fees and high taxes that they cannot always afford. For some participants, the territorial grant was not available to them for four months and many had to find other ways to support their studies (participants 43, 45). Participant 43 needed to have a part time job in order to cover the costs of her studies, working weekends and nights. This extra work eventually impacted on her studies as she had to skip classes. Participant 59 also

\footnotetext{
23 «Ils sont confrontés à des difficultés qu'ils ont pas habitudes de faire face qui sont pas forcément scolaire mais des difficultés par rapport à la vie de tous les jours » (participant 28).
} 
stated that some students are led to illegal lucrative work because they cannot afford the fees.

Participants have stated that since there have been few problems with the territorial grant but these grants do not cover all expenses (participant 45). Furthermore, for those without access to a grant also struggle financially. Many rely on financial support from family members (participant 53 ).

However, in some situations, families may not be able support students due to customary and religious pressures (participant 17). Participant 17 argued that many families invest their money in traditions and the church, rather than saving to support their children in their studies. Students in these cases are then only accompanied by the 'institution' (participant 17).

"For me the biggest worry is that we live in the present, there is no anticipation for children. We aren't going to calculate so that our children can go to university. (...) We spend, we spend, we spend" 24 (participant 17).

"The norm would be- I go to the church, I give to the church and the lord with give back - it will be given back to my children" 25 (participant 17).

For students moving away from their families and abroad for the first time, the first year is where they discover and adapt and many have to repeat as a result (participants 17, 3, 60, 29, 37). Some young students drop out of university after one trimester, a year and sometimes find a job and or join the army because they struggle with the change or with financial pressures (participants $28,44,60,11$, $53,45)$.

\footnotetext{
24 « Enfaite, moi les soucis c'est qu'on est dans le présent, il y a pas d'anticipation pour les enfants. C'est-à-dire qu'on ne va pas calculer à ce que les enfants aillent à l'université. Enfaite, c'est la gestion Wallisienne de la monnaie et totale absence d'anticipation. On claque et on claque et on claque » (participant 17).

25 « Les mœurs ça va être - je vais à l'église, je donne à l'église et le seigneur va rendre. - ça va être rendu à mes enfants » (participant 17).
} 
"Often, young people in France fail in their studies and end their education to go into the private sector to find work or to join the army and then do not return" ${ }^{26}$ (participant $44)$.

"We've found that students that leave with their parents have a little bit more chance to succeed" 27 (participant 28).

However, not many can't afford to accompany their children due to the expensive airfares (participant 28).

To help ease integration process and lighten the financial strain, having host families abroad is important. The most common destinations are New Caledonia, Metropolitan France and French Polynesia because of the established networks and the ease of accessibility for French citizens.

As a result, some students highlighted that they had to choose their courses/studies depending on the location of their networks (participant 2, 28, 29, 30, 52). Their study options were constrained to the options provided by the institutions in the local area of their destination. For instance, participant 52 was a young high school graduate waiting to move to Paris to join her sister. She was unable to find a course that she wanted to study within institutions around Paris and had to choose another course. The initial course that she wanted would have provided her with the skills to possibly return and find employment but the one that she has enrolled in may not provide such opportunities.

In addition, many participants expressed preference to remain within the Pacific, because of the physical distance and cultural proximity, which prove important

\footnotetext{
${ }^{26}$ « Souvent de fois, les jeunes en France se trouvent plus ou moins dans une situation d'échec et mettent un terme à leur formation pour s'orienter dans le domaine privé ou ils se mettent à travailler, à trouver des emplois, à s'engager dans l'armée et ne reviennent pas $»$ (participant 44).

${ }_{27}^{2}$ « On a constaté que les élèves qui partent avec les parents ont quand même un peu plus de chance de réussir » (participant 28)
} 
for the students' ease of integration (participant 42). However, for some students the possibility to move to the Pacific is limited. For instance, study options and available places are relatively restricted in New Caledonia and French Polynesia and many are still forced to go to Metropolitan France as a result (participants 22, 34, 35). This is particularly the case in New Caledonia as locals are given priority for places in high schools and perhaps even universities (participants 14, 15). Furthermore, the limited established networks in French Polynesia deter students from studying there (participants 12, 48).

Migration for education to New Caledonia has been a concern for both New Caledonia and Wallis and Futuna because few students have returned to the territory. According to participants 7 and 16, the accord particulier (2003), as discussed in section 1.4.3, aimed to tackle this rapid outmigration. New Caledonia endeavoured to support certain sectors of education on the island to inspire return to the territory. The Université de la Nouvelle Caledonie installed a branch called Institut Universitaire de Formation des Maîtres (IUFM) in MataUtu to provide training for aspiring primary school teachers locally. However, this branch drastically increased the number of qualified teachers and due to the population decline, Wallis and Futuna had more teachers than was required (participant 10) and IUFM has since been closed. New plans intend to convert the premises into a research facility to welcome researchers from overseas (participant 7). Unfortunately, this will not assist in controlling outmigration other than providing a few jobs on the premises (participant 10).

Additionally, few students pursue studies outside of France since they are not covered by the territorial or state grants (participant 2). Although there are grants from New Zealand and Australia available, the numbers of Wallisian and Futunan students in New Zealand and Australia remain very low (participants 1, 59). Participant 59 stated that degrees may not be recognised upon return as it is still very difficult to transfer students' qualifications from New Zealand and Australia. In addition, language has also been a barrier to education in neighbouring countries and has in a way limited the territory's relationship with the region (participant 2). 


\subsubsection{Other opportunities for education}

Another option for young people in Wallis and Futuna for education or professional training is through the programmes offered by the Service de l'Inspection du Travail et des Affaires Sociales (SITAS). The SITAS has two main programmes, one sends young students in training overseas and another sends educated workers for professional training for a particular job in the territory ( 40 Cadres).

The 40 cadres programme provides people with the required training and qualifications to enter targeted higher-level positions upon their return to the territory. With this initiative, vacant professional positions are identified or created for the trainee.

Many participants, particularly in the public sector, benefitted from the programme. For instance, participant 12 was able to enter a position through this training opportunity in the civil service. ${ }^{28}$ It is also an opportunity for those who can afford their studies to ask to be sponsored. Participant 22 is a student waiting to leave for her studies but because she isn't eligible for a study grant, she has asked the SITAS to financially support her in her studies. Participant 19 applied for the 40 Cadres because he wanted to further his studies but couldn't afford the fees. With the 40 Cadres he was given a contract of five years to develop an activity in the territory when he returned, which he did.

However, according to participants, SITAS predominantly offers training programmes abroad for people wanting to go into the public sector. Participant 42 thought that they are training people in sector that has reached capacity and therefore will not be employed upon return.

\footnotetext{
${ }^{28}$ « Au bout de la formation ils ont un travail. Une Wallisienne est partie en formation avec le SITAS, elle a fini sa formation, elle a occupé des petits boulot, elle a fait surveillante dans les établissements ensuite elle a passé un concours et là elle travaille au service de la gendarmerie. Maintenant, elle reste là-bas, elle a un travail. Elle aide financièrement ses parent » (participant 45).
} 
"I tried to ask the SITAS if they could, because they offer training, if there was a possibility for them to fund my teaching training but they refused. They said that it wasn't possible because the SITAS sends young people in training in the civil service, secretarial studies and accounting" 29 (participant 42).

According to participants, many still do not return with this programme and the programme no longer covers all the costs as a result (participants 42, 12).

In addition, one of the most common alternative pathways that many young Wallisians and Futunans choose is to enlist in the army. According to participant 18, the army provides an alternative option and an opportunity for success to the more 'difficult' students. This initiative has helped young people whose prospects were limited in the territory either because of their level of study or their financial situation (participant 18). The army is often attractive to students who struggled at school (participant 42).

Participant 18 argues that this initiative provides opportunities to either succeed abroad or in the territory upon their return and sees this pathway as potentially providing the tools to young people to return, develop and to create their own businesses.

The army offers to pay for training for different skills and these qualifications are also transferrable if applying for jobs after they leave the army.

\footnotetext{
29 «J'ai essayé de demander au SITAS si ils pouvaient, comme ils offrent des formations, si il y avait des possibilités de financer des formations pour l'enseignement et ils ont refusés. Ils ont dit que c'était pas possible parce que les SITAS envoient des jeunes en formation plus dans l'administration, secrétariat, comptabilité » (participant 42).
} 
"It offers many possibilities. (...) It is the easiest job to access. After you can be a soldier, mechanic, cook, accountant etc"30 (participant 45).

Furthermore, people in the army receive a monthly salary, which they can remit to family members (participant 18 ).

Participant 45 thought that the army is also a common alternative pathway for those struggling financially at university. Generally, people sign up to a contract of five years and at the end of the five years the person has a choice to sign up again or ask to be transferred (participant 45). Participant 45's husband was in the army for eleven years and needs to stay for at least nineteen years to make sure he has a pension. For this reason, many of the returnees are retired officers (participant 45, 18). Although it provided participant 45's husband with opportunities, he would have preferred to continue his studies if he was financially secure. Additionally, participant 42 noted that the army has become even more popular amongst young people since the SITAS no longer covers all the costs.

Other options include training programmes in Fiji (participant 43) or language courses in New Zealand or Australia but these are still few.

Participants stated that young people use the army, the SITAS and higher education in general as a way to leave the territory (participant 33, 9, 29, 17).

"The easy solution is to leave with the army" ${ }^{11}$ (participant 17).

\footnotetext{
$3^{0}$ « Ca offre beaucoup de possibilités... C'est le métier le plus facile d'accès. Après tu peux être combattant, mécanicien, cuisinier, comptable...» (participant 45).

${ }^{31}$ « La solution de facilité c'est de partir à l'armée » (participant 17).
} 
"I think they are programmes that influence people to leave. They're not programmes to incite the population to find solutions to stay in the territory" ${ }^{22}$ (participant 29).

"There are other young people who want to continue (high school) just so they can leave and study and after they stop. It's the bursaries that allow them to leave"33 (participant $60)$.
"Some have criticised the SITAS saying that it is a tourist agency, that they send young people just for them to go to France but there is now follow up for their training" 34 (participant 42).

Furthermore, according to participant 13, there is an important link between the training offered and the development strategy of the territory but because this is lacking in direction, the territory cannot fully benefit from this training. Participant 29 similarly believed the trainings or subjects offered depend on the political agenda.

\footnotetext{
$3^{2}$ « Je pense que ce sont des dispositifs qui incitent la population à partir. C'est pas des dispositifs pour inciter la population de trouver des solutions pour y rester sur le territoire parce que le service militaire, forcément il y a pas de bases militaires ici donc les jeunes sont forcés de partir ailleurs. Pareil pour la formation 40 cadres, une fois que le Wallisiens et le futuniens diplômés après sa formation, soit il a de l'emplois ici à Wallis, ou bien il est obligé de rester ailleurs pour trouver de l'emploi » (participant 29).
}

33 « D’autres jeunes qui veulent continuer juste pour partir faire des études puis ils arrêtent. C'est les bourses qui leurs permettent de partir » (participant 6o).

34 « Il y en a qui ont critiqué le SITAS en disant que c'est une agence touristique, ils envoient les jeunes juste pour partir en France mais il y a pas de suite pour leur formation »(participant 42). 
"Everything depends on the political direction because they can't offer the maximum, an array of jobs, for the different fields of activity"35 (participant 29).

Participant also believed that that to guide students' studies to increase possibilities for return is trivial when there are limited opportunities to use this skill in the territory.

"We send our young people to be trained but they forget that they need qualifications in order to be employed and to be employed in the territory, there needs to be a position" ${ }^{6}$ (participant 7 ).

\section{3 "There are no jobs"}

In fact, one of the main reasons for a lack of return appears to be the lack of employment available in the territory. Participants pursue higher education because it is the main gateway to waged employment attributed to changing aspirations in society.

"What interests the generations now are the salaries, money" 37 (participant 50).

Though, qualified graduates are left discouraged when they return and there is no employment available.

“They (the parents as well) push us to continue our studies and to do this and do that but after, when we come back

\footnotetext{
35 « Il y a beaucoup de facteurs qui sont liés à tout ça parce que c'est politique. Tout dépend des orientations politique du territoire parce qu'il ne peut pas offrir un maximum, une panoplie d'emplois pour les différents secteurs d'activité » (participant 29).

${ }^{36}$ « On envoie les jeunes pour être formés mais ils oublient qu'il faut les qualifications pour être embauchés et pour être embauchés sur place, il faut avoir un poste » (participant 7).

37 « Ce qui intéresse les générations maintenant, c'est les salaires, les sous » (participant $50)$.
} 
and ask for a job, they tell you 'we don't have anything for you'. It gives us false hope" $3^{8}$ (participant 45).

Although many young people who leave the territory, leave with the intention to settle permanently, many want to return and find employment (participants 1 , $12,38)$.

"People who I studied with and who now work in New Caledonia, they are on the internet every day, looking to see if there is an opportunity that might open up here" 39 (participant 38).

\subsubsection{Public Sector}

As highlighted in section 1.4.2, the public sector is the highest provider of jobs in the territory. Jobs within this sector are in high demand, as the salaries can be significantly high compared to less secure private sector employment. According to participant 44 , a recent strike saw the starting wage within the administration rise to 150 ooo. It is additionally very highly regarded to be employed in this sector.

Many participants agreed that because of the limited places available at the Territorial Assembly and Administration, young people will have to wait until someone retires since people rarely vacate these jobs (participant 7, participant 1). Young people looking to be employed in the bureaucratic sector will have to wait "for someone to die or resign" 40 (participant 45 ).

\footnotetext{
$3^{8}$ «On (les parents aussi) nous pousse à aller continuer les études et à faire ceci et faire cela mais après quand on arrive on demande à entrer mais on te dit, on a rien à t'offrir. Ça donne un faux espoir » (participant 45).

39 « Les jeunes qui étaient avec moi et qui aujourd'hui travaillent en Nouvelle Calédonie, tous les jours ils sont sur internet à guetter pour voir si y a pas un emploi qui va se libérer ici » (participant 38).
}

40 “que quelqu'un part ou meure ou démissionne » (participant 45). 
“In the civil service, it's only when they retire. They won't take young people like that. They don't want to create positions" ${ }^{41}$ (participant 43 ).

However, the weight on the public sector is limiting the opportunity of those who return to find a job because it has reached capacity.

"We can't create, create, create positions"42 (participant 7).

Furthermore, these jobs are becoming more scares as the bureaucracy is shrinking due to the decreasing population and some positions are not being renewed (participants 38,10 ).

"I have had some people leave for retirement who weren't replaced because that position is no longer required due to the demographic decrease" 43 (participant 10).

"I think that even fifteen years ago, those who succeeded had one ambition which was to become civil servants well to stay in the territory. The problem is that in that case, they have taken these places and now we need to wait for them to be of retirement age. The population is in the process of crumbling, the departments aren't going to increase positions, on the contrary" 44 (participant 6).

\footnotetext{
${ }^{41}$ «A l'administration, c'est seulement quand t'as des retraités. Ils ne vont pas prendre comme ça des jeunes. Ils ne veulent pas créer des postes » (participant 43).

42 « On ne peut pas créer, créer, créer des postes » (participant 7).

43 « J'ai eu des départ en retraite qui n'ont pas été remplacés parce qu'il n’y en a plus besoin du à la baisse démographique » (participant 10).

44 « Je pense que y’a même quinze ans, ceux qui réussissaient avaient ambition de devenir fonctionnaire, 'fin de rester sur le territoire. Le problème c'est que du coup ils ont pris les places et maintenant il faut attendre qu'ils soient à l'âge de la retraite. La population est entrain de s'éffondrer, les services vont pas augmenter, au contraire » (participant 6).
} 
"In this sense, it's kind of a vicious cycle. Everything goes out of control. More the island becomes empty, there are fewer reasons to have civil servants, there are then fewer reasons to have important subsidies. Then there are fewer subsidies and fewer jobs. If there are fewer jobs, there is more of a need to leave" 45 (participant 22).

It appears that access to education has had a positive impact on the local populations as the territory experiences a slow 'turnover' where more locals are occupying positions in the public sector, a sector previously dominated by metropolitan (participant 14 and 15, participant 45). For this reason, many locals are choosing to enter professions such as teaching (participants $45,34,35,27$ ). Although many teachers are still currently from the metropolis (participant 45), many prospective students and returning students were going to or had pursued their studies with teaching in Wallis and Futuna in mind.

"Everyone wants to go into teaching because you're sure that they're going to give you a job. You put a lot of effort into it and you know that they're going to give you a job in Wallis and Futuna"46 (participant 45).

However, participant 7 highlighted that during the application process, Wallisians and Futunans are not always prioritised for positions in the territory if they are national civil servants.

"The state is a circuit. There are teachers and these teachers are older, they have earned points. When you, a

\footnotetext{
45 « Du coup c'est un cercle un peu vicieux. La machine s'emballe. Plus l'ile se vide, moins il y a de raison d'avoir des fonctionnaires, moins il y a de raison d'avoir des subventions importantes qui arrivent, donc moins il y a des subventions, moins il y a de l'emploi, moins il y a de travail, plus il faut partir » (participant 22).

${ }^{6} 6$ «Tout le monde veut aller dans l'enseignement parce que t'es sûr qu'on va te donner un poste. Tu t'investis entièrement et tu sais qu'on va te donner un poste sur Wallis et Futuna» (participant 45).
} 
young Wallisian, you have your CAPES47, you come back to Wallis, you would like to teach maths- Ok, you enter the national movement and in these movement, they think it's a young person, we'll put them in Martinique for example"48 (participant 7).

This 'national movement' puts teachers in a national pool. A teacher is transferred to schools based on qualifications, regardless of origin. In this case, teachers from Wallis and Futuna, if they find themselves in national employment will not necessarily be sent home to work. However, participant 45 argued that if there were too many teachers in Wallis and Futuna once the turnover is complete, this system might work to the advantage of Wallisian and Futunan teachers, as they would then be able to be transferred within the French territories.

In contrast, there is concern for primary school teachers as the requirements for teaching in Wallis and Futuna are different to the qualifications required in France or New Caledonia. For that reason, these teachers will not be qualified to teach anywhere else (participant 21).

In other specialised sectors for instance, the public sector continues to be dependent on foreign workers when there are no Wallisians and Futunans qualified for the positions. There are opportunities available for niche, specialised personnel.

"We would need brainpower in a lot of sectors. Every studies that we do and the work that we carry out is done by people from outside that we need to bring over for eight

\footnotetext{
47 The CAPES is a teaching qualification

${ }^{8}$ « L'Etat c'est un circuit. Il y a des professeurs et ses professeurs sont anciens, ils ont des notes. Quand toi jeune Wallisien, t'as ton CAPES, tu viens à Wallis, t'aimerai enseigner les maths - d'accord, tu rentres dans le mouvement national et dans ses mouvement nationaux, ils se disent c'est un jeune, on va le mettre en Martinique par exemple » (participant 7).
} 
or fifteen days to conduct our studies because we are unable to conduct them locally" 49 (participant 44).

According to participants, the lack of follow-up of local graduates may be preventing the territory from using local experts. Unless the graduates return to the territory and apply to positions themselves, the territory will be unaware of the human capital available abroad.

"The problem is that we have never had a census of all the graduates outside of the territory but I think that we have quite a few graduates that have qualifications at a very very high level" $5^{\circ}$ (participant 28).

There are other opportunities in the civil service that, according to participant 9, have allowed more young people to find employment. For instance, participant 9 works with many young engineers in the civil service on Mata-Utu.

This weight on the public sector is impacting the economy of the territory and people are looking for solutions to develop the private sector as will be discussed in the next section.

"A public system will not be able to sustain the economy in the territory" ${ }^{11}$ (participant 13).

\footnotetext{
49 « On aurait besoin de matière grise dans pas mal de domaine. Toutes les études que l'on fait ou les travaux que l'on mène c'est fait par des gens de l'extérieur qu'on est obligé de demander de venir sous forme de mission de huit jours a quinze jours pour nous faire des études parce qu'on est pas capable de les faire localement » (participant 44).

$5^{\circ}$ « Le problème c'est qu'on a jamais fait de recensement de tous les diplômés hors territoire mais je pense qu'on a pas mal de diplômés à des études supérieures très très élevés» (participant 28).

${ }^{51}$ « Un système public ne pourra pas soutenir l'économie du territoire » (participant 13).
} 


\subsubsection{Private sector and creation upon return}

Although there is relatively high return of skill to the territory, participant 9 states that it is skill they cannot use.

"But this (education) skill collides with an economy that is practically non-existent. There is a large portion of the young population that do not return because they have acquired knowledge that could be recognised and utilised within a business" 52 (participant 9).

Participants highlighted that there was an important need to create activity in the territory and opportunities to develop the economy are arguably ample but the tools to do so are absent. As many participants have emphasised, to develop the economy is quite an impossible task given the system in place acting as a barrier (participant 7 ).

"Everything is against the development in Wallis and Futuna really"53 (participant 46).

When the graduates return, they are left to fend for themselves 54 (participant 18). Many have noted that the students are only provided with the tools for education and very little tools to help them use the skills (participant 9).

\footnotetext{
$5^{2}$ « Mais qui se heurte aujourd'hui sur une économie qui est quasiment inexistante. On a une grosse partie de la jeunesse qui ne reviennent pas qui ont acquis un savoir-faire qui pourrait être valorise dans une entreprise » (participant 9).

53 « Tout est contre le développement sur Wallis et Futuna quoi » (participant 46).

54 «Il faut se débrouiller » (participant 18).
} 
“They don't help us with the infrastructure that is completely rotten. We can't go ahead on our own with their way of doing it at the moment" 55 (participant 46).

The possibilities for activities in the territory are debated amongst participants. Some have argued that there could be opportunities in many sectors but these are always subjected to debilitating factors such as the many monopolies, the lack of interaction with the region and the limited access to the global market for export.

"We're on a small island with very few resources so to develop activities here, apart from the primary sector such as fishing, agriculture where there may be some things to do, in the secondary and tertiary sector it's limited" 56 (participant 44).

Others have argued that the money is not invested in the right places. Participant 42 thought that money is pumped into religion and custom or for personal gain when it could be used to fix infrastructure or used in ways to develop activities on Futuna.
"They need to put forward training in handicrafts, carpentry because we have the wood needed instead of building churches for nothing (...)” 57 (participant 42).

In addition, the system in Wallis and Futuna has particularities that are not taken into account in laws and legislation to help businesses locally. For instance, any

\footnotetext{
55 « Et en plus eux ils nous aident pas avec les infrastructures qui sont complètement pourris. On ne peut pas se lancer individuellement quoi avec leur façon de faire actuellement » (participant 46).

${ }^{56}$ « On est une petite île avec très peu de ressources donc aller développer les activités ici, mis appart dans les milieux primaire, la pêche, l'agriculture ou il pourrait avoir des choses à faire, dans le domaine secondaire et tertiaire c'est limité »(participant 44).

57 « Il faut valoriser des formations dans l'artisanat, menuiserie parce qu'on a le boit qu'il faut, au lieu de construire des églises pour rien. Ils font de grandes structures mais ils ne voient pas l'état de la route - c'est un grand soucis » (participant 42).
} 
potential exports could be by plane but flights are too expensive, and shipping boats are too infrequent (participant 7 ). Furthermore, similar products from the rest of the Pacific are cheaper due to the lower wages (participant 44).

A lack of financial assistance available is an important factor in the possibility for creation amongst young returnees, which is why returnees often look for employment opportunities in already established activities.

"The problem that is occurring all the time is that there
isn't really a territorial budget that helps create businesses.
That's why young people are more likely to work in
commercial businesses or in the civil service"58
(participant 43).

Furthermore, the loans remain extremely low and practically impossible to help someone in financial difficulty to start a business. ADIE is a microcredit loan organization, which provides new businesses with a small start-up loan. However, participants have argued that given the high start-up costs, these microcredit loans rarely cover the fees (participant 20, 46, 33). Thus, in order to create activity, returnees will often either have to have the funds, or need to borrow money from family members to provide a supplement or a guarantee against their initial loan from the bank or ADIE.

"There needs to be more subsidies supporting projects.

Every time we put in a request, it's 8000 euros, that's not a long-term project" 59 (participant 33).

Business developers would also be subjected to high import costs. Taxes on imported goods are extremely high and for someone looking to import

\footnotetext{
$5^{8}$ « Le problème qui se pose tout le temps c'est qu'il n'y a pas de budget territorial pour créer. C'est pour ça que les jeunes sont plus dans la vente, dans le commerce, dans l'administration » (participant 43).

59 « Il faut que derrière on ait des subventions. A chaque fois qu'on fait une demande c'est 8000 euros, c'est pas un projet à long-terme » (participant 33).
} 
machinery or necessarily goods required for the business would face high costs (participant 19).

"I wanted to go into the private sector but it's hard. The fact that they stop our enthusiasm in the territory. We're blocked by the taxes, it's not adapted. You're forced to pay taxes even if you don't have any activity or profit in the territory. When you create a business, even without any activity, you're forced to pay the territorial taxes. It's a bit stupid really" 6o (participant 46).

It is also evident that lower salaries in the private sector limit development in the territory.

"This is why the private sector struggles to keep people (workers), it's because it isn't appealing. There are many young people, when they return and start an activity, they always have an eye on a position that could be freed up at the civil service and then they go for it. After, they give up (their business) because they will be better paid, they will be worry-free"61 (participant 44).

In addition, due to customary land tenure it is very difficult to buy or rent property. People wanting to set-up business would have to use family land and property provided that it is approved. This is a severe disadvantage to those who do not have access to land. Often, those who want to start a business will use

\footnotetext{
6o « Je voulais me lancer dans le privé ici mais c'est dur. Le fait qu'on nous coupe l'élan sur le territoire. On est bloqué par la patente et les impots, ce n'est pas adapté. T'es obligé de payer la patente même si t’as pas d'activité ou de bénéfice sur le territoire. Quand tu créer une société quoi, même sans activité t'es obligé de payer la taxe de territoire. C'est un peu con quoi » (participant 46).

${ }^{61}$ « C'est pour ça que le privé a du mal à garder ses emplois parce que ce n'est pas attirant. Il y a beaucoup de jeunes, quand ils reviennent et qu'ils commencent une petite activité, il y a toujours un regard vers un poste qui va se libère à l'administration et puis ils se sautent dessus. Après on laisse tomber parce il sera mieux payé et il sera plus tranquille » (participant 44).
} 
their own land or 'rent' properties from family members (participants 42, 19). However, participant 44 thought that this isn't necessarily an issue for Futuna as people will always be able to find land available for them to use. The issue is that any activity on a family's land will be subject to the owner's conditions and agreements. So far, many activities have been halted as a result of disagreements with the owners of the land (participant 10) (see section 4.4.2).

The importance of custom and solidarity on the islands could also make it difficult for a returnee to gather profit, particularly in Futuna. According to many participants (participants 49, 45, 40,1,5,44,33), the business owners could be pressured to practice custom. This would result in accepting payments from family members in the form of a pig for instance or other offerings (participant 40). In addition, the revenue may be shared among the family members (participant 33). It could also be used to give to the church or go towards customary practices. Participant 40 on Futuna particularly struggled with this.

In addition, returnees are faced with a territory that has little need for a variety of businesses. The traditional culture is highly based on subsistence farming and swaps. For instance, participants argued that there would always be a family member that could do some plumbing, painting, fishing for free (participant 44).

"The fisherman, who are they going to sell their fish to? To people who themselves go fishing?” 62 (Participant 7).

For instance, participant 57 is a qualified architect but in Wallis and Futuna, there is no need for architects since villagers can design the buildings. The many churches built in Wallis and Futuna were done without the help of architects, it is a village task. Furthermore, a noticeable phenomenon in the territory is that people build houses progressively. A house may take a lifetime to build as they are constantly adding to the structure as soon as families can afford it (participant 1).

62 "Les pêcheurs qui existent, à qui ils vont vendre leurs poissons? A des gens qui eux aussi vont allez à la pêche?” (Participant 7). 
Another obstacle is the lack of consumer support in the territory due to the rapidly decreasing population.

“The trouble? We are only 12000 habitants. We don't have any consumers" ${ }_{3}$ (participant 7 ).

Participant 28 emphasised that the economy needs the private sector as consumers in order to support the economy. However, participant 19 highlighted that the private sector continues to import rather than supporting local activity.
"We need to protect local employment (activity) for example, if we produce wood and that the territory buys outside then we're going to stock that for nothing. A protection would be a quota, it would be for the man that taxes me too much and it would be to push people to buy locally" 64 (participant 19).

Furthermore, there is no regulation that protects local goods. Reliance on subsistence farming is becoming rarer and more people are relying on imported supermarket produce, including fresh produce. Local sellers have difficulty competing with the international market since imported goods can be less expensive than local products.

Because of the particularity of the territory and the barriers, graduates need to adapt what they learnt in relation to setting up a business.

"It's a real difficulty that young people encounter now when they return in the territory. They have projects, but

\footnotetext{
63 “L'handicap? On est simplement 12000 habitants. On n'a pas de consommateurs » (participant 7).

64 « Il faut protéger l'emploi local comme par exemple si nous on produit du bois et que le territoire achète à l'extérieur donc nous on va stocker là pour rien. Donc une des protections ce serait un quota, ce serait le mec qui me surtaxe pour pousser les gens à acheter local » (participant 19).
} 
they are confronted to another reality that is quite rare" ${ }_{5}$ (participant 9).

Despite these difficulties, a selection of returning graduates have demonstrated that adaptation and working around these barriers is a possibility. For instance, participant 42 and participant 19 developed their small businesses with limited resources.
“To prepare this activity, I prepared a year in advance to go see the customary authorities, to organise the lands, the farms. A year later, I started my business. Like everything else, there are barrier - we need to understand how it works" 66 (participant 19).

Furthermore, participant 19 thought that customary traditions aren't necessarily an obstacle for business owners as there are ways around it.
"But if we analyse thoroughly, I don't think it (custom) is an obstacle. Those who cultivate for instance, a farmer, they say they can't sell because of the custom that's stopping us. They can leave 50\% to sell for customary traditions and 50\% to commercialise" 67 (participant 19 ).

There is thus evidence that more young people want to return with the ambition to create. For instance, participant 22 wants to come back and create a business

\footnotetext{
${ }_{65}$ C'est une difficulté que rencontrent les jeunes aujourd'hui quand ils reviennent sur le territoire. Ils ont des projets mais ils sont confrontés à une réalité qui est assez rare » (participant 9).

66 « Pour faire cette activité, j’ai préparé un an à l'avance à aller voir les coutumes, les terrains, les exploitations. Au bout d'un an j'ai commencé mon activité. Comme toutes choses il y a des freins - il faut comprendre comment ça marche » (participant 19)

${ }_{7}{ }^{~}$ 《 Mais en analysant bien je pense pas que ce soit un frein (la coutume). Ceux qui cultivent par exemple, un éleveur, ils disent qu'ils ne peuvent pas vendre parce qu'il y a la coutume qui nous empêche. - ils peuvent laisser 50\% pour vendre à la coutume et $50 \%$ pour commercialiser » (participant 19).
} 
that farms prawns or fish to control the populations that are currently being overfished.

\section{4 "Everyone has their place"}

As previously explained, prior to 1961, Wallis and Futuna was a hierarchical customary monarchy. With the statute, the system has had to incorporate republican ideals and rights to work alongside the traditional ways. Until recently, education used to be reserved for the royal and customary families (aliki) of society (participants 1 and 21) but the gradual implementation of equal opportunity seems to have disrupted this system of hierarchy (participants 31, and 32 ).
"Being part of France mean being part of the 'block'. It's a republic and the republic is equal so everyone should be considered in the same way"68 (but in Wallis and Futuna), “everyone isn't equal to everyone" 69 (participant 32).
"(In the republic) everyone has the same rights, everyone has the right to succeed, which disrupts a bit everything that happened before" ${ }^{\circ}$ (participant 31).

According to participant 31, education has increased equality of opportunity in Wallis and Futuna. It appears that education has been experiencing a slow process of introduction and recognition within society but the following section will demonstrate that education is continuing to experience a slow process of integration and acceptance into society. It is evident that there has been a slow

\footnotetext{
68 « Faire partie de la France c'est faire partie du bloc. C'est la république et la république elle est égalitaire donc toute personne doit être considérée de la même manière » (participant 32).

69 « Tout le monde n'est pas égal à tout le monde» (participant 32).

$7^{0}$ « Tout le monde a les mêmes droits, tout le monde a droit à la réussite, ce qui bouleverse un peu tout ce qui ce passait avant » (participant 31)
} 
process in Wallis and Futuna to introduce education. Nowadays, it is still struggling alongside the traditional system.

"To succeed in studies is a success among others" ${ }^{71}$ (participant 31).

As a result, equal access to employment also continues to be a slow process of integration. Although the hiring process requires equal qualifications in France, in Wallis and Futuna the hiring process has acquired traditional criteria alongside qualifications.

"It's an arrangement between people and applications. It's not really an application process" 72 (participant 46 ).

"It depends if it's based on equal qualifications. At the territorial level, no. At the national level, yes" 73 (participant 28).

“There are graduates here who don't have a job and there are some that aren't qualified who have a job" 74 (participant 39).

This section will then be discussing the role of the traditional system of hierarchy, place, age and customary land ownership in the success and return of young graduates.

\subsubsection{Hierarchy}

\footnotetext{
${ }^{71}$ « Réussir au niveau des études, c'est une réussite parmi d'autres » (participant 31).

72 « C'est un arrangement entre des personnes et des dossiers. Ce n'est pas vraiment des concours. Mais après le niveau de postes est limité aussi. Il n'y a pas beaucoup de poste sur le territoire » (participant 46).

73 «Ça dépend si c'est à compétences égales - au niveau territorial non - niveau national oui » (participant 28)

74 « Il y a des diplômés ici mais qui n'ont pas de travail et il y en a qui sont pas diplômés qui ont du travail » (participant 39).
} 
Today, a person's place and status still remains an important aspect within society in Wallis and Futuna but this system of privilege of the royal and customary classes appears to have been weakened since the structures have been gradually transformed with contact with the western world.

Chiefs and royals are part of the aliki families and continue to be highly respected and recognised within the local communities. The concepts of power and privileged in this system are transferred through lineage. Hierarchy has maintained importance in Wallis and Futuna. 'Everyone has their place' and to 'come from a good family' where recurring themes in the interviews and are concepts that have retained precedence within society, particularly at the customary level. These families with aliki ties are also the only ones who are able to access customary or royal positions.

Hierarchy here is key in this research as it can also influence the return of young people from these families. Remaining in Wallis and may be more attractive to young people as they may have access to jobs of high responsibility. Nevertheless, the hierarchical system might be dissuading education or hindering return of these young people.

Although mentalities are evolving as elders are recognising the importance of young people within society and the benefits of education (participant 13), participants have stated that a graduate's access to political and customary responsibilities on the fenua may be hindered by their time spent abroad. For instance, in the customary system, participant 9 emphasised that a person living abroad is seen as being detached from the pure practice of customs on the fenua and could be seen as 'polluted'.

Participant 9 also stated that it is not education that will provide the student with customary legitimacy or provide access to customary positions. According to participant 9, a young returnee could then have an important position in the workplace but "not at in customary practices". Participant 17 stated that because she had lived abroad, despite her customary lineage, it would be very difficult for her to request customary responsibility. 


\title{
4.4.2 Customary Representation
}

Alongside this system of customary hierarchy, it appears that the monetisation of Wallis and Futuna, along with marriages between social groups, has caused an upsurge of wealthy and more dominant clans that do not necessarily have royal or chiefly ties (participant 3 and participant 12). Participant 3 compared it to the rise of the bourgeoisie in France, which has in a sense 'weakened' the presence of the customary and royal families in different aspects of society. It appears that privilege is no longer necessarily linked to a person's ancestry, rather it has to do with the families' presence in society (participant 17).

\begin{abstract}
"I think that it plays a part (dominant families) but not necessarily with lineage, not the royal blood and everything. It's more to do with the representation of the family. Now, it isn't about lineage because many have left, but it is about the customary representation of a family" 75 (participant 17).
\end{abstract}

Customary representation increases with customary gestures and gifts and is reliant on family participation. Larger families would thus be able to afford greater customary gifts, ultimately contributing to greater representation within society. As families become separated by migration, representation becomes much harder to maintain (participant 31). Participant 17 has very little family left in the territory and finds it difficult to keep up with customary gestures.

"You're only recognised really only if you belong to a group. You on your own, we don't know you. If you're

\footnotetext{
75 « Je pense que ça doit jouer mais pas forcément le sang - pas le sang royal et tout. C'est plutôt en terme de représentative de la famille. Maintenant, c'est plus le sang mais dans la mesure où les gens sont partis, la famille la plus représentative coutumièrement unie » (participant 17).
} 
alone, it's hard to make yourself known" ${ }^{76}$ (participant 31).

These new clans or dominant families have gained representation within society and has had a crucial influence on their access to employment (participants 31, 17). This is particularly relevant in the political sphere as elections are reliant on customary representation and presence in the community.

"Those who are elected are those who are more respected at the customary level (...). Everyone knows each other in Wallis, we recognise their surname. We'll respect them more because they come from a family that are in a powerful position"77 (participant 22).

According to participant 1 and participant 10, although it is important for children in dominant customary or political families to experience studying abroad, they are not as pressured to succeed.

"Because their social status, their social ranking, their social origins, enable them to hold the power later" 78 (participant 1).

This system would make it difficult for someone who has spent time abroad since they would not have been able to maintain links and representation within the community during their time abroad (participant 49).

\footnotetext{
$7^{6}$ « Tu n'es reconnus enfaite seulement si tu appartiens à un groupe. Toi seul, on te connait pas. Si tu es seul c'est dur de se faire connaître » (participant 31).

77 «Ceux qui sont élus, c'est ceux qui sont plus respecté au niveau coutumier, fin tout ce que tu veux quoi... Tout le monde se connaît à Wallis. On reconnait les noms de familles. On aura plus de respect envers eux parce qu'ils viennent d'une famille assez haut placé »(participant 22).

78 "Car leur positionnement social, leur rang social, leur origine sociale leur permet d'occuper, d'exercer le pouvoir plus tard » (participant 1).
} 


\subsubsection{Place and employment}

The system above has been colliding with the new system of equal opportunity and participant 18 believed that some families are against initiatives that could enable those in a lower financial and social standing to be trained and access employment in the territory as it would in a way disrupt the status quo. As a result, this hierarchy has been present in employment. A few participants have emphasised that someone from a noble, chiefly background or part of the dominant families would be more likely to find a job in Wallis or Futuna (participants 1, 10, 17, 18, 21, 33, 44). Some have even stated that employment is 'reserved' for these families (participant 10).

"We need to take into account the social factors that say that it's the dominant clans, the aliki, that have the positions"79 (participant 10).

"There are the aliki families here, the chiefly families, noble families. For those, most of their children find work more easily" ${ }^{80}$ (participant 44 ).

For instance, participant 21 stated that there was no one working in the primary schools that were not from 'aliki' families.

On the other hand, participants 18 and 17 have highlighted that because this system of noble and chiefly families has weakened, it is no longer necessarily those from a noble background who can access employment, rather it is the more 'dominant' or representative families. A person from a wealthy family is more likely to have family in the workforce and may be able to ensure that person's recruitment.

\footnotetext{
79 «Il faut tenir compte aussi du facteur social qui dit que c'est le clan dominant, c'est à dire les aliki qui ont les postes » (participant 10).

80 «Il y a les familles d'aliki ici, les familles de chefs, les familles nobles, ceux-là la plupart des enfants trouvent plus facilement du travail » (participant 44).
} 
Additionally, participants have highlighted that presence in custom or place in customary hierarchy is very different to presence in employment as it is 'completely separate' ${ }^{81}$ (participants 12, 39).
"The young graduate has nothing to do with being aliki or not aliki. There are many young people who have returned whose father was village chief or former king but it doesn't necessarily mean that he'll find work here" ${ }^{82}$ (participant 33).
"For me, this system is very old, we need to be able to live with the times. Nowadays, if you have a job and you want to do well in it, you're not going to let someone come and walk all over you because you've pursued higher education and it's not because someone with noble ancestry or a noble name that they're going to impose anything" 83 (participant 58).

Similarly, participants 12 and 31 have emphasised that qualifications now takes precedent over place in society.
"During a certain time, I know that we often gave employment to noble families so they didn't necessarily require diplomas or specific qualifications and often those positions were taken by people who come from royal descent. In fact, some are still in those positions. And at one point, it was complicated for the rest to find work but

\footnotetext{
81 « c'est complètement séparé » (participant 12).

82 « Le jeune diplômé n'a rien avoir en faite avec le fait d'être aliki ou pas aliki. Il y a des cas de jeunes qui sont revenus dont le père était chef de village, le père était ancien roi, c'est pas pour autant qu'il trouve un travail ici » (participant 33).

83 « Pour moi ce système est très vieux, il faut savoir vivre avec son temps. Là au temps ou on en est, si toi t'as un travail et tu veux prospérer dedans, tu vas pas laisser quelqu'un venir te marcher dessus parce que toi t’as fait de grandes études » (participant 58).
} 
it happens less and less because now, they're asking more and more for qualifications" 84 (participant 31).

However, it is debated in these circumstances whether qualifications are important. Participant 33 argued that in employment, qualifications are considered but status would still enter the criteria. This is especially the case for popular employment opportunities where competition is high.

"To be secretariat or assistant or head of department within the administration, there are many who have masters or undergraduate degrees." "If it's based on equal qualifications, it is the aliki that take it. It's always like that" 85 (participant 33).

\subsubsection{Networks}

On the other hand, some argued that qualifications are not necessarily given priority. Many participants stated that the interviews sometimes act as a 'tick' box but still allow candidates to be predetermined.

"Nowadays, we have interviews because it's imposed by the administration but we all know that in Wallis and Futuna, if you don't know anyone in politics, you won't have it (the job)" 86 (participant 33).

\footnotetext{
84 « A une époque, je sais qu’on donnait souvent des métiers à des familles nobles donc on exigeait pas forcément de diplômes ou de qualifications particulières et souvent ces postes là sont occupés par des gens qui sortent de lignée royale. D’ailleurs, il en reste encore. Et à un moment donnée, c'était compliqué pour le reste de trouver du travail mais ça ce fait de moins en moins parce que maintenant, ils demandent de plus en plus de qualifications » (participant 31).

85 «A compétences égales, c'est le Aliki qui l'emporte. C'est toujours comme ça. » « Mais pour être secrétariat ou être assistante de gestion ou chef de service dans l'administration, ils sont beaucoup à avoir des masters, de licences » (participant 33).

86 « Maintenant, on a un concours parce que c'est imposé par l'administration mais on sait tous à Wallis et Futuna si tu connais personne dans la politique tu l'aura pas » (participant 33).
} 
Participants have argued that nepotism is common and Employees find opportunities for family members more easily (participants 39, 18, 44, 33, 10, 1, $48,45)$.
"Most of the positions that are taken at the civil services are people from the same family. It's all from their connections" ${ }^{87}$ (participant 18 ).
"It's based on equal qualifications and then there is a bit of favouritism based on their familial situation, on this customary and political hierarchy" 88 (participant 44 ).

Many participants (participant 10, 144,33 ) stated that employment can be transferred from parents to their children when they retire.
"There are those that come from a good family and who know exactly that upon their return, they will inherit the position of their mum or dad. Those people don't have much to worry about" 89 (participant 10).

According to participant 44, children are sometimes sent overseas to study subjects that would provide them with the qualifications to take on their parents' jobs once they retire.

Additionally, there have been instances where young graduates were successful in the interviews but were sent away as they weren't from the 'right family' for the position (participants 10). Although these graduates are highly successful

\footnotetext{
${ }^{87}$ « La plupart des postes qui sont occupés à l'administration supérieure ce sont les gens d'une même famille. Ça a été du copinage » (participant 18).

88 « Les enfants de chefs de villages, d'élus, arrivent à occuper des postes plus facilement. avec diplômes quand même. Compétences égales et puis il y a un peu de favoritisme en fonction de cette situation familiale et de cette hiérarchie coutumière et politique » (participant 44).

89 "Il y a ceux qui viennent de bonnes familles et qui savent très bien qu'en rentrant ils hériteront du poste du papa ou de la maman, ceux-là ils n'ont pas trop de soucis » (participant 10).
} 
abroad, they would arguably have no chance to work in those jobs back home because of their social standing.

“Those who aren't part of the higher classes are those who work in the fields, go fishing, and work in handicrafts. Their children are going to study abroad, because they don't have the opportunity to succeed here" $9^{\circ}$ (participant 44).

Furthermore, this system makes it particularly challenging for the civil services to free existing positions because once someone has a job, those people often stay until retirement and 'on ne peut pas les virer' (we can't fire them) (participant 10) because they are from privileged families.

Others have argued also that high-level customary or political support and pressure can facilitate an individual's access to employment (participant 1, 11, 33, 44). If a person is not in a favourable social situation, participants have stated that customary offerings to people who can help find employment are common. There have been instances where people have started work as a gardener at the hospital and made their way up in the hospital facility as official personnel (participant 11, 33).

Many younger participants have highlighted their frustration and criticised the system for being unfair (participants 18,48 ).

"They need to stop discouraging us by hiring their cousin, their niece"91 (participant 48).

When participant 42 applied for a position on Futuna, she went through the applications process but was unsuccessful due to this system.

\footnotetext{
90 «Ceux qui n'ont pas de classe sont les gens qui vont travailler aux champs, à la pêche, travaillent dans l'artisanat. Leurs enfants vont aller faire des études, Parce qu'ils n'ont pas d'opportunité de réussite ici » (participant 44).

${ }^{91}$ « Faut arrêter de nous décourager en embauchant la cousine, la nièce » (participant 48).
} 
"I knew that when they conducted the interviews they knew already who they were going to choose. How so? Networks. It was that really. I was gutted that day. I wanted to leave"92 (participant 42).

"Someone that has a job and has family that has just arrived that don't have the right qualifications, they arrange things for their family. I think it's rotten. Really, it's not fair. There are some who work and struggle and who were waiting for that position, they're not recognised for it. They give the job to someone that has done nothing that's related to the job" ${ }^{93}$ (participant 22)

Participant 58 thought that this may also have a negative impact on organisations and businesses as the most suited people for the job are not taken.
"And when someone has left to pursue higher education and who is really suited for that job and you know that that person would have the potential to have a positive influence on the organisation, he comes back and he can't be taken for the job, it's really disappointing" 94 (participant 58).

\footnotetext{
92 « J'ai su que quand ils ont fait passer les entretiens, ils savaient déjà qui ils allaient choisir. Par rapport à quoi ? Connaissances. C'était un peu ça. J'étais dégoutée ce jour-là. Je voulais partir d'ici» (participant 42).

93 « Souvent, ce qui arrive, c'est le piston. Quelqu'un qui a un poste et qui a de la famille qui vient d'arriver alors qu'il n'a pas les diplômes pour, il arrange les choses pour sa famille. Je trouve ça salaud. Franchement, c'est pas juste. Il y en a qui pinaillent qui gallèrent et qui justement attendaient ce poste et ils sont pas reconnus pour ça. Ils ont laissés cette place pour quelqu'un d'autre qui n'a rien avoir » (participant 22).

94 « Et quand on a quelqu'un qui est parti faire de grandes études et qui a vraiment adéquat pour ce poste là et tu sais que cette personne-là va tirer les gens du personnel ainsi que l'organismes vers le haut, il arrive et il peut pas rentrer dans le poste, c'est vraiment décevant » (participant 58).
} 
Participants said that it was much more prominent 15-20 years ago to regulations, but it is still present (participant 38,44 ).

\title{
4.4.5 Customary Land Employment
}

In addition to the system highlighted above, customary land employment is a regular occurrence in Wallis and Futuna. Landowners can help ensure that members of their family are employed in the business that is on their land. The same entitlement is given to those who come from the same village where the business or organisation is located. Participants have stated that this can be frustrating because in many ways it puts a barrier to employment for qualified returnees if employment is reserved for landowners (participant 10, 43, 45, 48, 33 , 39).

\begin{abstract}
"We give jobs to families who own the land and often, those people aren't qualified. And it's even more complicated to find work because either way, they're going to hire family members or we're going to find someone who has a diploma who is married to a family member" 95(participant 31).

"If they had to choose between someone who is qualified and someone who comes from customary land, we're going to choose the one from the land even if they don't have the qualifications. (...) It's not frequent but it happens"96 (participant 39).
\end{abstract}

\footnotetext{
95 « On donne des postes aux familles propriétaires du terrain et souvent ces personnes-là sont pas qualifiés. Et c'est encore plus compliqué de trouver du travail parce que de toute façon, on embauche la famille ou on ira chercher une personne diplômée, mariée à un membre de la famille » (participant 31).

$9^{6}$ « Pour choisir entre quelqu'un qui a des diplômes et quelqu'un qui vient du foncier, on va choisir celui du foncier même si il a pas les diplômes. (...) C'est pas souvent mais ça arrive » (participant 39).
} 
This system, which was particularly condemned by participants on Futuna, causes difficulty for returning students in search of opportunities, especially if the student is not in a favourable position. According to participant 10, land ownership can increase a person's chances of finding employment but those who own a large amount of land tend to also be the most dominant families.

Non-compliance with the system by business owners or the civil service can lead to blockages and strikes where activity is put to a halt.

"Family is prioritised because if the family isn't satisfied, they're going to block everything. The family has the right to block all the activity" 97 (participant 31).

This occurred on a few occasions during my stay in Wallis and in Futuna and there have been a few more instances since. In November, the high school was closed for four days, along with the local education authority, because a job opening for a school monitor was given to a candidate and was not considered as a customary land employee. To quote a news article on this incident:

"The village chief of Mata Utu, the Tui Mata Utu, justified the obstruction of the school by stating that "the agreement between the high school and the village from 25 years ago assures an 'emploi foncier' to a local of Mata Utu", however he states "the vice-rectrice ${ }^{98}$ organised a concours for this position even though I had already appointed a candidate (a person) that has been working at the high school for a year and five months" 99 (Ferrante, 2015).

\footnotetext{
97 « La famille passe d'abord parce que si la famille n'est pas satisfaite, on bloque tout. La famille a le droit de bloquer toute activité » (participant 31).

${ }^{98}$ Head of department at the local education authority

99 « Le chef du village de Mata Utu, le Tui Mata Utu a justifié le blocage du lycée par le fait que "le bail entre le lycée et le village, qui date de 25 ans, prévoit un emploi foncier de
} 
Ultimately, the position was given to the person appointed by the chief.

The airport on Mata-Utu is also currently blocked and no flights have been allowed to depart or land due to a similar issue pertaining to customary land employment. They have estimated that 8o Futunans are in Wallis waiting to return home (Lataste, 2015). The situation has become so serious that the chiefs have requested a mediator to come from France and help solve the situation.

Customary land employment tends to apply to positions that would not require many qualifications. However, this is not always the case. Participant 48, said that prior to 2009, she would not have been allowed to work where she works now. Prior to a law passed in 2009, teachers from Wallis and Futuna were unofficially required to originate from the same village as the school. The law now states that teachers would be provided employment as a teacher at the school solely based on qualifications. However, most of the participants stated that in schools, any other type of employment that was outside of teaching and management is still reserved for local villagers.

Participant 33 believed that customary land is one of the most defining factors for employment in Wallis and Futuna.

"For example, at the hospital, all the personnel are all people who belong to the land even though it's supposed to be based on qualifications. This is really really serious because we're talking about people's health" 100 (participant 33).

Furthermore, participant 44 states that customary land employment agreements can hinder returning students in the future because as someone from the land or

surveillant attribué, sans concours, à un habitant de Mata Utu" or dit-il, "la vice-rectrice a organisé un concours pour ce poste alors que j'avais déjà désigné un candidat, (une personne) qui travaille au lycée depuis un an et cinq mois"»

${ }^{100}$ « Je prends le cas tout bête de l'hôpital, donc tout le personnel c'est toutes les personnes qui appartiennent à la terre alors que ça se passe sur la compétence. Ce qui est très très grave parce qu'on parle de la santé de la population de Futuna » (participant 33). 
family retires, this person will be replaced with another person from the same family or from the same village.

"If I take the example of this department, the highest qualification is a bac pro $^{101}$, no one else has a diploma. When the department was created, there was pressure to hire those people, or people from those families and who have since been replaced by other people from the same family"102 (participant 44).

Although, there is evidence that with time, this system may be changing.

"There was a nurse that came back not long ago. At the beginning everyone was shouting that she wasn't from the village. But she has the qualifications, so when she administers vaccinations, you don't risk anything" 103 (participant 33).

\subsubsection{Age, status and the right to speak}

It is also important to state here that a person's status, along with their age, can also define a person's 'right to speak' (la parole) in customary situations. For instance, an older chief would have the right to speak above a young person during a ceremony or a meeting. The right to speak is given by someone who is of higher 'status' and older, so a young person for instance would have to wait until they are given that right.

\footnotetext{
${ }^{101}$ a high school qualification

${ }^{102}$ «Je prends l'exemple au service ici, parmi nos 7 agents, le niveau plus élevé c'est un bac pro, tous les autres ce sont des agents non-diplômés. Parce que quand l'antenne a été créée en 2005, il y a eu des pressions pour embaucher ces gens-là, ou des gens de ses familles là et qui ont été remplacé par des gens de la même famille depuis » (participant 44).

103 « Maintenant il y a eu une infirmière qui est rentré il y a pas longtemps, au début tout le monde criait, elle n'est pas du village sauf qu'elle a les diplômes donc quand elle te vaccine tu n'as aucun risque » (participant 33).
} 
Age is an important factor in Wallis and Futuna and contributes to a person's status.

"Here, what brings you wisdom is your age" 104 (participant 9).

According to participants, in Wallis and Futuna, youth is defined by a person's marriage status and whether they have children. A young person would not have the same 'rights' as someone who is older, married and has children (participant 42). For this reason, it could be that they are less likely to be respected or their word listened to as normally, children and young people do not have the right to speak unless it is given to them (participant 1,45 ).

For a young person, it is important to know when and where to speak. For instance, in important customary ceremonies, every person would have a particular responsibility and place (participant 12).

This has also impacted representation of young people in politics and decisionmaking positions (participant 13) and when they are invited to take part in customary traditions, their ideas are not given priority (participant 12). Young people face obstacles particularly when putting forward projects or ideas because people need to follow the hierarchy (participant 49)

"We don't give them (young people) any importance in terms of what is happening" 105 (participant 42).

"In Wallis and Futuna, it is always the elders who have the last word and this is noticeable because when we see the problems in the territory, it isn't young people who are blocking, it's the elders" ${ }^{106}$ (participant 19).

\footnotetext{
104 « Ici, ce qui vous apporte la sagesse c'est l'âge » (participant 9).

105 « On leurs donne pas l'importance par rapport à tout ce qui se passe » (participant 42).

${ }^{106}$ «A Wallis et Futuna, c'est toujours les anciens qui ont le dernier mot et ça se ressent parce que quand je vois le problème au niveau du territoire - ce n'est pas les jeunes qui bloquent, c'est les âgés » (participant 19).
} 
"In the customary system, Futunan society, there are rankings which means that it is first the elders and it's only when we become wise that we can present our ideas. When we are between 25 and 30 years old, even 35 years old, we don't really have our say. It's a limiting factor" 107 (participant 44).

"As a young Futunan, you wait your turn to speak. It's first the elders and the elected politicians" ${ }^{108}$ (participant 38).

According to participant 12, young people would have the opportunity to speak up in other ceremonies reserved for the younger population and the importance of youth organisations were particularly evident on Futuna (participant 42).

This lack of voice can also stem from education and the individual themselves. Some young people when given the opportunity to speak are unsure of their ideas (participant 42). Some young people aren't used to being given the opportunity to speak (participant 31).

"I think that it comes from our education, it's stayed like that. I don't dare speak. I wait until they ask me a question and then I answer but I wouldn't say what I think, it wouldn't come from my own initiative. I wait until I am given permission. With the chiefs that's the way it is" 109 (participant 42).

\footnotetext{
107 "Dans la vie coutumière, sociétale futunienne, il y a des strates qui fait que c'est d'abord les ainées et c'est quand on devient sage qu'on peut donner ces idées. Quand on est jeune de 25-30 ans, 35 ans on n'a pas vraiment son mot à dire. C'est un facteur limitant » (participant 44).

${ }^{108}$ « En tant que jeune futunien, t'attends ton tour pour parler. C'est d'abord les vieux et les élus » (participant 38).

109 « Je le ressens moins personnellement quand il y a la réunion avec la chefferie ; pas qu'on me remette à ma place mais je crois que c'est avec l'éducation c'est rester comme tel. Je n'ose pas parler - j'attends qu'on me pose une question et là je réponds mais sinon ça viendrai pas de moi même de dire ce que je pense. J'attends qu'on me donne l'autorisation. Avec la chefferie c'est comme ça » (participant 42).
} 
"It's a huge problem here. We respect our elders, we don't dare speak. Young people don't express themselves enough. They lose all motivation from the start if elders don't support them either. But after it has to come from themselves as well, it's possible"110 (participant 22).

This system appears to be particular to customary situations but some participants have highlighted that it can transfer into the workplace. Although there is evidence that the system of privilege is slowly changing (participant 1 , participant 10), participant 1 thought that people's success at work is limited due to their 'right to speak' (la parole).

'CCommoners' need to succeed in their studies, to have a diploma, a masters etc., and for those children, many do not return to the territory because they know that even if they are 'covered in qualifications', they know that it will always be the children of the noble families and bourgeois, royal families that will be heard, listened to. It is their voice that is more important. And for them, there will always be this phobia, this fear of being put to the side and for this reason they will not have access to employment even if today we can see that there are many children of 'commoners' that have responsibility in the civil service. They succeed in the interviews but their voice is not important and that is something that is hindering" ${ }^{m 1}$ (participant 1).

\footnotetext{
${ }^{110}$ « C'est un gros problème ici. On respecte nos ainés. On n'ose pas parler - il y a un manque d'expression chez les jeunes. «Ils perdent toute leur motivation au dépars quoi si les vieux ne les encouragent pas non-plus. Mais après il faut que ça vienne de soit même quand même »-c'est possible » (participant 22).

III "Les gens du peuple se doivent de réussir leurs études, d'obtenir un diplôme, un master etc, et ces enfants-là beaucoup ne rentrent pas sur le territoire parce qu'ils savent que même si ils sont bardés de diplômes, ils savent que se seront toujours les enfants de la noblesse et la bourgeoisie, des familles princière qui seront entendus, écoutés, c'est leur parole qui prévaux. Et eux, il y a toujours cette phobie, cette peur de se voir mettre un peu
} 
This makes it particularly difficult for young people to assert themselves in their work if they are working with someone who is of higher status or older.

There is however evidence that this system is changing. There are people from different backgrounds that have been able to find employment (participant 1) and participant 19 thought that it does not impact a person's chance to succeed in the private sector at least as long as students persevere.

"For a young person from a modest family who has the financial support and can manage it well should be able to come and create something. I don't think it would impact their chances of success" 112 (participant 19).

\title{
4.5 "To make them return, we need to have the structures”
}

Participants have highlighted that associations with France and access to education has caused the system to change and adapt to the return of graduates and what has been brought back (participant 31).

\begin{abstract}
“Things are evolving thanks to education. Education is bringing change to society. We can feel it because there are more crises within the monarchy. There are more and more social conflicts. All that is characteristic of a society that is in complete mutation. It's the young people that are bringing us that" ${ }^{113}$ (Participant 31).
\end{abstract}

\footnotetext{
de coté et donc ils n'auront pas accès à l'emploi même si aujourd'hui on constate que beaucoup d'enfants du peuple occupent des fonctions. Ils réussissent des concours mais leur parole n'est pas importante et ça c'est un élément bloquant » (participant 1).

${ }^{112}$ «Qu'un petit jeune de bas rang qui arrive et qui veut créer un truc qui a eu là le soutien financier et qu'il arrive bien à gérer. Je ne crois pas que ça aura un impact dans sa réussite " (participant 19).

${ }^{113}$ « Les choses évoluent grâce à l'école. L'école apporte du changement au niveau de la société. On le sent parce qu'il y a plus de crises au sein de la monarchie. Il y a de plus en
} 


\subsubsection{Change within the confines of the system}

Participants have placed great importance on the return of young graduates to help the system progress but they find themselves confronted to an environment that is sceptical towards change (participant 9). Furthermore, participants 49 and 9 think the possibilities need to be explained to those in power in order for it to work because it is the system that is limiting progress, and ultimately, return.

"To make them return, we need to have the structures"114 (participant 6).

Manifestly, the possibilities of return and change have been met with a certain resistance. It is evident that some members of society are still concerned about returning students and what it means for the future of Wallis and Futuna.
"Why should we change system that is enduring?" 115 (Participant 12).
"My objective in all this, I want to preserve [the customary system] because otherwise, we are entering a system of globalisation, we are entering a system based on consumerism. Basically, we are just going to work to have 'this and that' but there will no longer be any cultural meaning to identify us" ${ }^{116}$ (participant 12 ).

\footnotetext{
plus de conflits sociaux. Tout ça c'est relateur à une société qui est en pleine mutation. C'est les jeunes qui nous apportent ça » (participant 31).

${ }_{114} «$ Pour faire revenir, il faut avoir les structures » (participant 6).

115 "Pourquoi changer un système qui perdure" (participant 12).

${ }^{116}$ « Moi mon objectif dans tout ça, je veux la préserver parce que sinon on rentre dans le système de la mondialisation, on rentre dans le système de société de consommation. C'est à dire, on va juste travailler pour avoir 'ça' mais il y a plus de sens culturel qui permet de s'identifier » (participant 12).
} 
Participant 42 thought that change is frightening for working people or people in higher positions.

“They don't want to create positions so that they don't have to hire young people that have another vision that is different to theirs" 17 (participant 42).

Additionally, participant 31 believed that the monarchy may fear what these new visions may mean for the structures and hierarchies of society.

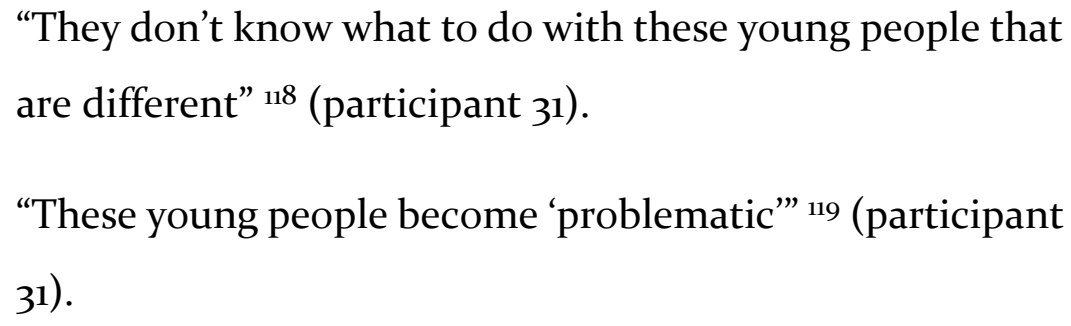

Participant 31 also thought that it is not only the noble classes that are concerned with these changes. The other unemployed 90 per cent of the population rely on the king and the monarchy, not on the republic.

The lack of clear direction for development is a significant debilitating factor for progress (participant 13) but there is an urgent need for development. The territory cannot always rely on the boat to deliver imports (participant 19) and the territory will not be able to afford to pay the salaries of the civil servants indefinitely without economic revenue (participant 7).

The current system has been scrutinised by many participants who have seen the coexistence of the two systems as a barrier to progress and development. Participant 9 thought that this system is interlocking with limited possibilities for innovations due to how the power has been distributed. The system indeed

\footnotetext{
${ }^{117}$ « Je pense que y a ça aussi au niveau de la politique, ils veulent pas créer des postes pour pas mettre des jeunes qui ont une autre vision des choses, différentes de la leur » (participant 42).

${ }_{118}$ « Ils savent plus faire avec ces jeunes qui sont différents » (participant 31).

119 «Ces jeunes deviennent 'problématiques' entre guillemets » (participant 31).
} 
could be a barrier for innovation as chiefs have the authority to decline projects (participant 9), but there is also evidence of limited change due to the introduction of French legislations (participants 6, 29).

"I think that it is a problem to do with governance"120 (participant 19).

"Having these two systems together is a total failure"121 (participant 6).

Participant 13 thought that the chiefs have good intentions and understand the value of education for young people but they do not see the full picture and possibilities and do not promote employment to enable return.

"In terms of development, it is difficult to get the message across that there is a need for it" ${ }^{122}$ (participant 13 ).

As a result, participants think change will be slow and will occur with the changeovers of customary and political elites and with the return of graduate as they take on these positions. Participant 13 believed that elites and elders still hold conservative attitude towards change. Authorities want to maintain peace and stability whereas new ideas and projects may be disruptive.

"It is possible but it will be long because we need to get it to be accepted (...). It will be the renewing of the chiefdom that will make mentalities change" ${ }^{123}$ (participant 13 ).

\footnotetext{
120 « Je pense que c'est un problème de gouvernance » (participant 19).

${ }^{121}$ « Avoir les deux systèmes ensemble, c'est un échec total » (participant 6).

${ }^{122}$ « En terme de développement, il y a une difficulté de faire passer ce message qu'il y a un besoin » (participant 13).

${ }^{123}$ « C'est possible mais ce sera long parce qu'il faut la faire accepter (...). Ce sera le renouvellement de la chefferie qui fera que les mentalités vont changer » (participant 13).
} 
Additionally, participants believed that there needs to be a changeover at the political level "because it really isn't working at the moment" ${ }^{24}$ (participant 22). Ultimately, participant 28 thought that it may be a problem of miscommunication between systems.

"Everything needs to change. (...) We need to shake things up. (...) we need to stop this system that's a bit corrupted" 125 (participant 58).

Many have highlighted the role of returning graduates to challenge this system. Participants are confident however that the system will continue to transform and provide further opportunities for young people but also for the development of the territory (participant 29, 22, 31).

"If really we were to be able to do that (change the system), I think that it would be good for the future. Everything would work out better. All the young people who are qualified, who have studied for years for nothing - We need to do it. We can't give up in our objectives, in our goals in life" ${ }^{126}$ (participant 22).

"We shouldn't be set in our ways, we can't bury ourselves in our customs, in our traditions, sometimes we need to progress" 127 (participant 58)

\footnotetext{
124 « Il faut remettre d'autre personne parce qu'ici ça marche vraiment pas bien là » (participant 22).

125 « Il faudrait que tout ça change. (...) Il faut faire bouger les choses (...) Il faut arrêter ce système un peu fraudieux » (participant 58).

${ }^{126}$ « Si vraiment on arrive à faire ça, je pense que ça serait bien pour plus tard. Tout s'arrangera mieux. Tous les jeunes qui sont diplômés qui ont fait des années d'études pour rien. Il faut le faire. Il ne faut pas lâcher prise dans nos objectifs dans nos buts dans la vie » (participant 22).

127 « Il faut pas rester bloqué sur soit, il faut pas terrer dans ses coutumes, dans ses traditions, parfois il faut évoluer » (participant 58).
} 
For this to happen, however, graduates need to be motivated and persevere (participants 4, 22, 50, 58, 33, 12).

"I think that it is a shame in Wallis and Futuna. I think that it could evolve if we try to put a little bit of our own involvement in it. I know some who have a lot of potential but they don't use it. It's really a shame. They could go far and make Wallis and Futuna develop a little bit" ${ }^{128}$ (participant 22).

“There are things to develop here but we need motivation to do it" 129 (participant 50).

There is evidence of motivation and ideas for the future amongst the younger populations.

"Our idea is to create an association or a foundation to gather all the young people here who have only one idea; to develop Futuna" ${ }^{130}$ (participant 33).

"I really want there to be a follow-up (of the students) and that these qualifications return to the islands, we need it"131 (participant 58).

“My project that I want to develop later, it's for here. It's so that there is more employment in Wallis, so that there are

\footnotetext{
${ }^{128}$ «Si vraiment on arrive à faire ça, je pense que ça serait bien pour plus tard ; Tout s'arrangera mieux. Tous les jeunes qui sont diplômés qui ont des qnnées d'études pour rien. Il faut le faire. Il ne faut pas lâcher prise dans nos objectifs dans nos buts dans la vie «participant 22).

129 « Il y a des trucs à développer ici mais faut de la volonté pour le faire » (participant 50)

130 « Notre idée c'est faire une association ou une fondation pour récupérer tous les jeunes là qui n'ont qu'une idée qui veulent développer Futuna » (participant 33)

${ }^{131}$ « J'ai vraiment envie qu'il y ait un suivit et que ces compétences-là retournent aux isles, on en a besoin » (participant 58 ).
} 
no longer young unemployed people that stay at home" 132

(participant 22).

However, this return and visions for the future from young graduates will need to be matched with a new and welcoming system.

“Things need to change together" 133 (participant 58).

For instance, in Alo on Futuna, participant 42 said that there are young people who are planting Kava for the traditional ceremonies, tauasu ${ }^{134}$ which they could start selling if politicians would enable it with new financial policies ${ }^{135}$.

“Adults should encourage young people too" ${ }^{136}$ (participant 42 ).

Nevertheless, participants argued that this transformation would not be without struggle and it is up to society to find equilibrium between the traditional system and modernity (participants $42,13,5$ ).

"It needs to be well received as well" 137 (participant 58).

"We can mix modernisation and tradition and find the right balance and tell our young people that we can't stop them from changing. It's normal, it's life, and it's

\footnotetext{
${ }^{132}$ « Moi mon projet que j'ai envie de faire pour plus tard, c'est pour ici. C'est justement pour avoir plus d'emploi à Wallis. Pour plus qui ait des jeunes au chômage qui sont chez eux » (participant 22).

133 « Il faut faire les choses ensemble » (participant 58).

134 Gathering where people drink Kava (Huffer, Leleivai, \& Sanchez, 2001, p. 157)

135 « Je crois que le jeunes d'Alo veulent créer des plantations et de les vendre à ceux qui veulent, les plantations de Kava pour le tawasu, et je crois bien qu'à Alo il y en a qui le font. Ils ont fait des plantations là il y a pas longtemps. Si ils le vendent se serait bien et se serait bien aussi que ce genre de mouvement ouvre les yeux aux autorités politiciens et qu'ils créent ou alors qu'ils investissent dans les machines parce qu'ils utilisent beaucoup pour permettre à ces jeunes-là de fabriquer, de vendre eux même le Kava » (participant 42).

${ }^{136}$ «Il faudrait aussi que les adultes encouragent » (participant 42).

137 «Il faut que ça soit bien reçu aussi » (participant 58 ).
} 
globalisation that causes it. But in some ways, we can't lose our soul, our identity"138 (participant 5).

However, in order for this to happen, there needs to be a return.

"If we want to talk about development, we need a workforce, a population" 139 (participant 13).

\subsubsection{Return of graduates}

However, as returning graduates have highlighted, return is difficult because they have changed and they struggle to find a place in society.
"Nowadays, as a young person, we're encouraged to leave, to study so we go. The problem is that when we return, we don't have our place in society. Whether it is in the administration or in custom, we don't have our place" 140 (participant 38).

As participant 31 highlighted, education may have disrupted the system of 'place' in society in the territory but education still does not affect a person's place in society, rather a person's place is left unchanged upon return (participants 1, 44, 49).

Return could be seen as a threat to the status quo.

"We look at them in a certain way and we think that they come back thinking they know everything because they

\footnotetext{
${ }_{138}$ «Si on peut concilier modernisation et tradition et trouver un juste équilibre et dire aux jeunes on peut pas vous empêcher à évoluer. C'est normal, c'est la vie, c'est la mondialisation qui veut ça. Mais quelque que part aussi, il faut pas perdre son âme » (participant 5)

139 "On veut parler de développement, il faut de la main d'oeuvre, de la population" (participant 13).

140 « Aujourd'hui en tant que jeune, on est encouragé de partir et à faire des études. On y va. Le problème c'est qu'en revenant, on a pas notre place dans cette société. Que se soit administratif, que ce soit coutumière, nous on a pas notre place » (participant 38).
} 
have a degree. They struggle to reintegrate into the system. They are put back in their place and told 'it's not because you have a diploma that you're more 'intelligent' than the others"” ${ }^{141}$ (participant 44 ).

Some participants have argued that scepticism towards return appears to affect a graduate's ability make use of their education at home (participants 19, 46).

"Young people who come here, they don't have any representation. They come here, they wait. Often elders who are at high-level jobs, they 'short-circuit' young people. They say they'll come back and be highbrows. It's often like that. There's also that that's blocking. It's a minority but it exists"142 (participant 19).

A common observation by participants was returnees were often accused of being French or papalagi if their ideas opposed the cultural protocol or ways of doing. Although, there are young people who persevere and are able to challenge the hierarchy; they can be seen as rude and disrespectful of the culture and ideas and change are unlikely to be well received (participant 1, 42, 45).

"We need to adapt and not come back and impose" ${ }^{143}$ (participant 45).

"(They said) 'she wants to impose, she wants to be French because she wants to come back, she wants to be intelligent even though there's the customary chiefs who

\footnotetext{
${ }^{141}$ « ils ont du mal, on les regarde d'un certain œil en se disant voilà eux ils arrivent en croyant tout savoir parce qu'ils sont diplômés et ils ont du mal à se réintégrer dans le système. Il sont remis à leur place, en leur disant que 'c'est pas parce que t'as un diplôme que t'est plus « intelligent » que les autres' » (participant 44).

142 « Les jeunes qui arrivent ici, ils n’ont pas de représentativité- ils viennent là, ils attendent. Souvent les gens âgés qui sont à des postes de responsabilité -court-circuitent les jeunes - ils disent ils vont venir faire les intellos - souvent c'est comme ça - c'est ça aussi qui bloque - c'est une minorité mais ça existe » (participant 19).

143 « Il faut adapter et ne pas venir se poser » (participant 45).
} 
are intelligent, they have the wisdom of the elders"' 144 (participant 33).

As a result, many graduates are required to merge back into society or readapt what they have learnt in order to introduce new concepts within the confines of the system. Having to readapt knowledge is particularly true for returning graduates since subjects studies abroad were not tailored to the context of Wallis and Futuna.
"After, when they return, there is what we learn at school and what is done here. For the development of Wallis, it's not really what we learn in New Caledonia or France, you can't necessarily apply it here" 145 (participant 2).

Many participants thus argued that students needed to filter what they had learnt abroad to fit the local context.

\begin{abstract}
"Perhaps returning graduates could bring a new vision from the world outside but they need to demonstrate a logical analysis. They can't do anything they want either" ${ }^{146}$ (participant 19).

"To have a papalagi way of thinking and a Wallisian way of thinking, we need to be able to merge them because I think
\end{abstract}

\footnotetext{
144 « Elle veut s’imposer, elle veut être française parce qu'elle veut venir, elle veut être intelligente alors qu'il y a les chefs coutumiers qui sont intelligents, ils ont la sagesse des anciens » (participant 33).

145 « Après quand ils reviennent, il y a ce qu'on apprend à l'école et puis ce qui se fait ici. Donc le développement de Wallis, ce n'est pas forcement ce qu'on apprend en Nouvelle Calédonie ou en France, ça s'applique pas forcement ici » (participant 2).

${ }^{146}$ « Peut-être que les diplômés qui rentrent sur l'île apportent une nouvelle vision du monde extérieur et il faut aussi qu'ils montrent une analyse logique. Faut pas qu'ils fassent n'importe quoi non-plus » (participant 19).
} 
that mixing these two things is a good thing" 147 (participant 58).

Participant 45 came back after her first year of master's in education but she found that in Futuna, it was quite difficult to transfer directly what she had learnt.
"I studied in the metropolis and what I studied, I can't really transfer it to Futuna because it's a different way of thinking. I think that it is for me to adapt what I learnt" ${ }^{148}$ (participant 45).

In this case, participants have argued that it is up to the graduates to return and adapt accordingly, rather than try and change the system (participants 1,45 ).

For those who have to return to the territory, participants emphasised that their degrees acquired overseas are not used in the territory. Sometimes qualified people who return find themselves without employment, or with employment that doesn't correspond to what they studied.

\begin{abstract}
“There are young people that come back from France and that have done advanced studies and they come back here and they are not recognised. They have to take care of their parents and they have work that doesn't correspond to what they have studied. That's shame. For example, they work in security, in small shops, they sell tubers, maniocs in the markets. They have good qualifications but they have nothing to do with what they are doing today. It's
\end{abstract}

\footnotetext{
147 « Avoir une mentalité papalagi et une mentalité Wallisienne, il faut savoir les fusionner parce que je pense que la fusion des deux choses est une bonne chose » (participant 58).

${ }_{148}$ «J'ai étudié en métropole, et ce que j’ai étudié, je peux pas forcément transférer ça à Futuna parce que c'est une autre mentalité. Je crois que c'est à moi d'adapter ce que j'ai appris » (participant 45).
} 
quite shocking. I think it's sad. They've wasted those years for nothing" 149 (participant 22).

As established in previous sections, young returnees (participant 19) have demonstrated that it is possible to reintegrate and readapt knowledge learnt abroad to suit the system and create an activity. Participant 54 also believed that young people are being integrated within the administration despite having spent time abroad. This was indeed evident from some of the younger participants working for the administration.

Others have argued that in order to fully benefit from ideas education abroad, graduates need to gain more experience before returning. It was evident from interviews with the younger participants that students tend to return before finishing their degrees or as soon as the degree is completed.

As many have highlighted, experience from abroad is what is going to help the territory progress and develop, but according to participant 41, when graduates return too soon, they return without adequate experience for the jobs available in Wallis and Futuna. Participant 41 thought that graduates should stay abroad for a minimum of ten years to gain more experience. He also highlighted that often, those who had waited a few years before returning were in high-up positions and had been able to create something.

Others stated that this is problematic because the longer people stay abroad, the more likely they are to permanently settle (participant 14, 15, 12). Participants also argued that young people often felt the need to come home to look after their parents and families and staying abroad for longer would not be a possibility (participant 28). In fact, for many of the participants in the research, family

\footnotetext{
149 « Il y a des jeunes qui reviennent de France qui ont fait de grandes études et ils reviennent ici et ils ne sont pas reconnus sauf parce qu'ils s'occupent de ses parents et ils ont un travail qui leur correspond pas. C'est ça qui est dommage. Par exemple, ils travaillent dans la sécurité, dans des petits magasins, ils font des ventes de tubercules, magnoque dans les stands. Ils ont de bons diplômes pourtant qui n'ont rien avoir avec ce qu'ils font aujourd'hui. Ça me choque quand même. Je trouve ça triste. Ils ont perdus des années pour rien » (participant 22).
} 
responsibilities were one of the most common factors for early return of students (participant 6).

"Often, you have young students that come back because they know that their family is struggling and they want to come to find work and help increase a little bit the family's standard of living" ${ }^{150}$ (participant 3).

Participant 22 also stated that timing isn't always in the control of the graduates due to their responsibilities within the family. When they need to take care of their parents or families, they are required to return.

"Even if they are working, they have made a life but they are forced to move everything, to rebuild their life" ${ }^{151}$ (participant 22).

In addition, in Wallis and Futuna it is crucial for people to be in the territory to increase their chances of finding employment. Sometimes timing is prioritised over qualifications. For example, participant 48 was never trained as a teacher but found a job as a substitute teacher because she was there at the right time. This is the reason why students often return as soon as they hear of a job opening, whether they have finished their studies or not. In fact, many do return for a couple of years in the hopes of finding employment and leave again if they are unsuccessful (participant 39, 1, 44).

\subsection{3 "We're destined to live abroad"}

In fact, return is not a common choice for graduates. Participant 1 suggested that only about one per cent of students return a year because many graduates are deterred by the financial, political, social and customary factors and drawn to

\footnotetext{
${ }^{150}$ « Très souvent vous avez des jeunes qui reviennent parce qu'ils savent que leur famille est en difficulté et ils veulent revenir sur place pour trouver un travail et aider remonter un petit peu le niveau de vie de la famille » (participant 3).

${ }^{151}$ « Même si ils sont pleins dans leurs travails, ils ont fait leur vie mais ils sont obligés de tout déménager, de tout refaire leur vie » (participant 22).
} 
modernity, employment and financial stability abroad. Participant 10 stated that people left as a reaction to the current reality in the territory.

“Because economically we don't have the means, because customary lands are beginning to become rare because we shared too much of it, because I can no longer live on my land, because I'm fed up of living with my parents, because this clannish way of living which was a reality up to the 1960 s but is beginning to crumble because we need to be autonomous, we need to assert ourselves. But this is not possible because we all live one on top of the other so I'm going to leave" ${ }^{152}$ (participant 10).

Participants 3, 48, 17 further expressed that custom sometimes can make young people leave, particularly couples, because of the pressure to share their salary and participate in ceremonies. Others have also argued similarly that financially, custom is a burden as a high proportion of their salaries goes towards supporting the community, participating in ceremonies and giving gifts to family members. Custom had gained monetary value and has become an added expense and a responsibility (Participant 50, 31).
"There are many families that are isolated because they don't have the financial means, because they don't have this possibility to be part of the family clan because what they will bring (customary gift) won't have any economic value"153 (participant 31).

\footnotetext{
152 « Parce que économiquement on n'a pas les moyens, parce que les terres coutumières commencent à se rarifier parce qu'on a trop distribué, parce que je ne peux pas vivre sur ma terre, parce que j'en ai marre de vivre avec mes parents, parce que ce mode clanique qui était la réalité jusque dans les années 60 et commence à se déliter parce qu'on a besoin d'autonomie, on a besoin de s'affirmer. Comme ce n'est pas possible parce qu'on vit les uns sur les autres, et bien je m'en vais» (participant 10).

153 «Il y a beaucoup de familles qui sont isolés parce qu'ils ont pas les moyens financier, parce qu'ils ont plus cette possibilité de faire partie du clan familial du fait que ce qu'ils vont apporter n'ont pas de valeur économique » (participant 31).
} 
Nevertheless, this argument is contested and some have said that custom is a choice and diasporas abroad said that culture is replicated (participants 33, 7).

"Custom has nothing to do with people leaving. In Nouméa, they continue to practice traditions. If some say that it is expensive, it's them that make it expensive. Tradition does not ask us to pay that much. It's people that make it expensive" (participant 35) ${ }^{154}$.

"There are some who say that they leave to escape custom but those who leave supposedly to escape custom, they practice it in Noumea or in the metropolis, it's not an excuse to leave" 155 (participant 39).

On the other hand, some young people stay in the metropolis because of the social status and networks that dictates one's access to employment (participants $3,44,58)$.

"There are also young people who leave because their parents weren't in a disadvantaged situation here and for them success is elsewhere" ${ }^{156}$ (participant 3).

“They are probably factors that force young people to stay overseas because they know that they won't find work in Wallis. They know that the job that they wanted was already taken. They know that they won't get the job straight away. They know as well that it's the system that

\footnotetext{
154 « La coutume n’a rien avoir au départ. A Nouméa, ils sont en train de faire la coutume. Si il y en a qui disent que ça coute cher, c'est eux qui font que ça coute cher. La coutume ne nous impose pas de payer autant. C'est les gens qui exagèrent» (participant 35).

155 «Il y en a qui disent qu'ils partent pour fuir la coutume mais ceux qui partent soit disant pour fuir la coutume, il la font même à Nouméa ou en métropole, c'est pas une excuse pour partir» (participant 39).

${ }^{156}$ « Après il y a des jeunes qui partent parce que leurs parents étaient dans une situation un peu défavorisé ici et pour eux le succès est ailleurs » (participant 3).
} 
meant they took someone with fewer qualifications even though you took the required studies, you have the right diploma and you're not taken, it's better to stay here (overseas)" 157 (participant 58).

Conversely, others prefer not to return if there is no guarantee of employment.
"I would like to return to Wallis but if I don't find good employment straight away, I don't want to waste my time pointlessly by going back there. Maybe I'll go back for the holidays but I would like to gather enough capital that would help me return to Wallis" ${ }^{158}$ (participant 58 ).

On the other hand, some graduates stay abroad to exploit economic opportunities. Participant 7 thought that young people have more incentives to stay abroad as they are offered more benefits, stable employment and help complement labour shortages in their destination.

\begin{abstract}
"New Caledonia always offers more than what we give in the territory. Young people are attracted to the wages, offers that encourage our youth to stay in New Caledonia” 159 (participant 7).
\end{abstract}

"I have four children. There is only one that is staying here with me. I ask them if they don't want to come and they

\footnotetext{
157 «C'est probablement des cas qui forcent les jeunes à ne pas rentrer parce qu'ils savent qu'ils vont pas trouver de boulot à Wallis, ils savent que le postes qu'ils voulaient est déjà pris, ils savent qu'ils l'auront pas tout de suite, ils savent aussi que le système qui a fait qu'ils ont pris quelqu'un avec les moindres compétences alors que toi tu as fait tel parcours, tu as tel diplôme et que t'es pas prise, mieux vaux rester ici » (participant 58 ).

${ }_{158}$ « Je voudrais rentrer à Wallis et si je ne trouve pas d'opportunité je veux pas gaspiller du temps inutilement en rentrant la bas peut-être que j'irai pendant les vacances mais j'aimerai construire un capital qui va faire qu'une fois que je rentrerai à Wallis » (participant 58).

159 « La Calédonie propose toujours plus que ce que nous donnons au niveau du territoire. Les jeunes sont attirés par les salaires, des offres qui incitent nos jeunes de rester en Nouvelle Calédonie » (participant 7).
} 
tell me absolutely not. Why? Because our children are used to something else than what they experienced here. (...) If I had never worked ... I would have left already" 160 (participant 7).

"Once they are caught in the employment market elsewhere, they're not really motivated to return... And they're not sure to find something once they return to Wallis" ${ }^{161}$ (participant 58).

Moreover, in Wallis and Futuna, employment that is available often requires advanced studies, whereas in New Caledonia and metropolitan France, there is access to employment that requires fewer qualifications, if any. Students can give up on their studies and find employment where they are and end up staying there because they know that given their qualifications, they wouldn't have access to employment back home (participant 7).
“Those who don't succeed (in their studies) leave too because in France they have so many qualified people that they need people that aren't qualified. Wallisians, in New Caledonia, for everything that is construction is mostly done Wallisians and Futunans. They adapt according to their qualifications or their lack of qualifications" 162 (participant 3).

\footnotetext{
160 "J'ai quatre enfants, il y en a un seul qui reste ici avec moi. Je leurs demande si ils ne veulent pas revenir, ils me disent surtout pas. Pourquoi? Parce que nos enfants sont habitués à autres choses qu'ils avaient vécus ici. (...) Si moi je n’avais pas travaillé ..., je partirais déjà" (participant 7).
}

\footnotetext{
${ }^{161}$ « Une fois qu'ils sont pris dans les engrenages du marché du travail ailleurs qu’à Wallis, ils sont pas forcément motivés de rentrer... Et ils sont pas très certains de trouver quelque chose une fois en rentrant à Wallis » (participant 58).

162 «Ceux qui ne réussissent pas partent aussi parce que ça se trouve qu'en France on a tellement de gens qualifiés, qu'ils ont besoins de gens non-qualifiés. Le Wallisien, en NC,
} 
Furthermore, as discussed in previous sections, graduates are less likely to return if they have acquired qualification that are too advanced and specialised (participants 10, 13, 58, 22), or too generalist and common (participant 44).

As a result of permanent settlement by young students, there is a rapid effect of 'chain migration' occurring as grandparents leave Wallis and Futuna to join their children and grandchildren abroad (participant 9, 34, 35).

"Before young people would send money to the parents and now they're sending money to pay for the flights" 163 (participant 7).

According to participant 7, this is often the case for those that aren't in a stable financial position in Wallis and Futuna. In France or New Caledonia, people have access to benefits that they do not have access to in the territory (participants 7 , $18,3)$.

Indeed, it is apparent that many simply can no longer afford to live in the territory because their family is shrinking or no family member has any form of secure employment in the territory. Thus for a family that struggles financially, having a child abroad is their way out of the territory. This is also sometimes the case for parents that are employed. Some people join their children overseas as soon as they retire because they are alone in the territory.

Although territory wants to support returnees, the limited established structures in the territory and the size of the territory mean that permanent settlement abroad will need to continue (participant 13, 44).

tout ce qui est construction est majoritairement Wallisien et Futunien. Donc, ils s'adaptent selon ses qualification ou son manque de qualification » (participant 3 ).

163 « Avant les jeunes renvoyaient de l'argent aux parents et maintenant ils envoient de l'argent pour les billets » (participant 7). 
"We're going to prioritise return but within a certain limit"

164 (participant 13)

"We have so many young people here who leave and even if they came back with all the specific qualifications, we would struggle to recruit them, financially the territory does not have the means to" 165 (participant 44).

Wallisians and Futunans will continue to migrate.

"It is a population that is destined to live abroad, to leave the islands, we have to" ${ }^{66}$ (participant 58 ).

\subsection{Summary of findings}

The findings described the phenomenon of migration for education in Wallis and Futuna through the insights of research participants in the territory and in New Caledonia. An extreme diversity of perspectives arose from the interviews and demonstrated how participants' understanding of the phenomenon were socially constructed by their own experiences, influences and interpretations. The impacts of education and migration in Wallis and Futuna are viewed in different ways by different people.

The findings have clearly presented that there is no clear answer to the research as arguments from participants significantly varied. A conclusion can be drawn up however in terms of the strategic use of education and other resources in the hinterland in order to benefit different levels of society locally, as will be discussed in the following chapter.

\footnotetext{
164 «On va privilégier le retour mais dans une certaine limite» (participant 13).

165 « On a énormément de jeunes ici qui partent et même si ils revenaient tous avec des diplômes spécifiques, on aurait du mal à les recruter, financièrement, le territoire n'a pas les moyens » (participant 44).

166 «C'est une population qui est vouée à s'expatrier, à sortir de l'̂lle, on est obligé » (participant 58).
} 


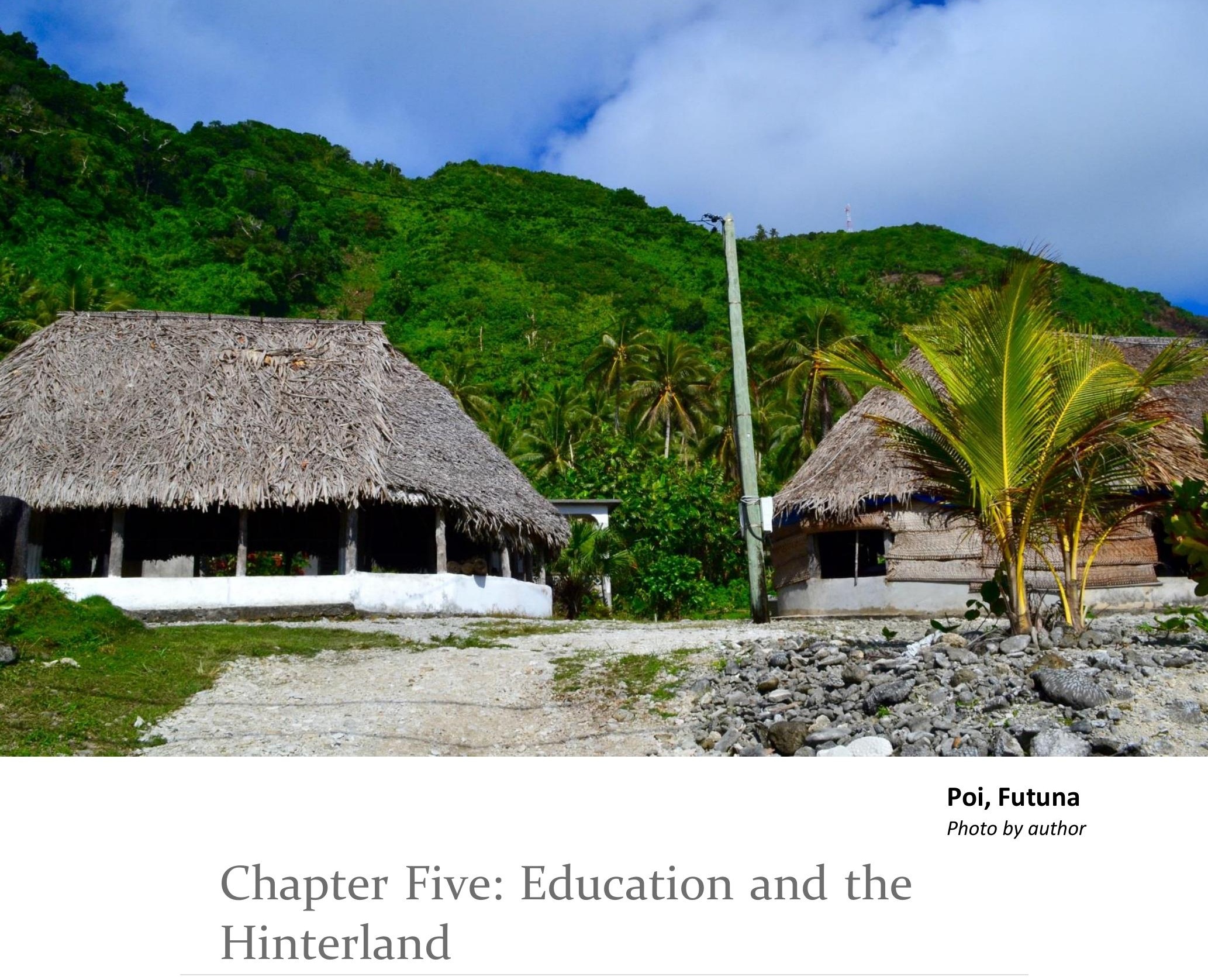




\subsection{Introduction}

The findings above were structured in a way to facilitate answering the key questions of the research listed below. This discussion will seek to address these questions indirectly while drawing from the findings and literature review.

* What are the initiatives to support education and training of Wallisians and Futunans and are they successful?

- What opportunities are there upon the return of students/ graduates?

* Are there limiting factors for the return of students and possible economic activity in the territory?

The literature highlighted that migration could be caused by underdevelopment (Portes, 2008), could be a 'short-term safety valve' (Portes, 2008; Connell, 2008, 2010; Maclellan \& Mares, 2006) and had the potential to drive development (Portes, 2008; Stark, 2004; Stark et al., 1997). The findings suggested that all three were occurring in Wallis and Futuna and education had an important role in all three concepts.

These findings have been accentuated by the use of education to provide the territory with further access to 'exploit' (Bertram \& Watters, 1985) the hinterlands (Baldacchino, 2006) of France and the DOM COM. Migrants are the key medium through which this could be achieved.

The research also revealed that, as evident in the literature, the decision to migrate is dependent on a variety of factors, not only economic factors (Cohen \& Sirkeci, 2011), and migrants have had an important role in shaping a place and its structures (Skeldon, 1997). However, findings also supported that migration is one variable amongst many others and the extent to which migrants can shape a place is subjected to external factors such as complex economic, political, social and cultural components (Appleyard, 1989; Castles \& Miller, 2009; Connell, 2010). 
Additionally, the way in which the hinterland is used is ultimately dependent the interaction between migrants and the system whereby the system has a critical influence on the future decisions of graduate migrants but graduate migrants concurrently have leverage over the future of the system.

I have divided this discussion into two main themes. The first theme identifies a simultaneous occurrence of brain drain and brain gain in the territory and the second theme gathers the social, cultural and structural factors that have impacted the benefits of education in the territory.

\subsection{Education and Migration}

According to much of the literature, education is seen as an opportunity to increase human capital. Human capital is deemed as a "strategic" and "vital" resource (Adams \& Douglas, 1968, p. 1; Williams \& Baláz, 2008) for the development of an economy (Boulding, 1968; Williams \& Baláz, 2008). In Wallis and Futuna, the system is providing just that; an equal opportunity for young people to invest in their own educational development and the opportunity to access employment. In this context, access to education is not only an opportunity but is also a necessity for employment in the hinterlands and in Wallis and Futuna. Here, findings have affirmed some of the literature, that education has been another inevitable extension of this embedded culture of migration (Connell, 2008) and has caused an additional push towards the metropolis (Sharrod, 1993). However, as Kindelberger (1968) suggests, education abroad has placed uncertainty on the possibility of the territory to benefit from increased human capital.

In this research, Wallis and Futuna is simultaneously experiencing brain gain and brain drain. The system has been enabling the return of educated migrants whilst constraining this return at the same time. Faced with this system, young migrants have responded by weighing up the positives and negatives of emigration over returning to the islands. 


\subsection{1 brain drain}

According to the literature, loss of capital through emigration could be highly detrimental to the potential of development of the sending nations (Adams Jr, 2003; Adams \& Douglas, 1968; Carling, 2008; IOM, 2005; Kapur \& McHale, 2005). The loss of such capital has proven to be particularly detrimental to smaller states and Pacific Islands (Beine, Docquier, \& Rapoport, 2008; Beine, Docquier, \& Schiff, 2008; Brown \& Connell, 2004; de la Croix et al., 2014; Gibson \& McKenzie, 2011, 2012; Reddy et al., 2004; Schiff, 2005). The literature would stipulate that whether Wallis and Futuna can benefit from this human capital is highly dependent on the return of graduates. However, it appears that Wallis and Futuna is losing many young graduates to France and the DOM COM. Here the brain drain is perpetuated due to factors at different levels of the system that influence a young migrants' decision to remain in the hinterland.

The role of educational systems in the brain drain effect has been significantly lacking in the literature. However in the findings of this study, the French educational system has a striking responsibility in shaping the paths of graduates and ultimately in determining both the migrants' decisions to return and their opportunities for return. The system French educational system needs to be used in the way it was intended otherwise the students' future access to education or access to employment may be limited or redirected (ref. section 4.3.1). In Wallis and Futuna, the restriction of the education system has led many into redirected study pathways or caused students to drop out. This is particularly due to classroom capacity limits, family networks overseas, financial expenses and lack of understanding of the system.

It also appears that the employment available in the territory is predominantly higher skill employment and there is limited waged unskilled employment. Whereas in the hinterlands, there are many more opportunities at different levels of qualification- a concept that contradicts brain drain literature. Wallisian and Futunan migrants are therefore complementing the skilled and unskilled labour markets in the destinations. 
Issues to do with skills return in the sending countries have been particularly highlighted in the literature. Kindleberger (1968) and Skeldon (2008) emphasised the possibility of graduates returning with unsuited skills. Connell (2008) similarly wrote about difficulties with the 'diploma disease' or 'training conundrum' where graduates are over qualified for opportunities at home. Benjamin (1993) also stated that degrees acquired abroad were sometimes not recognised at home, therefore limiting the potential use of such qualifications. The literature here particularly resonated in the findings. As many participants highlighted, the limited opportunities in Wallis and Futuna mean that returning graduates are very restricted for choice and their degrees do not often match the requirements in the territory. In Wallis and Futuna, returning graduates may have degrees that are too specialised for opportunities in the territory. Returnees then may find themselves in employment that does not match their level of education. The findings further highlighted that returnees sometimes return with degrees that are too general or common. Returning graduates are then faced with high competition for employment given the limited opportunities. Additionally, the findings emphasised that what is learnt abroad is not always appropriate for the situation in Wallis and Futuna, for instance in teaching or business development. The knowledge is not always useful back home or needs to be adapted. Furthermore, degrees acquired outside of France and the DOMCOM are not always recognised back home. This seems to have limited the potential for further regional exchanges as degrees from Australia and New Zealand were found to be discredited in Wallis and Futuna. Additionally, a significant hindrance for students and the territory is the fact that there has not been a report assessing employment requirements.

Research also demonstrated that this skill collides with a system that does not have the capacity or structures to welcome return. Narrow employment opportunities on the islands have deterred many skilled and unskilled migrants from returning. In the Pacific in particular, a lack of opportunities at home was identified as a strong incentive for migration in the literature (Benjamin, 1993, Rallu, 1994). 
Although the public sector continues to provide attractive employment opportunities due to higher wages and secure employment, it has been struggling to meet the increasing demand for employment and the decreasing population has resulted in a declining need for positions in this sector. The high wages and secure employment opportunities in the public sector have acted as a disincentive for employment in the private sector. In Wallis and Futuna, high taxes, lower wages in the private sector compared to the public sector, limited export opportunities also provide little incentive for graduates to invest in development and create projects back home, as similarly identified by (Bertram and Watters, 1985). The system also appears to present additional challenges for the creation of activities in the territory pertaining to custom, politics and finance. Additionally, the research demonstrated that the gift and barter economies have caused difficulty for graduates to enter the formal wage sector, particularly in engineering or plumbing (Van de Grijp, 2002, 2003, 2005).

In response to the limited opportunities in Wallis and Futuna, many remain in the hinterland. In contrast to the literature, it cannot be said that there is a 'selection bias' where the destinations attract the 'best and brightest' through selective immigration policies as seen in the literature (Adams Jr, 2003; Kapur \& McHale, 2005), given the free movement association of Wallis and Futuna. Access to education here provides students with the opportunity to have qualifications that are recognised in France and the DOM COM, as opposed to some situations in the literature where unrecognised degrees lead to brain waste in the destination (Brown \& Connell, 2004). Many young people do settle permanently in the destination in order to exploit employment opportunities with higher wages and better security abroad, as seen in the literature (Kapur \& McHale, 2005). Participants also highlighted that Wallisians and Futunans have been able to fill some employment shortages in New Caledonia for instance. This is particularly similar to the findings of Brown and Connell (2004) where health workers were filling in for employment shortages in developed countries.

Benefits of education for Wallis and Futuna are further limited due to the lack of follow-up of young people leaving for education. The territory is unaware of the 
skills available in the hinterlands. For this reason, it is up to the graduate to return and make their qualifications known. Additionally, to find employment in the territory, timing is crucial because employment opportunities rarely become available. Many young people return for a certain period of time waiting for an opportunity to open up. In some cases, it was clear that skill was underused because of the lack of employment possibilities. Graduates may find themselves either unemployed or in jobs that are not suited to their skill level if they stay in the territory.

The loss of human capital is costly for the territory since the territorial budget heavily subsidises education. This was a particularly detrimental factor highlighted in the literature (Boulding, 1968; Brown \& Connell, 2004; Castles \& Miller, 2009; Kapur \& McHale, 2005). Connell (2008) emphasised that bonding contracts could ensure the return of skill and although findings in this research demonstrated that there were schemes to address this loss of capital through bonding contracts with the SITAS or 40 cadres, it did not guarantee return. For graduates who do not feel compelled to return won't return (Boulding, 1968). It could be argued that France and the DOM COM have benefited from education of migrants having been funded by Wallis and Futuna.

\section{2 .2 brain gain}

On the other hand, studies found that for migration to assist development, countries will first experience outmigration (Castles \& Miller, 2009; Fan \& Stark, 2003; Massey, 1988). This may in fact be occurring in Wallis and Futuna, as there is slow evidence of brain gain happening alongside the brain drain. However, the possible positive impacts of education in Wallis and Futuna may not yet be overtly evident since access to education is relatively recent and has been assisted by the introduction of grants in the last 15 years.

The literature saw brain drain as a catalyst for further education and potential development for sending countries (Fan \& Stark, 2003; Stark, 2004; Stark et al., 1997). The brain gain literature states that people should be provided with the 
tools to invest in their own education by offering the opportunity to migrate abroad (Adams Jr, 2003; Fan \& Stark, 2003; Kapur \& McHale, 2005; Mountford, 1997; Stark, 2004; Stark et al., 1997). Education and open borders would increase their chances of finding employment overseas but will also assure that a percentage of the educated stay at home (Fan \& Stark, 2003; Stark, 2004; Stark et al., 1997). This would in turn benefit the sending countries, the host countries and the migrants themselves (Fan \& Stark, 2003). Although, this concept does not exactly transfer to the context of this research since this theory would assume that people are able to acquire qualifications at home. Nevertheless, it could be argued that brain gain is occurring in a slightly different way.

Given that the employment pool is so narrow in Wallis and Futuna, employment opportunities are often advanced and require higher levels of education. This is true for teaching, medical professions, higher-level bureaucratic jobs and other specialised professions. The limited employment opportunities in Wallis and Futuna are prestigious and offer high wages and benefits. Opportunities for employment, with the added security of living at home, act as an important incentive for young students to pursue higher education. This finding would also then contradict the brain gain assumption that populations invest in education in order to improve their chances of finding more lucrative employment abroad. The legislations for equal opportunity have in a way acted as an impetus for brain gain but it is not only the prospects for employment abroad that is the drive for education, it is also the prospect of return. This was evident from the interviews since many returning Participants had chosen their subjects to increase their chances of employment in the territory. As a result, there has been evidence of positive returns from education.

The idea that the possibilities for return are providing an incentive for education could be backed up by the argument that the prestige of employment opportunities in Wallis and Futuna is a sign of success for graduates. Given that young people are no longer drawn to subsistence farming and are drawn to consumerist lifestyles, access to employment is necessary in order to live in the territory. A graduate who is employed and can afford to stay in the territory and 
support the extended family could be a sign of success, a sign of independence. This argument is contrary to Connell's $(1983 ; 1990 b)$ finding in Wallis and Futuna that stipulated return could be a sign of failure.

The structure of the French system has in a sense enabled Wallis and Futuna to have influence over the education of future returnees and have the possibility to introduce subjects at high school based on the employment opportunities in the territory. This continues to be done based on regular meetings in the territory. Additionally, access to grants and other education opportunities such as SITAS and 40 cadres provide additional assurance that students could return with the required degrees. While some Participants have argued that these training programmes have focused on public sector employment, it appears that more private sector workers have been benefiting from the programmes. The possibility to enforce targeted education could be further utilised to benefit the territory with an assessment of its own needs.

Additionally the 'turnover' argument by a few of the Participants has demonstrated that, through equal access to education, there have been a growing number of local professionals entering positions that used to be filled by metropolitan workers. According to Participants, an increasing number of returnees are entering the workforce because they have acquired the degrees required, particularly in the public sector. The process of localisation is additionally encouraging training through programmes highlighted above. There has also been evidence of graduates returning and starting private sector activities in the territory, which have in turn hired local graduates.

These characteristics are a clear sign that access to education has had a slow brain gain effect in Wallis and Futuna as students are increasing human capital and returning to access employment at home. However, this could only continue with an enabling system and determined graduates.

The above key findings have presented that Wallis and Futuna is simultaneously experiencing brain drain and brain gain as a result of the territory's use of their hinterlands. Brain gain has been occurring whereby the local population has 
been gaining access to higher positions through education in these hinterlands. And although the limited economic structures have restricted the return of these graduates and perpetuated the brain drain, access to the hinterlands has provided a 'safety valve' for these populations. The opportunity to migrate and settle in New Caledonia or France is an additional incentive that offsets the uncertainty of success in Wallis and Futuna. The incentives for education are that students have the option of returning to Wallis and Futuna but also have the safety of knowing there are opportunities in their destination. In that way, human capital for Wallis and Futuna (at home and abroad) should be increasing. Moreover, if it weren't for migration, education and the possibility of settlement in France, brain waste or educated unemployment in Wallis and Futuna would be much higher.

The role of Wallis and Futuna in this sense is difficult. Although there is evidence of return of some graduates, it is still limited. It is clear that many aspects of the system need to be addressed in terms of education, employment and creation of activity in the territory. It could be argued that young migrants are reacting not only to underdevelopment but also to the lack of possibilities for development and the lack of incentives to support economic activity in the territory.

The benefits of the brain gain are however further limited by the structures and attributed scarceness of productive resources. Returns and the benefits of return may in fact be constrained by the fear that return may have "disastrous effects" on the economic, social and political life of Wallis and Futuna, as Baudchon (1992, p. 347) had noted. In fact, the potentially 'disastrous effects' are being abated by societal management of education and other resources of the hinterland and will be discussed in the next section.

\subsection{Controlling the impact of education}

The dichotomy between a system of 'égalité, fraternité et liberté' and the Wallisian and Futunan socio-hierarchical system has created a disjointed interlocking system as opposed to a linear and unified structure. This 
interlocking stems from the statute of 1961 where crucial elements from two systems were merged to create a new one. As a result of this merging, as highlighted in the introduction, Wallis and Futuna has undergone a slow yet steady process of modernisation through the transfer of the French system of education, health services, infrastructure, television, among other modern commodities (Angleviel, 2004; Angleviel \& Papilio-Halagahu, 2014) and the islands have benefited from a relatively higher standard of living compared to surrounding island nations (Angleviel \& Papilio-Halagahu, 2014; van der Grijp, 2002). However, this process of modernisation within Wallis and Futuna has been a gradual partial transferral of the French system. Over time, Wallis and Futuna has gathered incompatible or incomplete elements of society from the French State, which have periodically disturbed the previous established local system. In the literature, it was evident that this process of modernisation in Wallis and Futuna and within the wider Pacific region has been accepted, in part particularly by youth, and particularly by elders (Angleviel, 2004; Connell, 2010; Likuvalu, 2004; Sharrod, 1993; Tafalagi, 2004). This divided view on change was evident in the findings and has had an important influence on the return of graduates.

The findings demonstrated that equal access to education and higher education through migration is an extension of this process of modernisation. Here, education is just another "general process of modernization" (Connell, 1983, p.23). Education and migration appear to have been seen as an opportunity for resource, but also as an added threat to the status quo. In fact, this slow change has been evident in the realm of education as up until only recently access to education was a privilege, not a right.

Connell (199ob, p.21) stated that migration was "a force of conservation and dissolution". The research mirrors this finding and it has been further reinforced by access to education. This was evident in the findings but the impact of education and migration is dependent on the way these concepts have been strategically used by authorities and individuals to 'benefit' society in different ways. 
On the one side it was evident that, due to the structure of the system, education and migration have been strategically used to reinforce Wallisian and Futunan sovereignty, customary authority and traditions. The evidence of uncoordinated combination of the two systems and the apparent failure to consolidate a cohesive linear structure has motivated continuous negotiation, particularly in terms of employment, between the customary powers, political powers and state administration in an effort to maintain stability within the territory.

As the French system is designed to assure uninterrupted compatibility where education and employment complement each other, the power to negotiate in Wallis and Futuna has interfered with this. Although the system of equal opportunity for education has been fully transferred to a certain extent, employment and development of activities are not essentially under the same conditions. In fact, return and possible employment in the territory is subjected to an additional selection process based on factors such as age, place in society, clan, networks, land ownership and village of origin.

In the literature, migration was seen as an opportunity for those who wanted to continue valuing culture and traditions to stay while those wanting to venture into modernity, to leave (Connell, 2010; Sharrod, 1993). In this context, education has in a way further provided an opportunity of 'conservation' or 'resurgence' (Connell, 199ob, 2010) of tradition since young people wanting to pursue education are helped in them leave the territory. Access to qualifications in this case provides them with greater access to the employment opportunities in their destination and returning graduates who do not fit the criteria are sent away. Customary land employment and pressure from customary authorities for employment are also significant examples of using education and migration as a conservation of customary structures. With customary land employment, graduates are discouraged from returning since employment may be reserved for often less qualified land owners, family members or village locals. Furthermore, qualifications are not significant for opportunities in political or customary positions of responsibility (élu, kings, and customary chiefs), which are still assigned based on lineage or customary representation within villages. 
Since the return of educated youth could be a disruptive element to the status quo, it could be argued that managing return has enabled local powers to maintain a certain control over the process of change and modernisation. Findings showed that this effort to maintain control over return is to avoid a loss of power or change to the overall hierarchical structure and loss of customary values but it is also attributed to a lack of communication and understanding of the need to develop and the need to modernise. In a similar way to Connell's (2010, p. 123-124) findings, the benefits to modern changes are not obvious for the older generations; rather they are subjected to a loss of power and representation in the process. In response, similar to the findings by Sharrod (1993, p.20-21), the system is encouraging young people to go somewhere "that makes them feel wanted" and where their place and status does not have an impact on their ability to fulfil their potential for success.

Additionally, where limiting return is not possible, the control of change is evident through the silencing of ideas. There was evidence that young returnees had conflicting ideas to those of the elders of society, as identified in the literature (Connell, 199ob, p. 17). From the findings, similar to the literature (van der Grijp, 2002), little legitimacy was given to those who threatened to challenge the established authorities. It could be argued that employment and ultimately development could be hindered, as the legitimacy of ideas or projects could be dependent on a person's place in society. People from a more dominant family may have more of a right to a voice and therefore would have more ease in introducing projects or ideas than someone from another background. Place and a person's right to speak determine the legitimacy of their ideas first, rather than education. This is even less recognised if the person returns papalagi, or 'acts western' as identified in the literature (Ritterbush \& Pearson, 1988 cited in Connell, 199ob).

Additionally, in the literature, knowledge transfers from migrants have been seen as crucial for the development of a country (Siar, 2012), but in Wallis and Futuna returnees are required to be mindful of the context in the territory and adapt the knowledge accordingly. 
On the other hand, although findings highlighted that employment may be reserved for the aliki families, there is evidence that this system has been changing with further transfer of the French system of equality of opportunity in employment. Since, some participants have insisted that custom, hierarchy and employment are completely separate entities and a person's place in society will not impact this person's ability to find employment.

In fact, it was evident from the findings that education and employment and the transfer of the French system have incurred some changes in the class structures and played a significant role in the weakening of the hierarchy. In conjunction with intermarriages between classes, the delimitations between noble, customary, higher classes and lower classes have been blurred. As qualifications become more recognised and are reinforced as a requirement, particularly in the bureaucratic sector, it seems that qualifications become an incentive for the higher classes to fulfil the requirements and find employment. Therefore, within the process of localisation in the territory, there has been a growing new higher class as a result of higher education, access to employment and high wages, a similar class to the 'bureaucratic class' identified by Watters (1987) in the MIRAB economies. These higher classes have been further reinforced by a system of networks and nepotism whereby the limited employment available is shared amongst a collection of families.

Participants did highlight that the system is changing as more people from less dominant families are entering the workforce, some emphasised that being a successful candidate did not automatically transfer into success at work. As demonstrated in the findings, successful candidates from 'lower' backgrounds found it difficult to assert their position because of their lack of 'voice'. Furthermore, it was highlighted that people from lower socioeconomic backgrounds may not be given priority and may not be successful in the jobs that they are qualified for.

Education is not the only factor driving emigration. Decisions to emigrate are influenced by other factors such as financial difficulties, customary 
responsibilities, etc., that draw migrants to the hinterland. The option to leave behind this pressure to give, share, and find ways to improve representation and presence in society may be attractive.

A new phenomenon highlighted by participants was the increasing number of graduates who are bringing family members to join them in the hinterlands. Education and migration is thus perpetuating the outmigration of the younger population but is also contributing to the outmigration of the rest of the population. Emigration for ageing parents of students is increasingly attractive because, abroad, they would have access to financial assistance, better healthcare and would no longer need to pay the expensive airfares to visit their children.

It could be argued that education may also be the solution to the problem. There is evidence that this system may be changing as qualifications become further recognised and required. As a reaction to the 'crowding out', determined youth return with a transformed understanding, an outside critique of the system and a new vision for the future. Those who succeed in the territory are able to assemble the old with the new and find employment or create activity within the confines of tradition.

\subsection{Conclusion}

As demonstrated in the findings, outmigration is an important concern in Wallis and Futuna. From the perspective of the brain drain literature, migration and education has had a negative impact on the future potential for economic development of Wallis and Futuna. On the other hand, Wallis and Futuna have shown signs of experiencing a gradual process of brain gain. Additionally, migration and education has provided a certain 'safety valve' not only in the sense of alleviating population, economic and employment pressures but also in terms of providing a gateway for modern youth to escape the cultural, customary and political moulds dictated by their place in society. 
Wallis and Futuna are going through a continuous process of transformation as a result of the interaction with the hinterland. It could be argued that the hinterlands (France, New Caledonia, etc.) are benefiting from the increased human capital at the expense of Wallis and Futuna, yet the territory has also proved to strategically use education to benefit the interests of different classes of society.

The findings presented that education and migration has simultaneously helped slow the process of change, increased access to employment at home and overseas, but has also helped transform society. The hinterland, through education, is providing a platform for crowding out and a resource for local progress and development. 


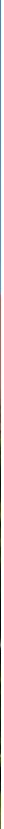

Chapter Six:

A new brain gain and a postMIRAB economy 
The impact of migration on development has been a central topic for debate on a global scale and within the Pacific. Recently, migration for education has been significantly high due to scarce higher education facilities in the region. Previous literature has demonstrated that migration to the peripheries and abroad for education has had different impacts on countries in the region depending on factors such as remittances, strength of networks, return, ease of migration to a developed centre, and structural factors at home. The absence of research on the relationship between migration and education and the impact of migration in the territory of Wallis and Futuna presented a significant gap and ultimate necessity for this study. Based on these gaps, the research set out to address the following question:

\section{What role does migration for education have within the MIRAB economy of Wallis and Futuna?}

Through Talanoa interviews, the research was able to uncover a multitude of realities and truths based on the interpretations of the participants. The grounded theory method has also enabled the research to gather new dimensions to existing literature and theories. In fact, it appears that migration from Wallis and Futuna is caught in a whirlwind of additional forces and factors (structural and cultural) that concurrently enable and inhibit the benefits of migration for the local populations in different ways - within which education has played a significant role.

The research has supported much of the existing brain drain literature and has illustrated many of the possible risks of accessing education abroad for sending countries. Nonetheless, the findings have also revealed the recent role of education as a catalyst and have new conclusions that complement and challenge existing literature. Three significant conclusions have arisen from this research:

A new dimension of the brain gain theory: return is an incentive to pursue higher education. 
As a result of high competition at home, Wallis and Futuna do not have a shortage of labour.

Education is a new component of the MIRAB structure and has brought about further social and cultural dimensions to the model.

The research demonstrated that, although Wallis and Futuna is experiencing high brain drain, this could be a response of the population to underdeveloped structures that hinder the use of qualifications in their home islands. There is evidence that, gradually, determined young graduates are returning and contributing to economic activity or entering public sector employment. Evidence of localisation has shown that return acts as an incentive to pursue higher education, adding a significant new dimension to the brain gain theory. MIRAB structures and the association with France have helped the brain gain since high wages, bureaucratic employment and requirement for higher education for employment act as a strong incentive to pursue education and return. As a result, there is high competition for employment in the territory, which contradicts much of the established brain drain research. Although activity still remains low for private sector employment and cultural factors sometimes have influence over who accesses the positions, determined returning graduates have started to challenge these systems.

The findings have brought to the forefront the destabilising nature of education to social, cultural and political factors in the territory, attributed to the contradicting ideals of 'tout le monde a sa place' (everyone has their place) and 'liberté, egalité and fraternité (freedom, equality and fraternity). In doing so, this research has brought to light the social and cultural dimensions of the MIRAB model - not previously covered in the existing literature.

The research has demonstrated that in a structure supported by migration remittances, aid and bureaucracy like Wallis and Futuna, education has had an important role in challenging the social orders of traditional society. The reliance on the bureaucracy as the main provider of employment and the limited opportunities available in other sectors (as is characteristic of MIRAB islands) 
paired with the increased access to education has created more competition for employment in the islands. This competition here has only reinforced a dissonance between the two systems: the French egalitarian system and the Wallisian and Futunan hierarchical system. As a result, limited employment available the selection process is not always fair and equal and the importance of hierarchy and education in this system are questioned. As a result, education and the MIRAB have blurred the lines between customary hierarchies and other social classes such as the bureaucracy. There appears to be a continuous challenge to find a place for education, employment whilst maintaining customary tradition.

Education as a catalyst however has only been enabled by the strategic use of the resources in the hinterland, as argued in the discussion, through young determined migrants acting as a medium for transformation. The return of graduates could be the driver of the cohesion between the two systems. Indeed, current elements within the system will continue to shift with the gradual return, with the implementation of new ideas and projects, and with the gradual changeovers of powers. It is crucial to acknowledge however that, as Skeldon (2008) highlights, migrants should not be given the sole responsibility of shaping development but they have significant power to challenge established structures. In fact, already, there has been evidence of the system slowly changing but in staggered increments.

In this case, the metaphor of the kaleidoscope (Bertram, 2006) represents the combination of two systems and perfectly illustrates how elements extracted from each system slowly emerge while others become less apparent to create a new pattern of the kaleidoscope or a new structure. In this research, education has been found to be a key piece of the kaleidoscope and, through migration, has been disruptive to the existing system whilst having the potential to drive Wallis and Futuna towards a new stability. Whether education and return will reinforce the MIRAB model or drive Wallis and Futuna into a post-MIRAB context is still difficult to predict. However, it can be assumed that Wallis and Futuna will always require the hinterlands, not only for resources but also as a welcoming 
space for populations who cannot or no longer want to live in Wallis and Futuna. The future shouldn't be looking towards changing the system, rather it is about bringing new coherence to the MIRAB economy where capitalism and custom work alongside each other as separate entities.

Connell (1983, p. 27) concluded that the 'viability' of the socio-economy of Wallis and Futuna 'is slowly being eroded', but from this study it appears that education has provided a new opportunity to reinstate and reconstruct this viability.

In fact, education is an inevitable variable, a new resource from the hinterland that is simultaneously perpetuating emigration and enabling return. Education has destabilised the MIRAB system in Wallis and Futuna whilst providing opportunities towards a new stability, a post-MIRAB system or a reinvigoration of the old MIRAB economy.

This research could provide a platform for a new research series pertaining to the role of education in other MIRAB or Pacific economies. Future research in this field should have particular focus on social and cultural transformations as a result of new education for migration patterns. 


\section{Bibliography}

Accord Particulier entre l'Etat, la Nouvelle-Caledonie et le Territoire des Iles Wallis et Futuna 1-4 (2003).

Adams Jr, R. H. (2003). International migration, remittances, and the brain drain: A study of 24 labor-exporting countries. World Bank Policy Research Working Paper(3069).

Adams, W., \& Douglas, P. H. (1968). The brain drain. New York: Macmillan

Agunias, D. R. (2006). From a Zero-Sum to a Win-Win Scenario? Literature Review on Circular Migration Washington, DC. : Migration Policy Institute.

Ahlburg, D. A., \& Brown, R. P. C. (1998). Migrant's intentions to return home and capital transfers : a study of Tongans and Samoans in Australia. The Journal of Development Studies, 35(2), 125-151.

Angleviel, F. (2004). What development for Wallis and Futuna. The Journal of Pacific Studies, 27(1), 83-94.

Angleviel, F., Agostini, T., Dupuy, F., \& Lavault, P. (1998). An island at the end of the world: Wallis. In C. Jost (Ed.), The French-speaking Pacific : population, environment, and development issues. Mount Nebo, Australia: Boombana Publications.

Angleviel, F., \& Papilio-Halagahu, B. (2014). Wallis et Futuna 3500 ans d'histoire Noumea: GRHOC

Appleyard, R. T. (1989). Migration and development: myths and reality. International migration review, 486-499. 
Bakewell, O. (2008). 'Keeping them in their place': the ambivalent relationship between development and migration in Africa. Third world quarterly, $29(7), 1341-1358$.

Baldacchino, G. (2006). Managing the hinterland beyond: Two ideal-type strategies of economic development for small island territories. Asia Pacific Viewpoint, 47(1), 45-6o.

Baudchon, G. P. (1992). Movement in the French Pacific: Recent Situation and Prospects. Asian and Pacific Migration Journal, 1(2), 333-349.

Beine, M., Docquier, F., \& Rapoport, H. (2008). Brain drain and human capital formation in developing countries: Winners and losers*. The Economic Journal, 118(528), 631-652.

Beine, M., Docquier, F., \& Schiff, M. (2008). Brain Drain and its Determinants: A Major Issue for small states. Bonn, Germany: Institute for the Study of Labor (IZA).

Benjamin, J. (1993). Opportunity and Migration in Micronesia. In G. McCall \& J. Connell (Eds.), A World Perspective on Pacific Islander Migration: Australia, New Zealand, and the USA (pp. 257-258). Australia: University of New South Wales.

Berger, P. L., \& Luckmann, T. (1967). The social construction of reality: a treatise in the sociology of knowledge. Harmondsworth: Penguin.

Bertram, G. (1986). Sustainable development in Pacific micro-economies. World Development, 14(7), 809-822.

Bertram, G. (1993). Sustainability, Aid, and Material Welfare in Small South Pacific Island Economies, 1900-90. World Development, 21(2), 247-258.

Bertram, G. (2006). Introduction: The MIRAB model in the twenty-first century. Asia Pacific Viewpoint, 47(1), 1-13. 
Bertram, G., \& Watters, R. (1985). The MIRAB economy in South Pacific microstates. Pacific viewpoint., 26(3), 497-519.

Bettis, L. (1993). Colonial Immigration on Guam. Displacement of Chamorro People Under U.S Governance. In G. McCall \& J. Connell (Eds.), A World Perspective on Pacific Islander Migration: Australia, New Zealand, and the USA (pp. 266-296). Australia University of New South Wales.

Bodvarsson, Ö. B., \& Van den Berg, H. (2009). The Determinants of International Migration: Theory. In Ö. B. Bodvarsson \& H. Van den Berg (Eds.), The Economics of Immigration: theory and policy (1st edition ed., pp. 27-57). New York Springer.

Boulding, K. E. (1968). The National Importance of Human Capital. In W. Adams (Ed.), The Brain Drain (pp. 109-119). New York: Macmillan.

Brikci, N., \& Green, J. (2007). A Guide To Using Qualitative Research Methodology In M. S. Frontiere (Ed.). London, Uk Medecins Sans Frontieres.

Brown, R., \& Connell, J. (2004). The migration of doctors and nurses from South Pacific Island nations. Social science and medicine, 58(11), 21932210.

Carling, J. (2008). Interrogating remittances: core questions for deeper insight and better policies. In S. Castles \& R. Delgado Wise (Eds.), Migration and Development: Perspectives from the South (pp. 43-64). Geneva: International Organization for Migration.

Cassarino, J.-P. (2004). Theorising return migration: The conceptual approach to return migrants revisited. International Journal on Multicultural Societies (IJMS), 6(2), 253-279. 
Castles, S., \& Miller, M. J. (2009). The age of migration : international population movements in the modern world (4th ed. ed.). New York: The Guildford Press.

Chacko, E. (2004). Positionality and Praxis: Fieldwork Experiences in Rural India. Singapore Journal of Tropical Geography, 25(1), 51-63. doi: 10.1111/j.0129-7619.2004.00172.X

Charmaz, K. (2006). Constructing grounded theory : a practical guide through qualitative analysis. London; Thousand Oaks, Calif.: Sage Publications.

Cohen, J. H., \& Sirkeci, I. (2011). Cultures of migration: The global nature of contemporary mobility. Austin, Texas: University of Texas Press.

Connell, J. (1983). Migration, employment and development in the South Pacific : Wallis and Futuna Islands. In J. Connell (Ed.), Migration, employment and development in the South Pacific Noumea, New Caledonia: South Pacific Commission

Connell, J. (1990a). Migration and development in the South Pacific. Canberra, Australia: National Centre for Development Studies, The Australian National University

Connell, J. (1990b). Modernity and its discontents: migration and change in the South Pacific. In J. Connell (Ed.), Migration and development in the South Pacific. (pp. 1-28). Canberra, Australia: National Centre for Development Studies, The Australian National University.

Connell, J. (2003). Island dreaming: the contemplation of Polynesian paradise. Journal of Historical Geography, 29(4), 554-581.

Connell, J. (2007). Islands, idylls and the detours of development. Singapore Journal of Tropical Geography, 28(2), 116-135.

Connell, J. (2008). Niue: Embracing a Culture of Migration. Journal of Ethnic and Migration Studies, 34(6), 1021-1040. 
Connell, J. (2010). Pacific islands in the global economy: Paradoxes of migration and culture. Singapore Journal of Tropical Geography, 31(1), 115-129.

Cour des comptes. (2010). Rapport public annuel: Le coût disproportionné de certaines niches fiscales en Nouvelle Calédonie et à Wallis et Futuna. Paris, France.

Creswell, J. (2013). Research Design: Qualitative, Quantitative, and Mixed Methods Approaches (Fourth Edition ed.). London, UK SAGE.

CROUS Paris. (2016). Bourses sur criteres sociaux Retrieved 26/o2/2016, 2016, from http://www.crous-paris.fr/bourses/bourses-sur-criteres-sociaux/

De Haas, H. (2012). The migration and development pendulum: A critical view on research and policy. International Migration, 50(3), 8-25.

de la Croix, D., Docquier, F., \& Schiff, M. (2014). Brain Drain and Economic Performance in Small Island Developing States The Socio-Economic Impact of Migration Flows (pp. 123-144): Springer.

de Deckker, P. (1998). Uvea-Wallis: une identite mouvementee. In D. T. Tryon \& P. de Deckker (Eds.), Identités en mutation dans le Pacifique à l'aube du troisième millénaire (pp. 46-56). Talence, France: Centre de recherches sur les espaces tropicaux de l'Université Michel de Montaigne-Bordeaux.

Deshingkar, P., \& Grimm, S. (2005). Internal migration and development: a global perspective. Geneva, Switzerland: International Organization for Migration (IOM).

Docquier, F., \& Rapoport, H. (2004). Skilled migration : the perspective of developing countries. In B. World (Ed.), (pp. 1-38). Washington, D.C.: World Bank.

Docquier, F., \& Schiff, M. (2009). Measuring skilled migration rates: The case of small states World Bank Policy Research Working Paper Series. Washington D.C.: World Bank 
Faini, R. (2007). Remittances and the Brain Drain: Do more skilled migrants remit more? The World Bank Economic Review, 21(2), 177-191.

Fairbairn-Dunlop, P. (1993). A Positive Response to Migration constraints. In G. McCall \& J. Connell (Eds.), A World Perspective on Pacific Islander Migration: Australia, New Zealand, and the USA (pp. 327-342). Australia: University of New South Wales.

Fairbairn-Dunlop, P., \& Coxon, E. (2014). Talanoa : building a Pasifika research culture. Auckland, N.Z.: Dunmore Publishing.

Fairbairn, T. o. I. J. (1993). Remittance Income : Its importance for some Pacific Island Countries and Implications for Production In G. McCall \& J. Connell (Eds.), A World Perspective on Pacific Islander Migration: Australia, New Zealand, and the USA (pp. 311-318). Australia: University of New South Wales.

Fan, C. S., \& Stark, O. (2003). Addition through Depletion: The Brain Drain as Catalyst of Human Capital Formation and Economic Betterment: University of Klagenfurt, Klagenfurt.

Farelly, T., \& Nababa-Bobo, U. (2012). Talanoa as empathic research. Paper presented at the International Development Conference Auckland University, NZ.

Ferrante, P. (2015, 02/11/2015). Fin du nouveau conflit au lycée de Wallis et Futuna, Wallis et Futuna 1ere. Retrieved from http://wallisfutuna.la1ere.fr/2015/11/o2/fin-du-nouveau-conflit-au-lyceede-wallis-et-futuna-301119.html

Finau, M., Drouet-Manufekai, M. S., Falelavaki, M. L., Beauvilain, T., Pantz, P.A., \& Nicomette, P. (2009). Tavaka lanu 'imoana : mémoires de voyages. Noumea, New Caledonia: Agence De Développement De La Culture Kanak, Centre Culturel Tjibaou. 
Finau SM, P. P. (1993). How Immigration Affects the Home Country In G. McCall \& J. Connell (Eds.), A World Perspective on Pacific Islander Migration: Australia, New Zealand, and the USA (pp. 307-310). Australia: University of New South Wales.

Findlay, A. M. (2002). From brain exchange to brain gain : policy implications for the UK of recent trends in skilled migration from developing countries. Geneva, Switzerland: ILO.

Firth, S. (2006). Globalisation and governance in the Pacific Islands. Canberra, Australia ANU E-Press.

Gamlen, A. (2010). The new migration and development optimism: A review of the 2009 Human Development Report. Global Governance: A Review of Multilateralism and International Organizations, 16(3), 415-422.

Gamlen, A. (2014). The new migration-and-development pessimism. Progress in Human Geography, 38(4), 581-597.

GCIM. (2005). Migration in an interconnected world: new directions for action. Switzerland: Global Commission on International Migration (GCIM).

Gibson, J., \& McKenzie, D. (2011). The microeconomic determinants of emigration and return migration of the best and brightest: Evidence from the Pacific. Journal of development economics, 95(1), 18-29.

Gibson, J., \& McKenzie, D. (2012). The Economic Consequences of 'Brain Drain'of the Best and Brightest: Microeconomic Evidence from Five Countries*. The Economic Journal, 122(56o), 339-375.

Halapua, S. (2000). Talanoa process: The case of Fiji. from http://unpanı.un.org/intradoc/groups/public/documents/un/unpano22 610.pdf 
Hau'ofa, E. (2008). Our Sea of Islands. In E. Hau'ofa (Ed.), We are the ocean selected works (pp. 27-40). Honolulu: University of Hawaii Press.

Huffer, E., Leleivai, P., \& Sanchez, C. (2001). Futuna : mo ona puleaga sau = aux deux royaumes $=$ the two kingdoms. Suva, Fiji; Sigave, Futuna: Institute of Pacific Studies ; Service des affaires culturelles de Futuna.

IEOM. (2015). Wallis-et-Futuna Rapport Annuel 2014. Noumea, New Caledonia: Institut d'Emission d'Outre-Mer.

INSEE. (2009). Wallis et Futuna : Recensement de la population de 2008: 10\% d'habitants en moins depuis 2003 (pp. 1-4). Paris, France Institut National de la Statistique et des Etudes Economiques.

INSEE. (2014). Wallis et Futuna a perdu pres du cinquieme de sa population en dix ans (pp. 1-4). Paris Institut National de la Statistique et des etudes economiques.

IOM. (2005). International Dialogue on Migration: Mainstreaming Migration Into Development Policy Agendas. In I. Pinto-Dobernig (Ed.). Geneva: International Organization for Migration.

James, K. E. (1993). Cash and Kin. Aspects of Migration and Remittances from the Perspective of a Fishing village in Vava'u, Tonga. In G. McCall \& J. Connell (Eds.), A World Perspective on Pacific Islander Migration: Australia, New Zealand, and the USA (pp. 359-374). Australia: University of New South Wales.

Kapur, D. (2004). Remittances : the new development mantra? United Nations Conference on Trade and Development: G-24 Discussion Paper Series. New York; Geneva: United Nations.

Kapur, D., \& McHale, J. (2005). Give us your best and brightest : the global hunt for talent and its impact on the developing world. Washington, D.C.: Center for Global Development. 
Katseli, L. T., Lucas, R. E., \& Xenogiani, T. (2006). Effects of Migration on Sending Countries: what do we know? Turin, Italy: OECD Development Centre.

Kindleberger, C. (1968). Study abroad and emigration. In W. Adams \& P. H. Douglas (Eds.), The brain drain (pp. 135-155). New York: Macmillan.

LADOM. (2016). Passeport Mobilite-Etude. Retrieved 26/02/2016, from http://pme.ladom.fr/

Lataste, R. (2015, 27/11/2015). Conflit aéroport: Wallis et Futuna de plus en plus isolés, Wallis et Futuna 1ere. Retrieved from http://wallisfutuna.la1ere.fr/2015/11/27/wallis-et-futuna-de-plus-en-plusisoles-309987.html

Likuvalu, A. (2004). Education in Uvea: Tradition, Mission and Republic. In F. A. Talatini, E. Huffer \& M. Tui (Eds.), Uvea (pp. 127 -133). Suva, Fiji: Institute of Pacific Studies, University of the South Pacific.

Loi n 61-814 du 29 juillet 1961 conférant aux îles Wallis et Futuna le statut de territoire d'outre-mer (1) Prefecture des Iles Wallis et FUutna Pub. L. No. 61-814 (2012).

Loomis, T. (1990). Remittances and Development: Cook Islands Migrants in New Zealand and Their Influence on Cook Islands Development. In J. Connell (Ed.), Migration and Development in the South Pacific (pp. 6181). Canberra, Australia National Centre for Development Studies, The Australian National University

Maclellan, N., \& Mares, P. (2006). Labour Mobility in the Pacific: Creating seasonal work programs in Australia In S. Firth (Ed.), Globalisation and governance in the Pacific Islands (pp. 137-171). Canberra: ANU E Press.

Malau, A. (2004). Culture and agriculture. In F. A. Talatini \& N. Carruthers (Eds.), Uvea (pp. 165-191). Suva, Fiji; Mata'utu, Wallis: The University. 
Malau, A., Takasi, A., \& Angleviel, F. (1999). Wallis et Futuna. Nouméa: Ile de lumière.

Massey, D. S. (1988). Economic development and international migration in comparative perspective. The Population and Development Review, 14(3), $383-413$.

Massey, D. S., Arango, J., Hugo, G., Kouaouci, A., Pellegrino, A., \& Taylor, J. E. (1993). Theories of international migration: a review and appraisal. Population and Development Review, 19(3), 431-466.

Migaud, D. (2014). La situation du territoire des iles Wallis et Futuna (pp. 1-5). Cour des comptes: Cour des comptes.

Morton, K. L. (1987). The atomization of Tongan society. Pacific Studies, 1o(2), 47-72.

Mountford, A. (1997). Can a brain drain be good for growth in the source economy? Journal of development economics, 53(2), 287-303.

Munck, R. (2009). Introduction. In R. Munck (Ed.), Globalisation and migration : new issues, new politics. London; New York: Routledge.

Niimi, Y., Ozden, C., \& Schiff, M. (2010). Remittances and the brain drain: skilled migrants do remit less Annals of Economics and Statistics/Annales d'Économie et de Statistique. Bonn, Germany Institute for the Study of Labor (IZA).

OECD. (2008). Part III: Return Migration: A New Perspective. In J. Dumont \& G. Spielvogel (Eds.), International Migration Outlook. Paris: OECD.

ONISEP. (2016). Apres le Bac: choisir ses etudes superieures Retrieved 29/02/2016, 2016, from http://fr.calameo.com/read/000037547fog2d5292a4b 
Overton, J. (1993). Small states, big issues? : Human geography in the Pacific Islands. Singapore Journal of Tropical Geography, 49(2), 48-55.

Poirine, B. (1993). Le développement par la rente dans les petites économies insulaires. Revue économique, 44(6), 1169-1199.

Poirine, B. (1994). Rent, emigration and unemployment in small islands: The MIRAB model and the French overseas departments and territories. World Development, 22(12), 1997-2009.

Poirine, B. (1998). Should we hate or love Mirab? The contemporary Pacific(1), 65-105.

Portes, A. (2008). Migration and development: A conceptual review of the evidence. In S. Castles \& R. Delgado Wise (Eds.), Migration and Development: Perspectives from the South (pp. 17-41). Geneva: International Organization for Migration

Prefecture des Isle Wallis et Futuna. (2016). La bourse territoriale sur criteres sociaux from http://www.wallis-et-futuna.pref.gouv.fr/Vosdemarches/Dossiers-de-Bourse

Rallu, J.-L. (1982). Les Wallisiens a Wallis et Futuna et en Nouvelle Caledonie. Population, 37(1), 167-175.

Rallu, J.-L. (1994). Tendances récentes des migrations dans le Pacifique Sud. Espace, populations, societes, 12(2), 201-212.

Reddy, M., Mohanty, M., \& Naidu, V. (2004). Economic cost of human capital loss from Fiji : implications for sustainable development. International migration review(148), 1447-1461.

Roux, J.-C. (1985). Un exemple de migration enracinement dans le Pacifique Sud : la communauté wallisienne et futunienne de Nouvelle-Calédonie. Cahiers ORSTOM.Série Sciences Humaines, 21(4), 461-48o. 
Roux, J.-C. (1995). Wallis et Futuna espaces et temps recomposés : chroniques d'une micro-insularité. Centre de recherche sur les espaces tropicaux, Talence (33405 Cedex).

Ruhs, M. (2006). The potential of temporary migration programmes in future international migration policy. International Labour Review, 145(1-2), 736.

Schevens, R., \& Mclennan, S. (2014). Introduction In R. Scheyvens (Ed.), Development Fieldwork (2nd Edition ed.). London: Sage.

Scheyvens, H., Scheyvens, R., \& Nowak, B. (2014). Personal Issues. In R. Scheyvens (Ed.), Development fieldwork : a practical guide (2nd edition ed.). London: London SAGE Publications Ltd.

Schiff, M. (2005). Brain gain: claims about its size and impact on welfare and growth are greatly exaggerated (Vol. 1599): World Bank Publications.

Sharrod, P. (1993). Questioning "Development". An Issue Behind the Issues. In G. McCall \& J. Connell (Eds.), A World Perspective on Pacific Islander Migration: Australia, New Zealand, and the USA (pp. 19-21). Australia University of New South Wales.

Siar, S. V. (2012). Skilled migration, knowledge transfer and development: The case of the highly skilled Filipino migrants in New Zealand and Australia. Journal of Current Southeast Asian Affairs, 30(3), 61-94.

Skeldon, R. (1997). Migration and development : a global perspective. Harlow: Longman.

Skeldon, R. (2008). International Migration as a Tool in Development Policy: A Passing Phase? Population and Development Review, 34(1), 1-18. doi: 10.1111/j.1728-4457.2008.00203.X 
Smith, M. P., \& Favell, A. (2006). The human face of global mobility : international highly skilled migration in Europe, North America and the Asia-Pacific. New Brunswick, N.J.: Transaction Publishers.

Stark, O. (2004). Rethinking the brain drain. World Development, 32(1), 15-22.

Stark, O., Helmenstein, C., \& Prskawetz, A. (1997). A brain gain with a brain drain. Economics letters, 55(2), 227-234.

Stark, O., \& Wang, Y. (2002). Inducing human capital formation : migration as a substitute for subsidies. Journal of Public Economics(86), 29-46.

Stewart-Withers, R., Banks, G., McGregor, A., \& Meo-Sewabu, L. (2014).

Qualitative Research. In R. Scheyvens (Ed.), Development Fieldwork (2nd Edition ed.). London: Sage.

Tafalagi, V. (2004). Discussing Aga'i fenua or Custom in Uvea. In F. A. Talatini \& N. Carruthers (Eds.), Uvea (pp. 134 - 144). Suva, Fiji; Mata'utu, Wallis: The University.

Thodock, C. (2007). Aid, remittances and the informal economy of Pacific Islands: a development governance perspective. In B. C. Prasad \& K. C. Roy (Eds.), Development problems and prospects in Pacific Islands states (pp. 71- 9o). New York: Nova Science Publishers.

Urquhart, C. (2013). Grounded theory for qualitative research : a practical guide. Los Angeles, Calif.; London: SAGE.

Vaioleti, T. M. (2006). Talanoa research methodology: a developing position on pacific research. Waikato Journal of Education(12), 21 - 34.

Vakala. (2008, 13/02/2008). 520 Boursiers de Wallis et Futuna preparent la rentree Retrieved 27/02/2016, from http://www.vakala.net/page-actuarticle-1228.htm 
van der Grijp, P. (2002). Selling is poverty, buying a shame : representations of work, effective leadership and market failures on Wallis. Oceania, 73(1), 17-34.

van der Grijp, P. (2003). Between gifts and commodities: Commercial enterprise and the trader's dilemma on Wallis ('Uvea). The Contemporary Pacific, 15(2), 277-307.

van der Grijp, P. (2005). Development polynesian style : contemporary Futunan social economy and its cultural features. The journal of the Polynesian Society, 114(4), 311-338.

Vertovec, S. (2006). Is circular migration the way forward in global policy?

Vidal, J.-P. (1998). The effect of emigration on human capital formation. Journal of Population Economics, 11(4), 589-6oo.

Watters, R. (1987). Mirab Societies and Bureaucratic Elites In A. Hooper (Ed.), Class and culture in the South Pacific (pp. 32 - 54). [Suva, Fiji]: Centre for Pacific Studies, University of Auckland, and Institute of Pacific Studies, University of the South Pacific.

Williams, A. M., \& Baláz, V. (2008). International migration and knowledge. London; New York: Routledge.

Willis, J., Jost, M., \& Nilakanta, R. (2007). Foundations of qualitative research : interpretive and critical approaches. Thousand Oaks: SAGE Publications.

World Bank. (2003). Chapter 7-Global Development Finance 2003: Striving for Stability Washington, D.C: Development Finance

Zimmer, L. J. (1990). When tomorrow comes: Future opportunities and current investment patters in an area of high out-migration In J. Connell (Ed.), Migration and development in the South Pacific (pp. 83-96). Canberra, Australia: National Centre for Development Studies Research School of Pacific Studies The Australian National University. 


\section{Appendices}

\section{Appendix A}

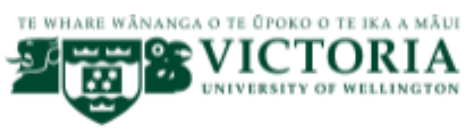

Participant Consent Form

Research Project Title: The effects of youth migration for education on the potential for development in Wallis and Futuna

Researcher: Alice Jacobs, School of Geography, Environment and Earth Sciences, Victoria University of Wellington, New Zealand.

1. I have been given and have understood an explanation of this research project. I have had an opportunity to ask questions and have them answered to my satisfaction.

2. I understand that I may withdraw myself (or any information I have provided) from this project, without having to give reasons, by e-mailing jacobsalic@vuw.ac.nz by the $31 / 09 / 2015$.

3. I understand that any information I provide will be kept confidential to the researcher and their supervisor, the published results will not use my name, and that no opinions will be attributed to me in any way that will identify me. I understand that I may, however, be referred to through the group or organisation of which I am a member.

4. I understand that the data I provide will not be used for any other purpose or released to others.

5. I understand that, if this interview is audio recorded, the recording and transcripts of the interviews will be erased immediately after the conclusion of the research. I will also have an opportunity to check the summary of the interview.

Please indicate (by ticking the boxes below) which of the following apply:

$\square \quad$ I would like to receive a summary of the results of this research when it is completed.

$\square \quad$ I agree to this interview being audio recorded.

$\square \quad$ I agree to be referred to by role or association with my organisation

\begin{tabular}{|l|l|}
\hline Signed: & Signed: \\
Name of Participant: & Name of Researcher: \\
Date: & Date: \\
\hline
\end{tabular}




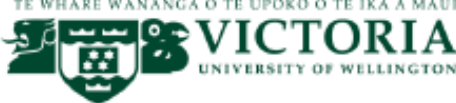

\section{Formulaire de Recueil de consentement Participation à une recherche}

Titre du projet de recherche: Les effets de la migration des jeunes pour l'éducation sur le potentiel de développement de Wallis et Futuna.

Chercheuse: Alice Jacobs, School of Geography, Environment and Earth Sciences (Ecole de Geographie, de l'environment et des sciences de la Terre), Victoria University of Wellington, Nouvelle Zélande

1. J'ai reçu et j'ai compris l'explication de ce projet de recherche. J'ai aussi eu l'opportunité de poser des questions et je suis satisfait(e) avec les réponses.

2. Je comprends que je peux me retirer (et toutes informations fournies) du projet, sans donner de raisons, en envoyant un courriel à alice.jacobs@vuw.ac.nz avant le $31 / 07 / 2015$.

3. Je comprends que toutes informations que je fournis sera gardées confidentiellement et ne sera qu'à la disposition de la chercheuse et de son superviseur. Les résultats publiés ne contiendront pas mon nom ni des attributs qui puissent dévoiler mon identité. Je comprends que je pourrai cependant être référé(e) par l'organisation auquel je fais parti.

4. Je comprends que l'information que je fournis ne sera pas utilisé pour d'autres recherches et ne sera accessible qu'à la chercheuse et son superviseur.

5. Je comprends que si cet entretien est enregistré, les enregistrements et les transcrits des entretiens seront détruits un an après la fin du projet. Je sais que j'aurai aussi l'occasion de vérifier un résumé de l'entretien.

Cochez les cases qui vous conviennent:

$\square \quad$ Je voudrai recevoir un résumé des résultats une fois que la recherche soit terminée.

$\square$ J'accepte que cet entretien soit enregistré

$\square$ J'accepte que je sois désigné comme étant attaché à l'organisation/l'université/l'école auquel je fais parti.

Signé:
Nom du participant:
Date:




\section{VIOFICTORIA}

Formulaire de Recueil de consentement

Participation à une recherche: Groupe de discussion

Titre du projet de recherche: Les effets de la migration des jeunes pour l'éducation sur le potentiel de développement de Wallis et Futuna.

Chercheuse: Alice Jacobs, School of Geography, Environment and Earth Sciences (Ecole de Geographie, de l'environment et des sciences de la Terre), Victoria University of Wellington, Nouvelle Zélande

1. J'ai reçu et j'ai compris l'explication de ce projet de recherche. J'ai aussi eu l'opportunité de poser des questions et je suis satisfait avec les réponses.

2. Je comprends que je peux me retirer (et toute information fournie) du projet, sans donner de raisons, en envoyant un courriel à alice.jacobs@vuw.ac.nz avant le $31 / 07 / 2015$.

3. Je comprends que toute information que je fournis sera gardée confidentiellement et ne sera qu'à la disposition de la chercheuse et de son superviseur. Les résultats publiés ne contiendront pas mon nom ni des attributs qui puissent dévoiler mon identité. Je comprends que je pourrais cependant être référé par l'organisation auquel je fais parti(e).

4. Je comprends que l'information que je fournis ne sera pas utilisé pour d'autres recherches et ne sera accessible qu'à la chercheuse et son superviseur.

5. Je comprends que si cet entretien est enregistré, les enregistrements et les transcrits des entretiens seront détruits un an après la fin du projet. Je sais que j'aurai aussi l'occasion de vérifier un résumé de l'entretien.

Cochez les cases qui vous conviennent:

$\square$ Je voudrais recevoir un résumé des résultats une fois que la recherche soit terminée.

$\square$ J'accepte que cet entretien soit enregistré

J'accepte que je soit désigné comme étant attaché à l'organisation/l'université/ l'école auquel je fait parti.

$\square \quad$ Je m'engage à tenir confidentielle toute information portée à ma connaissance du fait de ma participation à cette discussion.

Signé:

Nom du participant:

Date: 


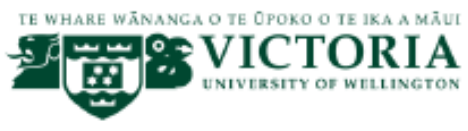

\section{Focus Group Consent Form}

Research Project Title: The effects of youth migration for education on the potential for development in Wallis and Futuna

Researcher: Alice Jacobs, School of Geography, Environment and Earth Sciences, Victoria University of Wellington, New Zealand.

1. I have been given and have understood an explanation of this research project. I have had an opportunity to ask questions and have them answered to my satisfaction.

2. I understand that I may withdraw myself (or any information I have provided) from this project, without having to give reasons, by e-mailing alice.jacobs@vuw.ac.nz by the $31 / 09 / 2015$.

3. I understand that any information I provide will be kept confidential to the researcher and their supervisor, the published results will not use my name, and that no opinions will be attributed to me in any way that will identify me. I understand that I may, however, be referred to through the group or organisation of which I am a member.

4. I understand that the data I provide will not be used for any other purpose or released to others.

5. I understand that, if this focus is audio recorded, the recording and transcripts of the interviews will be erased immediately after the conclusion of the research. I will also have an opportunity to check the summary of the interview.

Please indicate (by ticking the boxes below) which of the following apply.

$\square \quad$ I would like to receive a summary of the results of this research when it is completed.

$\square \quad$ I agree to this interview being audio recorded.

$\square \quad$ I agree to be referred to by role or association with my organisation

$\square \quad$ I agree to keep information gathered in this focus group confidential and not repeat it outside of this group.

Signed:
Name of Participant:
Date:




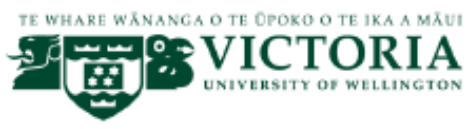

\section{Lettre d'information pour les participants}

Titre du projet de recherche: Les effets de la migration pour l'éducation des jeunes sur la capacité de développement de Wallis et Futuna.

Chercheuse: Alice Jacobs, School of Geography, Environment and Earth Sciences (Ecole de Géographie, de l'environnement et des sciences de la Terre), Victoria University of Wellington, Nouvelle Zélande

Cette étude fait partie d'un Master de Développement à l'université de Victoria à Wellington en Nouvelle Zélande. Cette recherche est destinée à étudier le mouvement migratoire des jeunes de Wallis et Futuna qui partent pour poursuivre une éducation supérieure au baccalauréat à l'étranger. Cette recherche nous permettra d'identifier les effets de ce phénomène sur le potentiel de développement du territoire. Comme le requière l'université, cette recherche a été acceptée par le comité d'étique de l'école.

Pour cette recherche, je demande la participation à des fonctionnaires humanitaires, des fonctionnaires du gouvernement, des professeurs et des étudiants. Les volontaires seront demandés d'assister dans des entretiens individuels ou en groupe d'une heure au maximum. C'est au choix des volontaires si les entretiens sont enregistrés.

La participation dans cette recherche est volontaire et les participants ne pourront pas être identifiés personnellement dans des rapports écrits publiés en conséquence de cette recherche. Les participants pourront cependant être désigné comme étant attaché à l'organisation ou l'école auquel il/elle en fait parti. Toutes documentations rassemblées seront gardées comme information confidentielle et ne sera qu'à la disposition de moi-même et mon superviseur John Overton. La thèse sera examinée par l'université et déposée dans la bibliothèque de l'université. En cas de publications ou conférences, les participants seront informés.

Si il ou elle le souhaite, le participant peut se retirer du projet avant le 30 Septembre 2015 et toute documentation récoltée jusqu'à ce point sera détruite. Toute documentation sera détruite un an après la fin du projet.

Si vous avez des questions ou souhaitez recevoir plus d'information sur le projet, n'hésitez pas a me contacter par email ou par téléphone souhaitez contacter mon superviseur vous pouvez par email téléphone

Alice Jacobs 


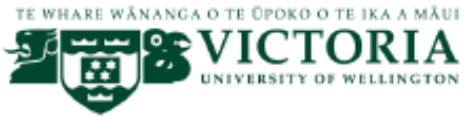

\section{Participant Information Sheet}

Research Project Title: The effects of youth migration for education on the potential for development in Wallis and Futuna.

Researcher: Alice Jacobs, School of Geography, Environment and Earth Sciences, Victoria University of Wellington

This study is a partial requirement for the completion of my Masters of Development Studies. The purpose of this research is to explore the migration of young people for education to New Caledonia or France and to discover how this phenomenon may affect the potential for Wallis and Futuna to develop.

Victoria University requires, and has granted, approval from the School's Human Ethics Committee.

I am inviting aid officials, Government officials, School professors, University students and School students to participate in this study. Participants will be asked to take part in an hour interview (approximately). Permission will be asked to record the interview.

Participation is voluntary, and you will not be identified personally in any written report produced and/or published in academic conferences and journals as a result of this research. You may, however, be referred to as an employee or student of your particular organisation or school. All material collected will be kept confidential, and will be viewed only by myself and my supervisor John Overton. The thesis will be submitted for marking to the University, and subsequently deposited in the University Library. The participants will be notified if there are publications or conferences as a result of the research.

Should any participant wish to withdraw from the project, they may do so until the $31 / 09 / 2015$, and the data collected up to that point will be destroyed. All data collected from participants will be destroyed within 1 year after the completion of the project.

If you have any questions or would like to receive further information about the project, please contact me at or by telephone or you may contact my supervisor John Overton at or telephone

Alice Jacobs 